Historic, Archive Document

Do not assume content reflects current scientific knowledge, policies, or practices. 



\section{LAWN SUPPLIES}

To make a Lawn: first, prepare the soil, which should be a good loam at least a foot deep, by digging, fertilizing and raking. Reduce the top layer or seed bed to the finest possible condition, free of stomes, sticks, hard clods, ete.

Second, sow the seed on a still day. To get a thick, velvety lawn plenty of seed must be used. A pound to 200 square feet is our recommendation. After seed is som, rake it in rery lightly-just barely covering the seed. Then roll. Constant rolling is necessary to maintain a good lawn.

\section{“A. S.\& L." EXT.RA FINE LAWN SEED}

This is a mixture of low growing grasses especially adapted to making a fine carpet-like lawn. We take great pride in the quality of our A. S. \& L. Lawn seed as we use only the best solid seed obtainable, without chaff or "filler" of any kind. We know that you will be pleased with this seed.

Price 50c. per pound. By mail add postage.

\section{'A. S. \& L." "SHADY PLACE'” IMIXTURE}

This is a mixture of extra fine Grasses adapted for growing in the shade and under trees. We recommend the use of this mixture wherever other grasses on account of shade have failed to make a close swark. Sow at the rate of $1 \mathrm{lb}$. per each $200 \mathrm{sq}$. ft. for a new lawn, or about half that quanticy for renovating existing turf.

Price 50c. per pound. By mail add postage.

\section{PALISADE RUBBER GARDEN HOSE}

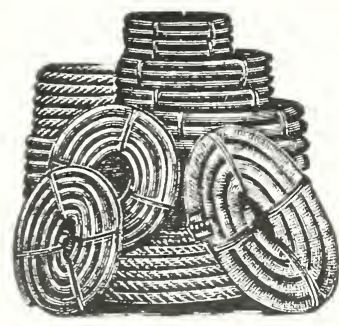

An extra durable garden hose of the same construction as a cord automobile tire. Absolutely guaran teerl to give satisfaction.

1. inch .... 16c. foot $\therefore$ incl ... 17 e. foot 3 inch .... Ise. foot

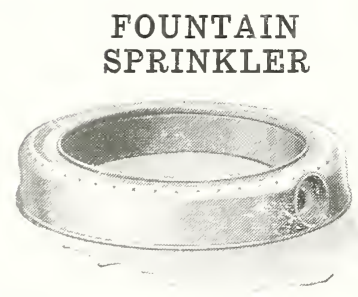

Price 8.5c.

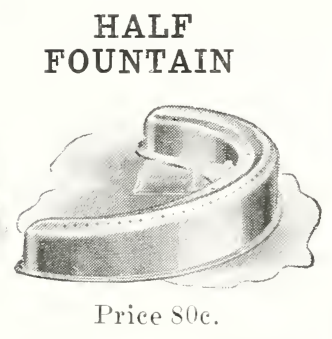

WHEEL BARROWS

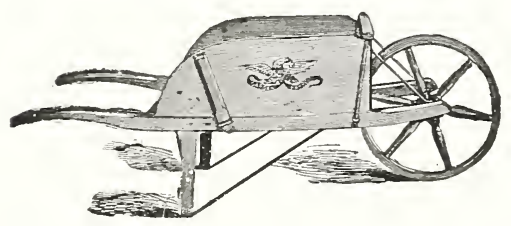

A. S. L. Garden. This Barrow is made from the best seasoned timber. The end of the bottom is cut into the back sill, thus preventing the splitting or breaking of the bottom boards. The wheel has a cast iron hub with white oak or ash spokes and rins. The axle is wrought iron, with turned arbors.

No. 4, price \$\$.00. No. 5, price \$\$.50.

\section{WATERING POTS}

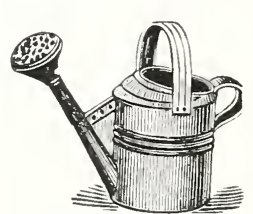

4 quart galvanized iron, $\$ . \rightarrow 0$ 6 quart galranized iron, ..5.5 - quart galranized iron, 1.00 10 quart galvanized iron, 1.15 12 quart galranized iron, 1.50 16 quart galranized iron, 1.75 20 quart galvanized iron, 2.25

\section{IMARCH Automatic RAINMAKERS}

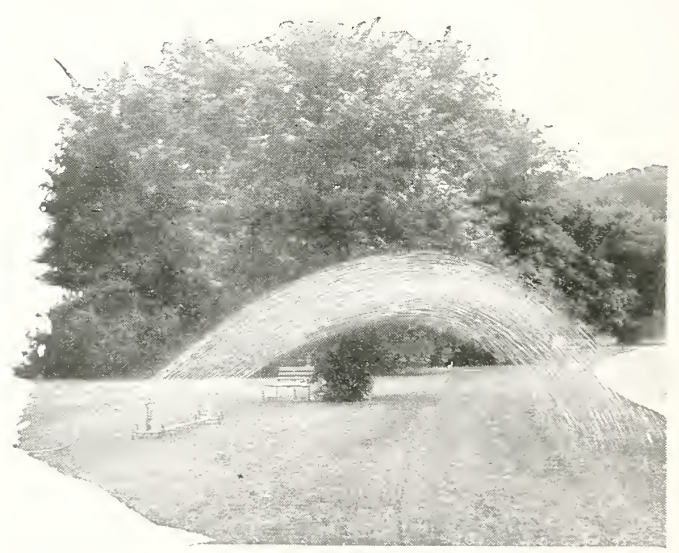

Sprinkles rectangles, not circles. Covers large areas rapidy without overlapping, and is quickly adjusted to water small spaces. Sprinkles along edge of walks or drives without wetting them. Ordinary water pressure from lawn hose turns the pipe line of nozzles as an axis, throwing the streams of water from one side orer to the other with a constant steady swing. Thousands in use on eitr lawns, large estates, golf courses, cemeteries, and parks.

MADE IN FOCR SIZES-WATERING FROM 1200 to 3000 SQUARE FEET AT A SETTIXG. Write for prices and literature. 


\title{
1927 Catalogue of "Sterling Quality" Seeds \\ (Garden, Field, Flower and Lawn)
}

\author{
also Barn Equipment, Separators, Sprayers, \\ Insecticides, Farm and Garden Tools, Dairy \\ and Poultry Supplies, Plants, Bulbs, \\ Fertilizers, Etc.
}

\section{Our Cover}

In a secluded little spot in beautiful Cape Elizabeth stands the buildings you see on our cover page. They are owned and occupied by Mr. Charles C. Jordan who was born there seventy-two years ago. His mother was also born in the same house.

About one hundred and sixty-five years ago, Samuel Waterhouse built the house; it is most interesting with the old-fashioned beams, closets, hand wrought hinges, door latches and pieces of old-fashioned furniture. The stones laid to the approach of the barn will weigh six or seven tons and must have required several yoke of oxen to haul.

Each year many people find their way to this alluring place, known as Sweet Brier Farm, with its fine shade trees and the old-fashioned well sweep.

For many years Mr. Jordan has grown for us the cabbage seed known as "A. S. \& L. Cape Elizabeth" which has proven so satisfactory to our customers.

\section{Allen, Sterling EO Lothrop}

49 Exchange Street and 64 Market Street

Portland, Maine

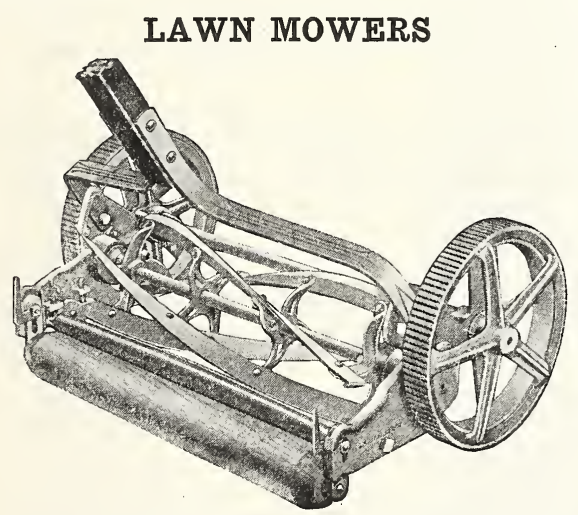

The Timkin Bearing Lawn Mower, 16 in., $\$ 25.00$

The Springfield Ball Bearing Lawn Mower, 16 in., ..................... \$15.00

The Electric Ball Bearing Lawn Mower, 16

in., .....................\$12.00

The Shawnee Lawn Mower, 16 in., .... \$10.00

You are sure to find a mower to meet your requirements at our store.

\section{SERVICE TO GOLF CLUBS}

State Agents for Ideal Power Lawn Mowers Write for Ideal Catalogue

\section{Seed for Putting Green and Fairway}

It has been our privilege to furnish many golf clubs with their special requirements of seed for putting greens and fairways.

We are prepared to quote on special formulas as designated or on the following varieties which are used extensively in the best mixtures.

Red Top, Superfine Recleaned.

Blue Grass, Kentucky.

Bent, German Imported and Colonial.

Fescue, Chewings New Zealand.

We invite correspondence from golf clubs or estates interested in these special varieties.

Write us for quotations on Mixed Fertilizers

Sulphate of Ammonia, Ground Bone and Sheep Manure 


\section{BEANS OF MANY VARIETIES}

\section{Dwarf Green Podded (continued)}

Broad Windsor. (English.) Plant as early in the spring as the ground can be worked, from 2 to 4 inches apart in drills 3 feet apart, cover the seed about 4 inches.

Plkt. 20c., 1 lb. $40 \mathrm{c}, 2$ lbs. $75 \mathrm{c}$.

Red Kidney. Fine for baking and a good shell bean.

1 lb. 20c., 2 lbs. 35 c., 15 lbs. $\$ 2.25$.

Snowflake Pea. The best small white pea bean, early and productive.

1 lb. 20c., 2 lbs. 35c., 15 lbs. \$2.25.

Yellow-Eyed (Old-fashioned). Very productive. Fine for baking, extensively grown as a dry bean for winter use.

1 lb. 20 c., 2 lbs. 35c., 15 lbs. $\$ 2.25$.

Yellow-Eyed (Improved).

1 lb. 20 c., 2 lbs. 35e., 15 lbs. $\$ 2.25$.

\section{Dwarf Wax Podded Beans}

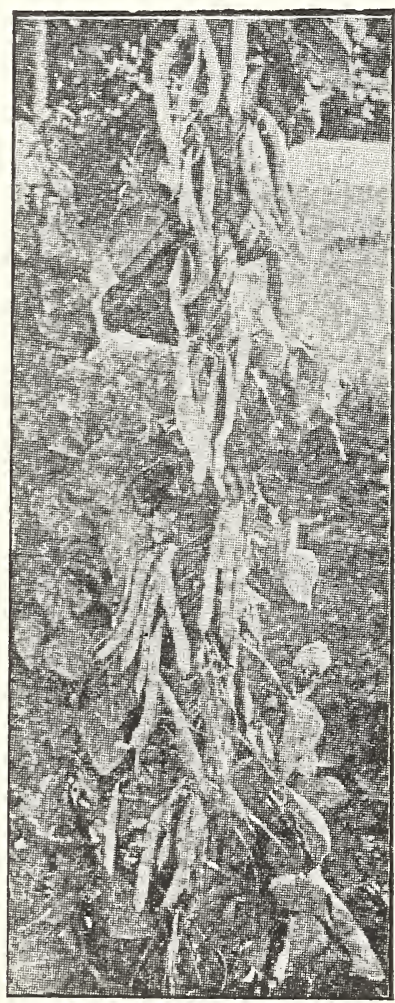

KENTUCKY WONDER

Black Wax, Pencil Pod. Pods are long, pencil like, tender and brittle. In color they are a rich, dark yellow, hardy and productive. Pkt. 15c., 1 lb. 35c., 2 lbs. 60c., 15 lbs. $\$ 3.50$.

Burpee's Kidney Wax. An early and very productive variety, pods are entirely stringless and of fine quality. Free from blight and rust. Pkt. $15 \mathrm{c} ., 1$ lb. 35c., 2 lbs. 60c., 15 lbs. $\$ 3.50$.

Improved Golden Wax. An early, hardy variety, flat, golden-yellow pods. Pkt. 15c., 1 lb. 35c., 2 lbs. 60c., 15 lbs. $\$ 3.50$.

Sure Crop Stringless Wax. A wax-podded variety of remarkable growth and productiveness. Plants hardy and prolific; pods $7 \mathrm{I} / 2$ inches long and about $\mathrm{I} / 2$ inch wide, of a rich vellow color, perfectly stringless, excellent for home and market gardens.

Plit. 15e., 1 lb. 35c., 2 lbs. 60e., 15 lbs. $\$ 3.50$.

\section{Pole Beans} ge.)

If wanted by parcel post add postPlant in hills 4 feet apart, 4 to 5 beans to a hill. Poles should be firmly set before planting.

Horticultural, or Speckled Cranberry. An old favorite, early and prolific; excellent quality either as a snap or shell bean or for cooking dry.

Pkt. 15c., 1 lb. 35c., 2 lbs. 60c., 15 lbs. $\$ 3.50$.

Kentucky Wonder, or Old Homestead. A long, green podded variety, very prolific and of fine quality and perfectly stringless.

Pkt. 15c., 1 lb. 35c., 2 lbs. 60c., 15 lbs. $\$ 3.50$.

Kentucky Wonder Wax. The best pole wax bean; it is similar in habit of growth to "Kentucky Wonder Green Pod.",

Pkt. 15c., 1 lb. 35c., 2 lbs. 60c., 15 lbs. $\$ 3.50$.

Lazy Wife's. Beans white; pods green, very thick, meaty, entirely stringless; very productive.

Pkt. 15c., 1 lb. 35 c., 2 lbs. 60c., 15 lbs. $\$ 3.50$.

Red Cranberry. The poils are green, large and tender; one of the best snap beans.

Plkt. 20c., 1 lb. 40c., 2 lbs. 70c., 15 lbs. $\$ 3.75$.

Yellow Cranberry. Early maturity and very long season. Excellent snap or shell bean. Very prolific, tender and free from strings. Pkt. 20c., 1 lb. 40c., 2 lbs. 70 c., 15 lbs. $\$ 3.75$.

Scarlet Runner. An ornamental climber with bright scarlet flowers. Pkt. 10c., 1 lb. $45 \mathrm{c}$.

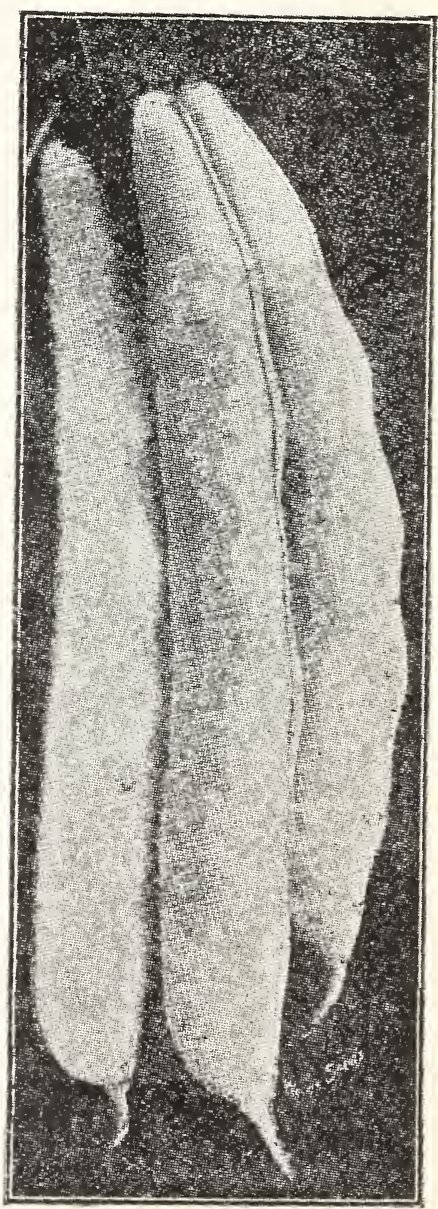

SURE CROP STRINGLESS WAX 


\section{BEET \\ MANGEL WURZEL \\ AND SUGAR BEET}

Sow as early in the spring as the ground can be worked. For succession sow at intervals until the first of July. The soil should be well enriched with stable manure and plowed and harrowed until very fine. Sow in drills 15 inches apart and cover one inch. When well up thin out 4 inches apart in the rows.

One ounce to fifty feet of drill; six pounds to the acre.

EARLY WONDER. A fine early variety, the market gardener's favorite on account of its symmetrical form, dark color, small top and early maturity.

Pkt. 10c., 0z. 20c., 2 oz. 35c., 1/4 lb. 50c., lb. $\$ 1.50$.

Crosby's Egyptian. The roots are flattened, globe shaped and very smooth. Exterior color of root bright red. The flesh is bright vermilion red, zoned with a lighter shade, very sweet, tender and of excellent quality.

Pkt. 10c., oz. 20c., 1/4 lb. 50c., lb. $\$ 1.50$.

Detroit Dark Red. The best beet for the market and home garden. Tops small, upright in growth. Root medium-sized, globular or nearly round, very smooth, and of dark blood red color. Very desirable for bunching. Uniform in growth and unsurpassed in quality.

Pkt. 10c., oz. 20c., 2 oz. 35c., 1/4 lb. 50c., lb. $\$ 1.50$.

Edmand's Blood Turnip. A medium early sort, deep red, popular with market gardeners. Our seed is grown from selected roots saved for seed.

Pkt. 10c., oz. 15c., 2 oz. 25c., 1/4 lb. 35c., lb. 75c.

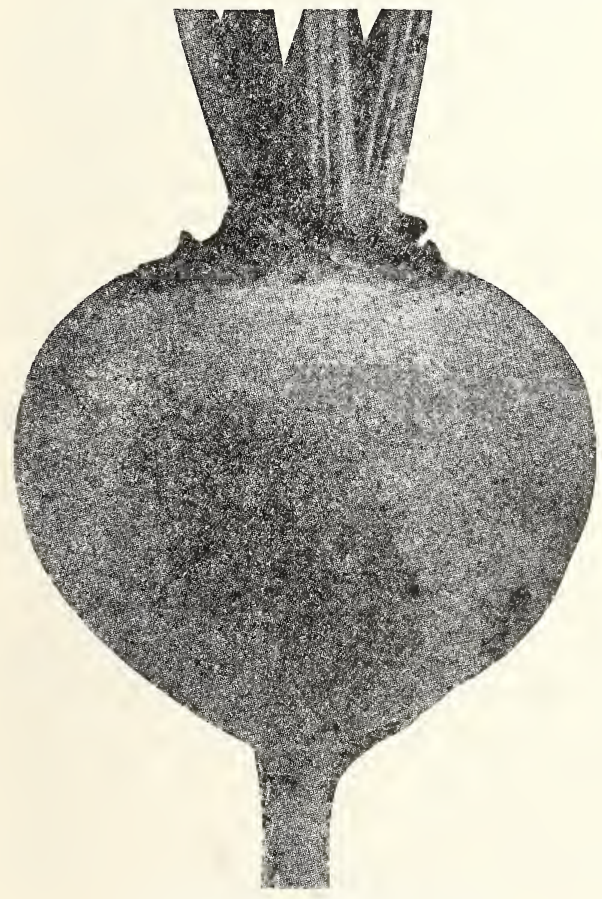

DETROIT DARK RED BEET
Sow in drills 2 inches deep, about 2 feet apart, thin out to 10 inches apart. Six pounds to the acre. Mammoth Long Red. This variety produces roots of mammoth size and is enormously productive. Yielding from thirty to forty tons per acre on well prepared land.

Oz. 10c., 1/4 lb. 25c., lb. 70c., 5 lbs. $\$ 2.50$.

Golden Tankard.

Recommended for dairymen on account of its milkproducing properties. The flesh is a rich golden yellow.

Oz. 10c., $1 / 4$ lb. 25 c., lb. 70c., 5 lbs. $\$ 2.50$.

\section{Giant Sludstrup.}

A large yielding variety of high feeding value.

Oz. 10c., 1/4 1b. 25c., lb. 70c., $5 \mathrm{lbs}$. $\$ 2.50$.

Giant Feeding Sugar Beet or Half Sugar Mangel.

A strain of beets very desirable for stock feeding, affording not only a very large crop much easier to harvest than other sorts, but also having a higher nutritive value, being especially rich in sugar. Roots light bronze green above ground, grayish white below with white flesh.

Oz. 10c., $1 / 4$ lb. 35c., lb. $75 \mathrm{c}$.

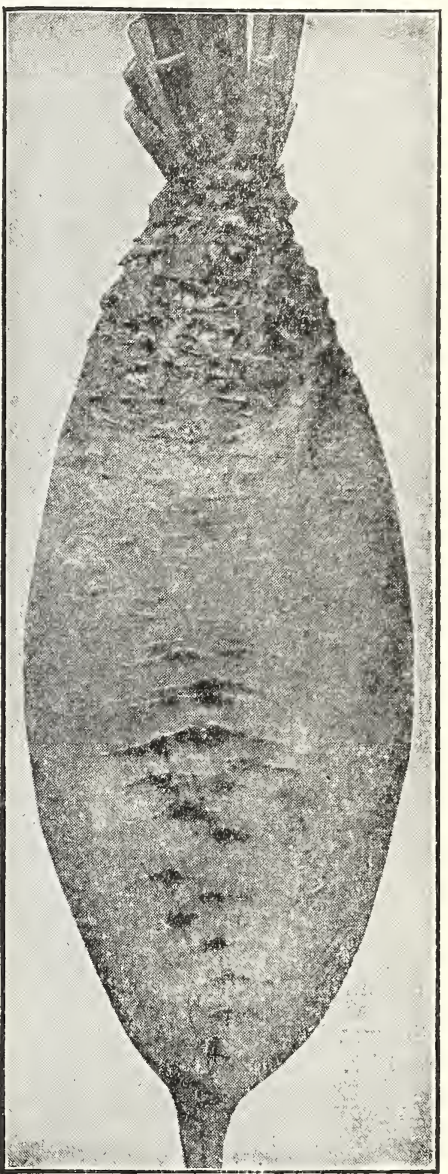

Giant Feeding Sugar Beet, or HALF Sugar MANGEL

\section{Swiss Chard or Spinach Beet}

The leaves are used as greens and served like spinach. The mid-ribs may be cooked like asparagus. Cuttings may be used all summer, as it can be cut down to the ground and new shoots will soon spring up and make fast growth.

Lucullus. The largest and best.

Pkt. 10c., oz. 15c., 1/4 lb. 45c., lb. \$1.25. 


\section{CARROT}

Carrots do best in a good, light and rich soil. Sow in April or May for the early crop, and for the main crop sow in May or June in drills about $1 / 2$ inch deep, in rows 14 inches apart, and thin plants to 3 or 4 inches in the rows.

One ounce to Ioo feet of drill; four pounds to an acre.

Danvers' Half-Long. Special Market Gardeners' Strain. The best sort for the main crop, dark orange color, growing very smooth, yielding large crops, and is a splendid keeper; roots medium length, tapering uniformly to a blunt point. This selected stock we are now offering has been specially grown for market gardeners and is much superior to the ordinary strain of Danvers' Half-Long.

Pkt. 10c., oz. 20c., 1/4 lb. 65c., lb. $\$ 2.00$.

Hutchinson. A carrot of great length and cylindrical shape almost to the point, grows with tops slightly. out of ground, a very heavy yielder per acre. Small circle of green on top of root out of ground portion. Pkt. 10c., oz. 35c., 1/4 lb. $\$ 1.00,1 b . \$ 3.00$.

Chantenay. A medium early, half-long variety. The flesh is crisp and tender.

Pkt. 10c., oz. 20c., 1/4 lb. 60c., lb. $\$ 1.75$.

Improved Long Orange. Deep orange color, roots of large size and good keeper.

Pkt. 10c., oz. 15c., 1/4 lb. 40c., lb. \$1.25.

Guerande or Oxheart. Medium early roots, short and thick. The flesh is bright orange, fine grained and tender.

Pkt. 10c., oz. 20c., 1/4 lb. 50c., lb. \$1.50.

\section{Brussels Sprouts}

Cultivate the same as cabbage. The sprouts resemble miniature cabbage and are very tender.

Improved Dwarf. A standard sort.

Pkt. 10c., oz. 50c., 1/1 lb. $\$ 1.50$.

Improved Long Island. The finest variety, very compact sprouts.

Pkt. 10c., 0z. 50c., 1/4 lb. $\$ 1.50$

\section{Broccoli}

A vegetable much resembling cauliflower.

White Cape. The most desirable variety.

Pkt. 10c., 0z. 60c.

\section{Chervil}

An aromatic sweet herb used for flavoring and garnishing.

Curled. Pkt. 10c., oz. 25c., 1/4 1b. 85c.
Early Scarlet Horn. A favorite early variety, of fine flavor and excellent for the table. Roots grow about three inches long.

Pkt. 10c., 0z. 20c., 1/1/ 1b. 60c., 1b. \$1.75.

Nantes Half-Long Scarlet. A stump-rooted variety. Flesh fine grained, mild and sweet. Pkt. 10c., oz. 20c., 1/4 lb. 50c., lb. \$1.50.

Large White Belgian. Very productive and largely used for feeding stock.

Pkt. 10c., oz. 15c., 1/4 lb. 40c., lb. \$1.25.

\section{Cress or Peppergrass}

Sow early in the spring on rich soil in drills 10 or 12 inches apart and make frequent sowing every two weeks. Cover seed about $1 / 4$ inch.

Extra Curled. Fine flavor, may be cut several times.

Pkt. 10c., oz. 15c., 1/4 1b. 35c.

Water Cress. Sow in the spring near the margin of ponds or running streams.

Pkt. 10c., oz. 60c., 1/4 lb. $\$ 2.00$. 
The cabbage is an important crop and should be planted in fresh, rich soil, well manured and deeply dug or plowed. For early use sow in a hotbed in March, transplant to the open ground when danger from frost is past. Plant the early sorts about 18 inches in the rows and the late sorts about 2 feet in the rows and the rows about 3 feet apart. For the late crops sow in the open ground in June. Our cabbage seed is grown from selected stock and is equal to any offered in the market.

One ounce will produce about 2,000 plants.

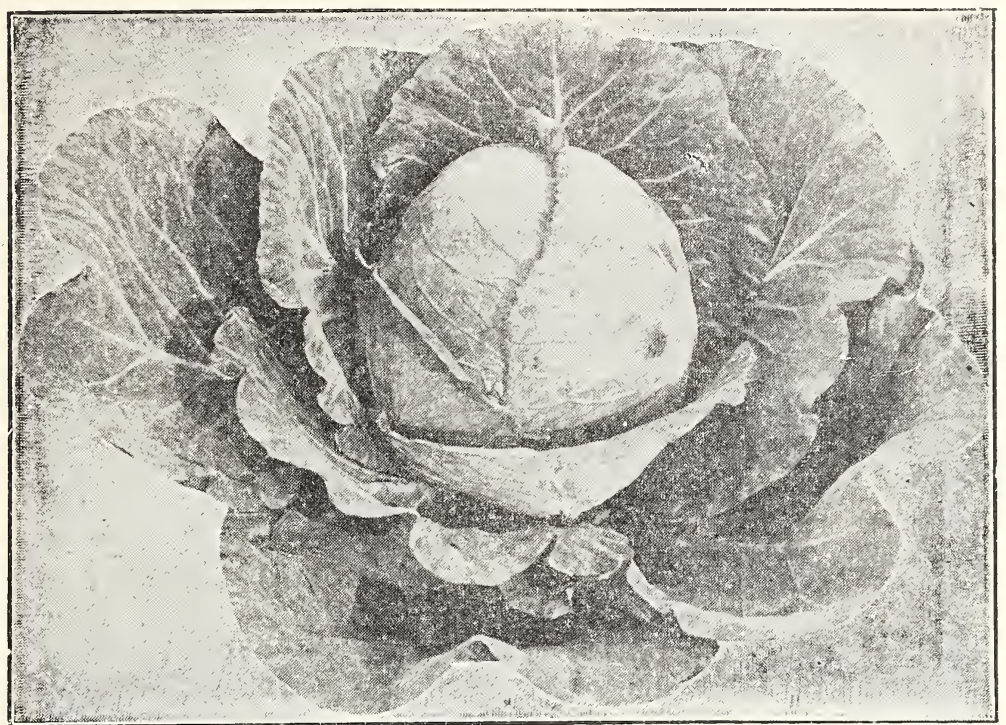

COPENHAGEN MARKET CABBAGE

\section{A. S. \& I. CAPE ELIZABETH.}

Selected seed grown for us at Cape Flizabeth, Maine-a section noted throughout the country for the excellency of its cabbage.

Heads hard, solid, tender and crisp. It is remarkable for its long-keeping qualities. One of the best shipping varieties.

Pkt. 10c., 0z. 75c., 1/4 lb. $\$ 2.50$.

All Seasons. Large heads, round and very solid and sure heading; nearly as early as the Early Summer.

Pkt. 10c., 1/2 oz. 20c., oz. 35c., 1/4 lb. $\$ 1.25$.

Wisconsin Hollander. A late variety, forming globular heads; very hardy and solid. Keeps well and is a good shipper for early spring sales.

Pkt. 10c., 0z. 60c., 1/4 lb. \$1.75, lb. \$6.00.

DANISH BAIL HEAD.

This variety produces large, round and compact heads. One of the best keepers; plants vigorous and hardy, resisting cold and dry weather.

Pkt. 10c., $1 / 2$ 0z. 20c., 0z. 35c., 1/4 1b. $\$ 1.25$.

Danish Ball Head (Tall Stem). This variety is later than the short stem variety. It also is harder and will keep longer; one of the longest reeping White Cabbage varieties.

Pkt. 10 c., oz. 45 c., $1 / 4$ lb. $\$ 1.25,1 b . \$ 4.00$.

Improved American Savoy. Large, solid round heads, of superior quality, tender and good flavor, the best variety for family use.

Pkt. 10c., 1/2 oz. 25c., oz. 40c., 1/4 1b. \$1.50.

Pe-Tsai, or Chinese Cabbage. A quick growing plant resembling Cos Lettuce.

Pkt. 10c., 1/2 0z. 20c., 0z. 35c., 1/4 lb. \$1.00.
COPENHAGEN MARKET. An extra early variety; heads ball-shaped, large and solid, averaging in weight about 10 pounds. The most evenly-maturing and large heading early cabbage.

Pkt. 10c., 1/2 0z. 25c., 0z. 40 c., $1 / 4$ lb. $\$ 1.25$.

Eärly Jersey Wakefield. A standard early market variety, conical in shape and good quality; heads uniform and solid.

Pkt. 10c., 1/2 0z. 20c., oz. $35 \mathrm{c} ., 1 / 4 \mathrm{lb} . \$ 1.00$.

Glory of Enkhuizen. An early white, solid, variety, medium sized heads. Pkt. 10c., 1/2 oz. 20c., oz. $35 \mathrm{c} ., 1 / 4 \mathrm{lb} . \$ 1.00$.

Golden Acre. A First-Early variety of the round-headed type. The head and leaves are a little small. er than that of the Copenhagen Market, and is ready to eut from 8 to 10 days sooner. It is wonderfully true to type. Pkt. 15c., oz. $\$ 1.50,1 / 4 \mathrm{lb}$. $\$ 5.00$.

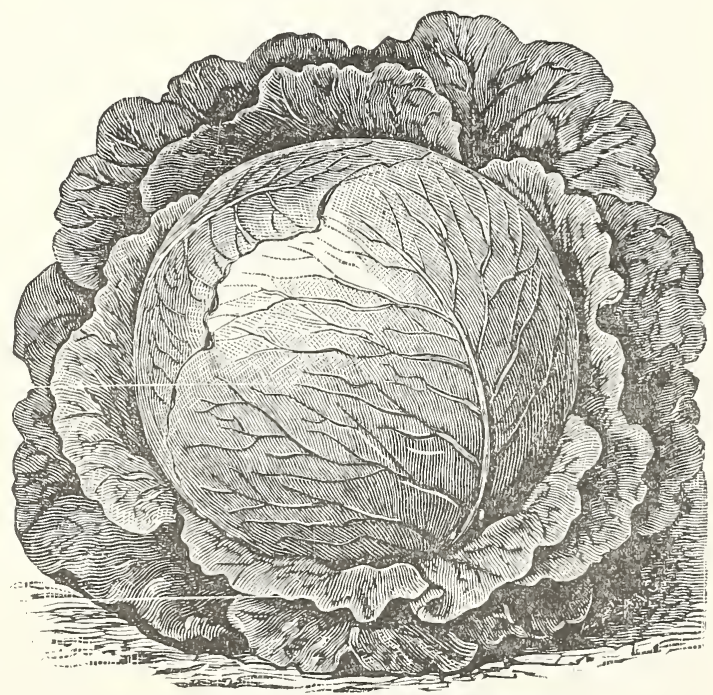

DANISH BALL HEAD OABBAGE

Red Danish Stone Head.

One of the largest and most solid and compact of the red varieties, sure heading and tender. Plkt. 10c., 1/2 0z. 20c., 0z. 35c., 1/4 lb. \$1.25. 


\section{CAULIFLOWER}

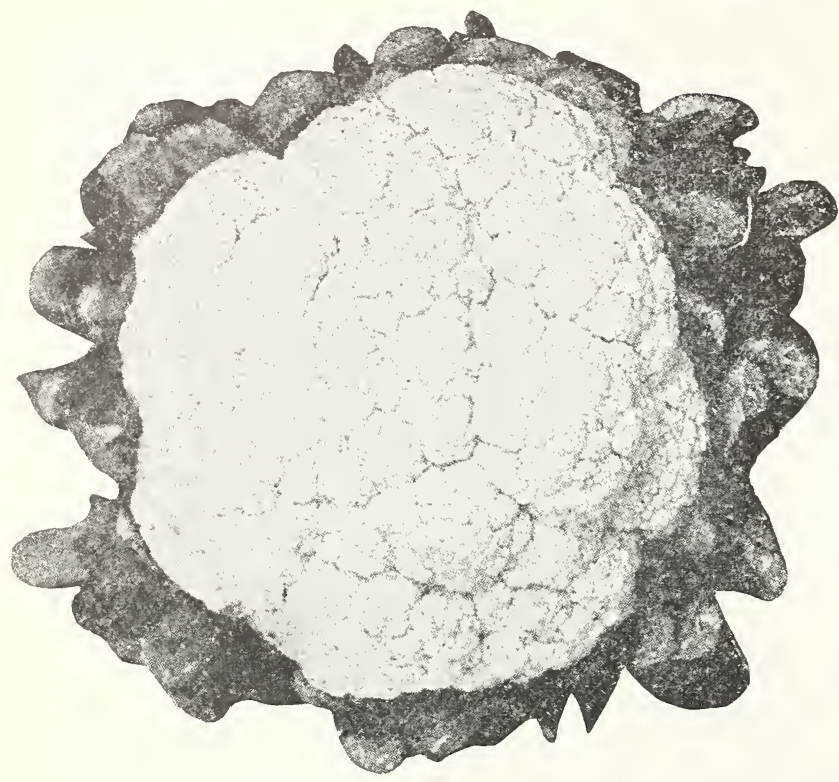

The soil that will grow cabbage will grow cauliflower. It should be made richer and thoroughly worked before planting. For early crop, sow seed in hotbed or in boxes about six weeks before time to plant out. Transplant early in spring in rows 3 feet apart and 18 inches in the row. Plants should be cultivated often to be kept growing continuously. For the late cauliflower, plant in the open ground in June and transplant in July.

One ounce will produce 2,000 plants.

Earliest Dwarf Snowball. The earliest cauliflower in cultivation, absolutely sure to head when conditions are ordinarily favorable. Plants are very dwarf and of compact growth, with large firm, snow-white heads. Plkt. $15 \mathrm{c} ., 1 / 4$ oz. $75 \mathrm{c}$., oz. $\$ 2.50$.

Danish Giant or Dry Weather. This variety is about two weeks later than the Snowball. It is of dwarf growth, producing large hard and snow-white heads, fully protected by its foliage.

Pkt. 15c., 1/4 oz. 75c., oz. \$2.75.

Veitch's Autumn Giant. A large, late sort. Pkt. 10e., $1 / 4$ oz. 30c., oz. $\$ 1.00$.

\section{CELERY}

For early celery sow the seed of the self-blanching sorts in a hotbed early in the spring. As soon as the plants are 3 inches high, transplant into frames in well-enriched soil 4 inches apart. Cut them once or twice before setting them out in May or June to make them stocky. When about six inches high transplant into trenches wide enough to hold two rows. The rows should be about 1 foot apart and the plants set about 8 inches apart. For winter celery start the seeds in flats as for early, only a little later. As plants grow they should be earthed up to blanch, taking care not to cover the center of the plant.

One ounce of seed will produce about 4,000 plants.

Wonderful. This new variety of Celery, rightly named Wonderful, is of the Paris Golden family, but twice to three times its size, very fine quality, and very free from the stringy habit of the Old Golden.

Pkt. 15 c., oz. $\$ 1.50,1 / 4$ lb. $\$ 5.00$.

Easy-Blanching. A first early variety, the stalks are very tender and brittle, and have a rich nutty flavor.

Pkt. $10 \mathrm{c} ., 1 / 2$ oz. $50 \mathrm{c}$., oz. $85 \mathrm{e} ., 1 / 4$ lb. $\$ 3.00$.

Paris Golden Self-Blanching. (French grown, speeial gardeners' strain.) The finest early celery grown, easily blanched and of excellent flavor, solid and crisp.

Pkt. 10e., 1/2 oz. 50c., 1 oz. 85e., 1/4 lb. $\$ 3.00$.

White Plume. A desirable early variety requiring very little labor in blanehing.

Pkt. 10c., 1/2 oz. 30c., oz. 50c., 1/4 lb. $\$ 1.75$.

Boston Market. White, solid, erisp and tender, the best late

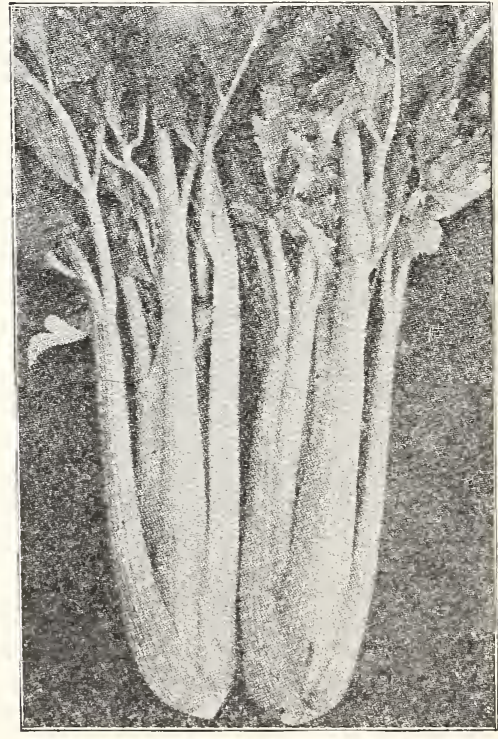

GOLDEN SELF-BLANCHING variety.

Pkt. 10c., 1/2 oz. $40 \mathrm{c}$, oz. 75c., 1/4 lb. $\$ 2.00$.

Celeriac or Turnip-Rooted Celery. It is mostly grown for the edible root and not for greens. Sow seed same as Celery, transplant into rows two feet apart and about six to eight inches in the row.

Large Smooth Prague. An improved form of turnip-rooted celery, producing large, smooth roots, which are almost round and of fine flavor.

Pkt. 10c., 0z. 25e., $1 / 4$ 1b. $75 \mathrm{c}$.

Soup Celery. For flavoring.

Oz. 10e., 1/4 1b. 20e., lb. 60e. 


\section{SWEET CORN}

Plant in hills 3 to 4 feet apart each way, dropping 6 seeds in each hill, or in drills 3 to 4 feet apart.

The seeds should be covered about 2 inches. In this climate Sweet Corn should not be planted before the middle of May.

One pound will plant 100 hills.

If wanted by Parcel Post, add postage-See table page 2.

Early Falmouth (New). An extra early variety with good sized ears. The stalks are short with little foilage, 4 to 5 feet high; the sweetest and most tender of the early varieties. Gardeners trying for the earliest market should include it in their order.

Pkt. 20c., 1 lb. 40c., 2 lbs. 70c., 10 lbs. $\$ 2.50$.

Burpee's Golden Bantam. Early, hardy and of the most delicious flavor; being of a dwarf growth, the stalks can be grown closely together in the row.

Pkt. 15c., 1 lb. 35c., 2 lbs. 65c., 10 lbs. $\$ 2.50$.

Charlevoix. An intermediate, yellow grained sweet corn of distinctive merit. Ears about seven inches long, usually twelve rowed and when in condition for use are light creamy yellow in color. The grain is rather short, very sweet and tender. An excellent sort both for the home and the market garden.

Pkt. 15c., 1 lb. 35c., 2 lbs. 60c., 10 lbs. $\$ 2.25$.

DeLue's Golden Giant. Nearly as early as Golden Bantam and of fine quality. Much larger ears, being from 12 to 16 rows of golden yellow.

Pkt. 15c., 1 lb. 35c., 2 lbs. 65c., 10 lbs. $\$ 2.50$.

Bantam Evergreen. A cross between Stowell's Evergreen and Golden Bantam. Kernels are plump and full. The quality is very fine, being exceedingly sweet and tender. Ears 5 to 7 inches long.

Pkt. 15c., 1 lb. 35c., 2 lbs. 60c., 10 lbs. $\$ 2.50$.

Early Crosby (Selected). An early and productive variety; growing very dwarf with ears set low, averaging from 16 to 20 rows; very sweet and tender. Desirable for both the market and private garden.

Pkt. 15c., 1 lb. 35c., 2 lbs. 60c., 10 lbs. $\$ 2.50$.

Stowell's Evergreen. A late standard sort of excellent quality. Pkt. 15c., 1 lb. 35c., 2 lbs. 60c., 10 lbs. $\$ 2.50$.

The Eclipse Rotary Corn Planter

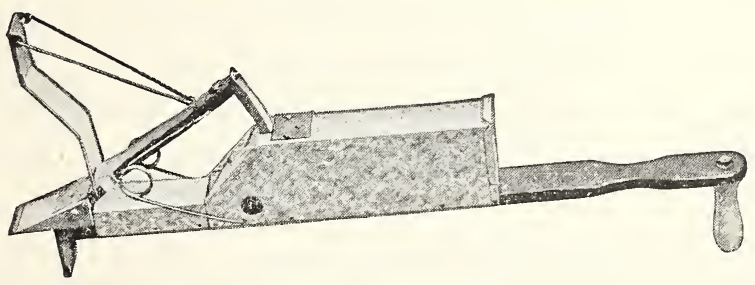

Eclipses all others; has positive feed.

Four changes of dises. Eclipse is the easiest operating planter on the market.

Price, $\$ 2.50$

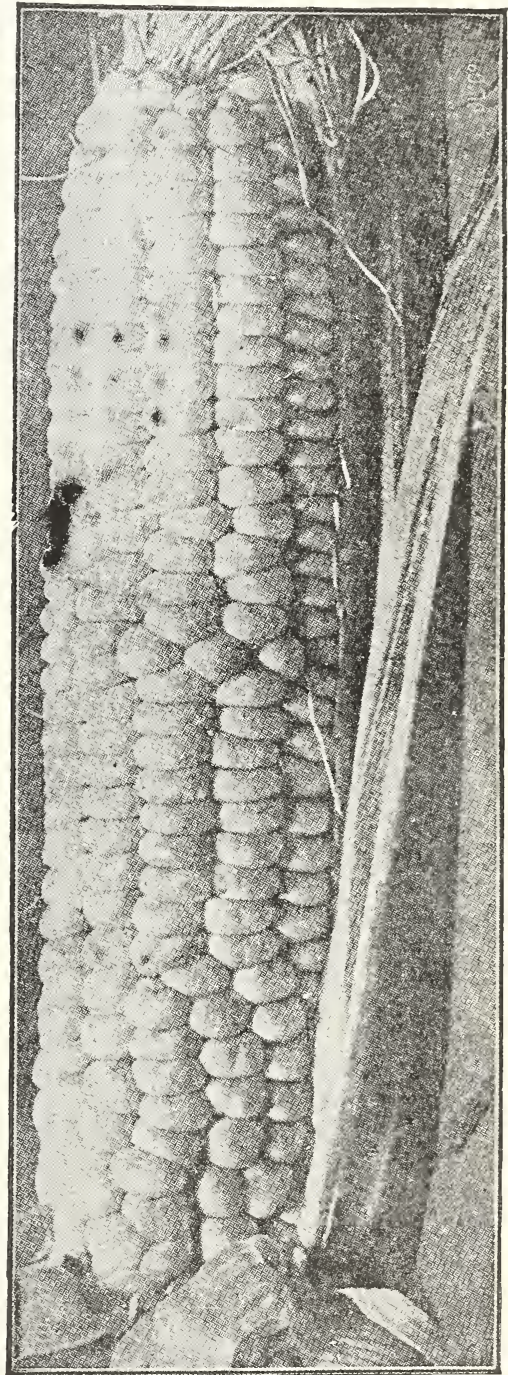

BURPEE'S GULDEN BANTAM CORN 


\section{(1)}

\section{CUCUMBER}

For general crop plant when the ground has become warm, in hills 4 feet apart each way. Thin out to 4 plants to each hill after all danger of insects is over. For very early cucumbers sow about April 1st, in a hotbed on a piece of sod, grass side down so that they can be easily transplanted to the open ground when danger of frost is orer.

One ounce will plant fifty hills; two pounds will plant an acre.

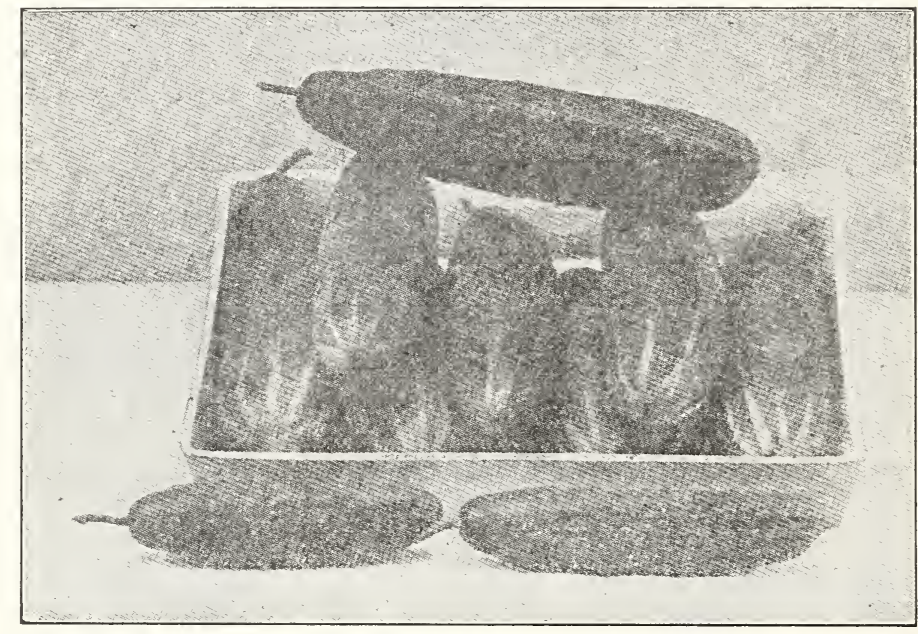

WOODS HYBRID CUCUMBER

WOODS HYBRID. The best type of slicing cucumber. The color, a rich dark green, is retained a long time after it is picked. The flesh is white, crisp and tender. It is early and prolific, and for home or market, it is far superior to other sorts.

Pkt. 10c., oz. 20c., 1/4 lb. 60c., lb. $\$ 2.00$.

Boston Pickling. This variety is largely planted for pickles. Fruit medium size, smooth, light green and very productive.

Pkt. 10c., oz. 20c., 1/4 lb. 60c., lb. $\$ 1.50$.

Cumberland. Fine variety for pickling or slicing. Vines are strong growth and prolific and continue in bearing a long time.

Pkt. 10c., oz. 20c., 1/4 lb. 60c., lb. \$1.50.

Davis Perfect. For foreing or outdoors. The fruit is of fine form, of a rich dark green color, very few seeds, tender, brittle and of fine flavor. Pkt. 10c., oz. 20c., 1/4 1b. 60c., 1b. \$2.00.

Early Cluster. An early sort growing in clusters. Pkt. 10c., oz. 20c., 1/4 lb. 60c., lb. $\$ 1.50$.

Early Frame or Short Green. A well-known variety used for slicing and pickling.

Pkt. 10c., oz. 20c., 1/4 lb. 60c., 1b. $\$ 1.50$.
Improved White Spine. One of the most popular varieties in cultivation. The fruit is light green with white spines, uniform in size and very productive.

Pkt. 10e., oz. 20c., 1/4 lb. 60c., lb. $\$ 1.50$.

Early Russian. One of the earliest varities, grows from 3 to 4 inches long.

Plit. 10c., oz. 20c., 1/4 lb. 60c., 1b. $\$ 1.50$.

Japanese Climbing. A quick-growing sort, throwing out tendrils which enable them to climb poles or trellises. Fruit from 12 to 16 inches long.

Pkt. 10c., oz. 20c., 1/4 lb. 60e., lb. $\$ 1.50$.

Klondike. A medium early cucumber of very dark green color and an excellent quality for slicing; vine very hardy and productive. The fruits, when mature, are about $S$ inches long. Its uniform size and shape and splendid color make this variety very popular as a shipping sort. Plit. 10c., oz. 20c., 1/1 lb. 60c., lb. $\$ 1.50$.

Long Green. An old standard variety. Fruit from 10 to 12 inches long, dark green and crisp.

Pkt. 10c., oz. 20c., 1/4 lb. 60c., 1b. $\$ 1.50$.

West India Gherkin. A small prickly variety grown only for pickles.

Pkt. 10c., oz. 20c., 1/4 lb. 60c. 


\section{DANDELION}

One of the earliest and most popular of spring greens. Sow in May in drills 12 inches apart; cover the seed $1 / 4$ of an inch deep. The following spring the plants will be ready for cutting.

One ounce for 200 feet of drill.

Improved Thick-Leaved. A carefully selected strain; popular with market gardeners.

Pkt. 10c., 0z. 90c., 1/4 lb. $\$ 3.00$.

\section{EGG PLANT}

Sow the seeds in lotbeds very early in the spring and transplant when about three inches high into small pots or another hotbed. Do not plant out in the open ground until the weather has become warm and settled.

One ounce will produce about I,000 plants.

New York Improved Purple. This variety produces fruit of large size, nearly round, dark purple and excellent quality.

Pkt. 10c., 1/2 oz. 35c., oz. 65e.

Black Beauty. A valuable early sort, about ten days earlier than the New York Improved; color a rich purplish black.

Pkt. 10c., 1/2 0z. 35c., oz. 65c.

\section{ENDIVE}

For early use sow as early in the spring as the ground can be worked in drills 15 inches apart. Tramsplant to 1 foot each way. When full grown tie the outer leaves at the top to blanch them.

One ounce will produce 2,000 plants.

Green Curled. A standard sort for fall and winter.

Pkt. 10c., oz. 15c., 1/4 1b. 50c., lb. \$1.25.

White curled. A fine, white curled variety, selfblanching.

Pkt. 10c., oz. 15c., 1/4 lb. 50c., 1b. \$1.25.

Broad-Leaved Batavian. A variety growing very compact, very tender and of fine flavor.

Pkt. 10c., 0z. 15c., 1/1 lb. 50c., lb. $\$ 1.25$.

French Endive (Witloof Chicory). Plant the seed in drills 10 inches apart, in deep, rich soil. Thin to six inches apart. One of the finest winter salads grown.

Pkt. 10c., oz. 30c., 1/4 lb. $\$ 1.00$.

\section{KALE}

Sow from May to June, broadeast or in drills, cover 1/2 inch, cultivate the same as cabbage.

One ounce to I 50 feet of drill.

Dwarf Green Curled Scotch. A fine, low-growing variety, the leaves densely crimped and curled; very hardy and productive.

Pkt. 10c., oz. 15c., 1/4 lb. 50c.

\section{KOHL RABI}

Seeds should be sown in drills as early in the spring as possible. When well established thin to 6 inches apart. The bulb grows entirely out of the ground.

Early White Vienna. A very early sort, excellent quality flesh white and tender.

Pkt. 10c., oz. 25c., 1/4 lb. $75 \mathrm{c}$.

Early Purple Vienna. Similar to the above except in color.

Pkt. 10c., 0z. 25c., 1/4 lb. 75c.

\section{MUSK MELON}

Melons succeed best in light, sandy rich soil. After all danger of frost is past plant in hills 4 to 6 feet apart each way, six to ten seeds to a hill. When about 3 inclies high and all danger from insects is past thin out to 3 or 4 plants to a hill.

One ounce to 60 hills; two or three pounds to an acre.

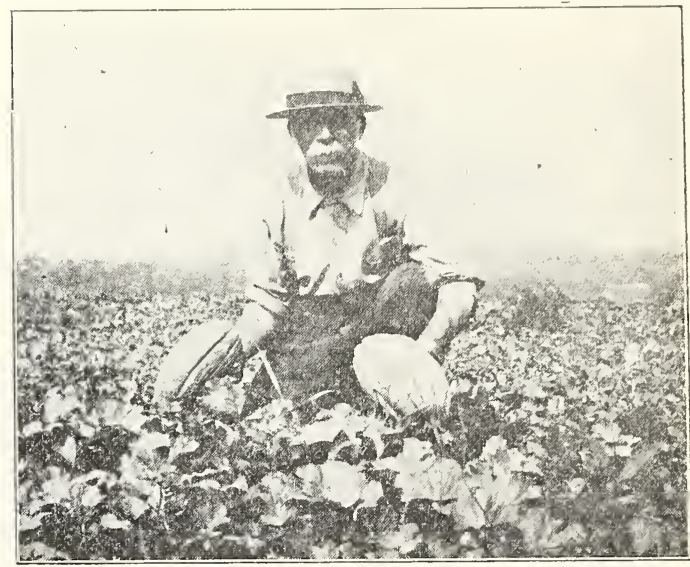

A. S. \& L. MUSK MELONS GROWING IN MAINE

“A. S. \& L.', A very large variety, thickly netted, deeply ribbed, flesh salmon-yellow, thick and sweet. A great yielder. It ripens from 70 to 80 days from time of planting.

Pkt. 10c., oz. 50e., 1/4 lb. $\$ 1.50$.

Fmerald Gem. Fruit of medium size, very early and of fine flaror; flesh deep orange. Pkt. 10c., oz. 15c., 1/4 1b. 50c.

I ong Yellow. Very large, slightly ribbed and thickly netted; flesh salmon-yellow and sweet. Pkt. 10c., oz. 15c., 1/4 1b. 50e.

Rocky Ford. A popular market variety. The fruit is oval, medium size, finely netted; flesh light green and very sweet. Pkt. 10c., 0z. $15 \mathrm{c} ., 1 / 4$ lb. $50 \mathrm{c}$.

Honcy Dew. A medium sized melon 5 to 6 pounds in weiglit, about 6 inches diameter and slightly oblong. Thick flesh, light emerald green in color.

Pkt. 10c., oz. 15c., 1/4 lb. 50c.

\section{WATER MELON}

Plant in hills about 8 feet apart and cultivate the same as for Musk Melon.

One ounce for 30 hills; four pounds for one acre.

Cole's Early. One of the best early varieties, medium size, nearly round, flesh dark red and excellent quality.

Pkt. 10c., 0z. 15c., 1/4 1b. 50c.

Phinney's Early. Early and productive, flesh red. Pkt. 10c., 0z. 15c., 1/4 1b. 35c.

Citron. Used for preserves; white flesh, hardy and productive.

Pkt. 10c., 0z. 15c., 1/4 lb. 35c. 
Salamander. Medium size, light green, and forms a hard buttery head of fine quality.

\section{LETTUCE}

For summer use the seed can be sown in hotbeds in March. Transplant when the weather will permit in rows 12 inches apart and 8 inches apart in the rows. For a succession sow in the open ground every two weeks until fall. Lettuce requires a rich and a rather moist soil. The more rapid the growth, the better the quality.

Once ounce of seed will produce about 3,000 plants.

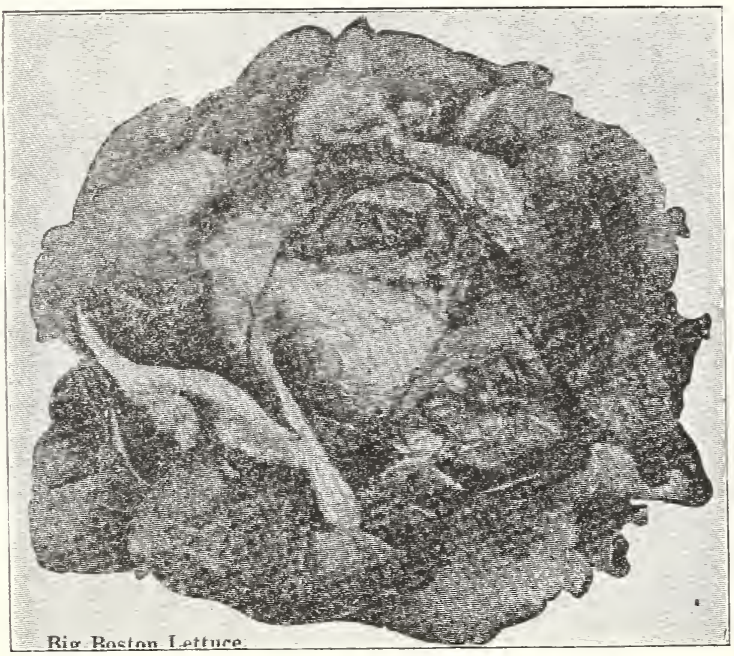

Big Boston. Fine for forcing or open-ground planting; large, solid heads.

Pkt. 10c., oz. 20c., 1/4 lb. 60c.

Boston Curled. Leaves beautifully curled, very attractive on table.

Pkt. 10c., 0z. 20c., 1/4 lb. 60c.

Crisp as Ice. Large, solid heads, yellow heart, outside dark green and bronze.

Pkt. 10c., 0z. 20c., 1/4 lb. 60c.

Grand Rapids. A very popular variety, leaves crimpled, vary attractive, matures quickly; the heads are dark green, very crisp and tender. Pkt. 10c., 0z. 20c., 1/4 1b. 60c.

Hanson. A large, solid variety. Pkt. 10c., 0z. 20c., 1/4 1b. 60c.

Iceberg. A very superior solid heading variety for out-door growing. Makes large, solid heads. Pkt. 10c., oz. 20c., 1/4 lb. 60c.

Market Gardener's Private Stock. A strain of Black-Seeded Tennis Ball, very desirable for hotbed culture in winter and for withstanding heat in summer. A light green cabbage sort, forming hard heads.

Pkt. 10e., oz. 25e., 1/1 lb. 70e.

May King. Large, round, solid heads, one of the best varieties for planting in open ground. Pkt. 10c., 0z. 20c., 1/4 1b. 60c.

INew York or Wonderful. The largest head lettuce, crisp and tender.

Plit. 10c., 0z. 20c., 1/t 1b. 60e.
Pkt. 10c., oz. 20c., 1/4 lb. 60c.

Tennis Ball, Black Seeded. A favorite variety for out-door crop; forms close, hard heads that are crisp and tender.

Pkt. 10c., oz. 20c., 1/4 lb. 60c.

\section{Romaine or Cos Varieties}

Paris White Cos. An early sort with long, narrow leaves.

Plkt. 10c., 0z. 20c., 1/4 lb. 60c.

Trianon, Self-Folding Cos. Requires no tying to blanch; very crisp.and tender.

Pkt. 10c., 0z. 20c., 1/1 lb. 60c.

\section{LEEK}

Plant in the spring in a light, well-enriched soil in drills 1 foot apart. Cover the seed about 1 inch and thin to 9 inches apart in the drills. Draw earth up to them as they grow.

One ounce of seed to I 50 feet of drill.

American Broad Flag. A strong-growing sort with broad leaves.

Pkt. 10c., oz. 25c., 1/4 lb. 75c.

\section{MARTYNIA}

The seed pods which are produced in great abundance are gathered when young and tender for pickling. Sow in the open ground in May, 3 feet apart each way.

Proboscidea. The most productive variety.

Pkt. 10c., 1/2 0z. 25c., 0z. 40 c., 1/4 lb. $\$ 1.25$.

\section{MUSHROOM SPAWN}

Mushrooms can be grown in cellars, in sheds, or in hotbeds where a temperature of 50 to 70 degrees is easily maintained.

English Spawn. In bricks 25c. per lb., 6 lbs. for $\$ 1.25$. If wanted by mail, add 10 cents per $1 b$.

\section{MUSTARD}

Sow thickly in early spring in shallow drills or in boxes during the winter. Successive sowing may be made every ten days.

One ounce will sow about 75 feet of drill.

Chinese. Leaves twice the size of the ordinary White Mustard, which are curled and eaten boiled like spinach.

Plit. 10c., oz. 15c., 1/1 1b. $25 \mathrm{c} ., 1$ lb. $75 \mathrm{c}$.

White London. The best for salads and flavoring. Plit. 10c., oz. 15c., 1b. 50c. 


\section{ONION}

Sow the seeds as early in the spring as the ground can be worked in drills about 1 foot apart and cover about $1 / 2$ inch. Thin plants to stand from 2 to 3 inches apart in the drills. The soil should be made very rich and kept free from weeds.

One ounce to Ioo feet of drill; five pounds to the acre.

Danvers Yellow Globe. The most profitable variety to grow, producing bulbs of globular form which ripen early and uniformly, producing large crops. The seed we offer was grown in New England from selected bulbs by a reliable grower of long experience. We cannot recommend this strain of seed too highly, not only on account of its great yield but also of its superior keeping qualities.

Pkt. 10c., 0z. 30c., 1/4 lb. 90c.

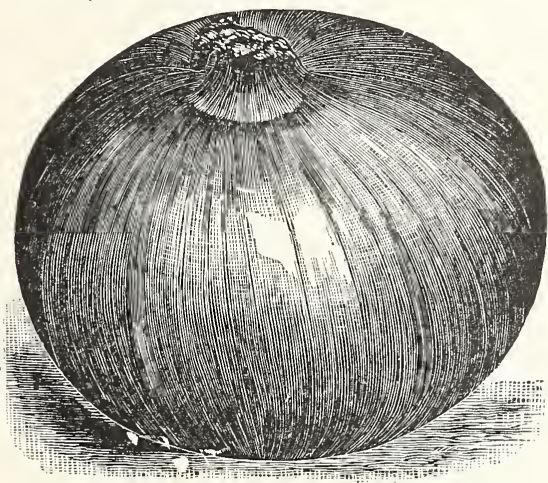

DANVERS YELLOW GLOBE ONION

Extra Farly Red Flat. About ten days earlier than the Red Wethersfield, medium size and a good keeper.

Pkt. 10c., oz. 30c., 1/4 lb. 90c。

Large Red Wethersfield. The standard red, flat variety, large size, skin deep purplish red, a good keeper.

Pkt. 10c., 0z. 30c., 1/4 lb. 90c.

Prizetaker. The largest yellow onion, flesh white and of mild flavor.

Pkt. 10c., oz. 30c., 1/4 lb. 90c.

White Portugal. One of the best white sorts; bulbs mature early, very mild flavor, the best to grow for sets.

Pkt. 10c., oz. 30c., 1/4 lb. 90c.

\section{ONION SETS}

(Recleaned). Onion Sets should be planted as early in the spring as the ground is dry enough to work, in rows 12 inches apart and 2 to 4 inches apart in the rows.

If sent by mail add postage. See table, front cover.

White Onion Sets. Qt. (1 lb.) 35c., pk. (8 lbs.) $\$ 2.00$.

Japanese Onion Sets. This onion will actually double the yield of any other onion set on the market. If the sets are planted early in the spring the onions will be ripe in July and can be used all through the fall and winter. It throws few seed stalks, is an excellent keeper and the flavor is mild and sweet. Qt. (1 lb.) 35c., pk. (8 lbs.) $\$ 2.00$.

\section{PARSLEY}

Soak the seeds a few hours in lukewarm water and sow early in the spring in rich soil in drills one foot apart, thin out the plants to 4 inches apart in the rows.

One ounce to I 50 feet of drill.

Double Curled or Covent Garden. One of the best sorts, handsome bright green color; leaves finely crimped and curly.

Pkt. 10c., oz. 15c., 1/4 lb. 45c.

Fern Leaved. A fine strain, very dark green. Pkt. 10c., 0z. 15c., 1/4 lb. $45 \mathrm{c}$.

Hamburg or Turnip-Rooted. The roots resemble a small parsnip; used for flavoring soups, etc. Pkt. 10c., 0z. 15c., 1/4 lb. 45 c.

\section{PARSNIP}

Sow as early in the spring as the weather will permit in deep, rich soil in drills 18 inches apart, covering the seed slightly; thin to 5 or 6 inches apart in the rows.

One ounce to Ioo feet of drill; five pounds to the acre.

Abbott's Improved Hollow Crown. The roots are smooth. tender and sugary; a heavy cropper.

Pkt. 10c., 0z. 20c., 1/4 lb. 60c., 1b. \$1.50.

Arlington Long Smooth. Roots long and smooth; a good market sort.

Pkt. 10c., oz. 20c., 1/4 lb. 60c., lb. \$1.50.

\section{PEPPER}

Sow the seed in hotbeds early in April. Transplant when 2 or 3 inches high to 3 inches apart. Transplant to the open ground about the first of June, in rows 2 feet apart and 18 inches apart in the rows. The soil should be rich and mellow.

One ounce will produce about 2,000 plants.

Iarge Bell or Bull Nose. Large and of mild flavor, largely used for pickling.

Pkt. 10c., 1/2. oz. 35c., oz. 60c.

Iong Red Cayenne. Bright red, long, slender pods, very pungent.

Pkt. 10c., $1 / 2$ oz. 40 c., oz. 75c.

Pimento. A very thick fleshed sweet variety, uniform in shape and size. Color dark green changing to a brilliant red. Very desirable for salads on account of its fine flavor ând superior quality.

Pkt. 10c., 1/2 oz. 25c., 1/4 1b. \$1.25.

Squash or Tomato-Shaped. Fruit medium size, early and productive.

Pkt. 10c., 1/2 0z. 35c., 0z. 65c.

Sweet Mountain. The fruit is very large and smooth, flesh very tender and mild flavored. Pkt. 10c., 1/2 oz. 35c., 0z. 65c.

Sweet Italian. A superb variety of exceedingly mild flavor. Grows 6 to 7 inches in length and 2 to 3 inches thick at the base. Very attractive in appearance. The fruit is light green, turning bright scarlet.

Pkt. 10c., 1/2 oz. 30c., oz. 50c. 


\section{GARDEN PEAS}

Sow the early, smooth, round sorts as early in th s spring as the ground can be worked, in light, dry rich, loamy soil. The wrinkled varieties are more tender and the seed is more liable to rot and should not be planted when the ground is cold and wet. The late varieties do not require as rich soil as the early and dwarf sizes. Sow in rows 3 to 4 feet apart and about 1 inch apart in the rows, 3 to 4 inches deep. Peas grown as a market crop are never staked, but when the taller sorts are grown for private use they are generally sown in double rows, 6 to 8 inches apart, and staked with brush. For best results all garden peas require good, strong, fertile soil.

One pound will plant about 50 feet of drill.

Those marked with a $\left(^{*}\right)$ are wrinkled varieties.

If wanted by Parcel Post, add postage-see table, page 2.

\section{Extra Early Varieties}

Alaska. One of the earliest blue peas, pods dark green, of medium size and uniform in growth; height $2 \frac{1}{2}$ feet.

Pkt. 15c., 1 lb. 30c., 2 lbs. 50c., 7 lbs. $\$ 1.50,14$ lbs. $\$ 2.75$.

*Gradus or Prosperity. The earliest and most popular of the large-podded, wrinkled peas; vines vigorous, bearing large pods from 4 to $4 \frac{1}{2}$ inches in length, filled with large peas of the finest quality and delicious flavor; height 3 feet.

Pkt. 20c., 1 lb. 35e., 2 lb. 60e., 7 lbs. $\$ 1.75,14$ lbs. $\$ 3.25$.

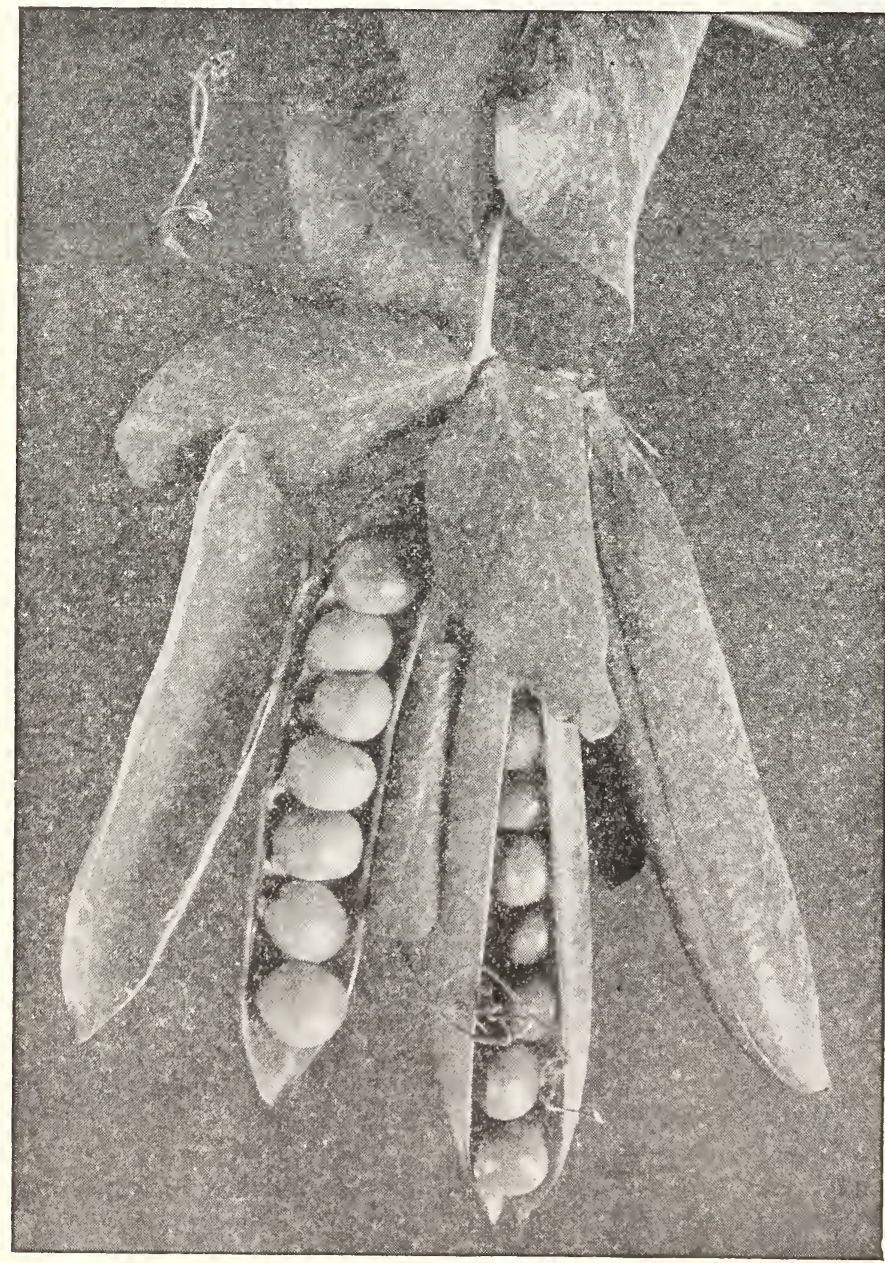

GRADUS PEAS
*Laxtonian. One of the most remarkable varieties yet introduced; very dwarf, growing only 12 to 15 inches high, producing pods in great abundance; nearly as large as the Telephone. The peas are large with a flavor the very sweetest and best. Pkt. 20e., 1 lb. 35e., 2 lbs. 60c., 7 lbs. $\$ 2.00,14$ lbs. $\$ 4.00$.

*Early Morn. Of Gradus type, the pods are large and well filled with peas of excellent flavor; height 3 feet.

Pkt. 20c., 1 lb. 35c., 2 lbs. 60e., 7 lbs. $\$ 1.75,14$ lbs. $\$ 3.25$.

*Little Marvel. A dwarf variety of even growth, about 18 inches in height; pods dark green, medium size, often produced in pairs; as early as Nott's Excelsior, equal in flavor and more prolific.

Pkt. $20 \mathrm{e}, 21$ lb. 35e., 2 lbs. 60e., 7 lbs. $\$ 1.75,14$ lbs. $\$ 3.25$.

*Nott's Excelsior. A splendid early sort; pods are always well filled with large peas of delicious flavor. Height 15 inches.

Pkt. 20c., 1 lb. 35e., 2 lbs. 60e., 7 lbs. \$1.75, 14 lbs. \$3.25.

*Sutton's Excelsior. As early as Nott's Excelsior, with much larger pods, a large cropper and of rich flavor; height 11 , feet.

Pkt. 20e., 1 lb. 35e., 2 lbs. 60e., 7 lbs. \$1.75, 14 lbs. \$3.25.

*Sutton's World's Record. Habit very prolific; pods long, dark green, filled with peas of superb flavor; height 3 feet.

Pkt. 20e., 1 lb. 35e., 2 lbs. 60e., 7 lbs. $\$ 1.75,14$ lbs. $\$ 3.25$.

*Thomas Laxton. Similar to Gradus. The pods are long, straight, with square ends, and contain 7 or 8 peas of the finest flavor; hardy and productive; height 3 feet.

Pkt. 20c., 1 lb. 35c., 2 lbs. 60e., 7 lbs. $\$ 1.75,14$ lbs. $\$ 3.25$.

*Burpee's ' Blue Bantam.', An extra early variety of the finest quality. The vines average fifteen inches in height. The pods average nearly as large as the Gradus. Pkt. 20e., 1 lb. 35e., 2 lbs. 60e., 7 lbs. $\$ 1.75,14$ lbs. $\$ 3.25$. 


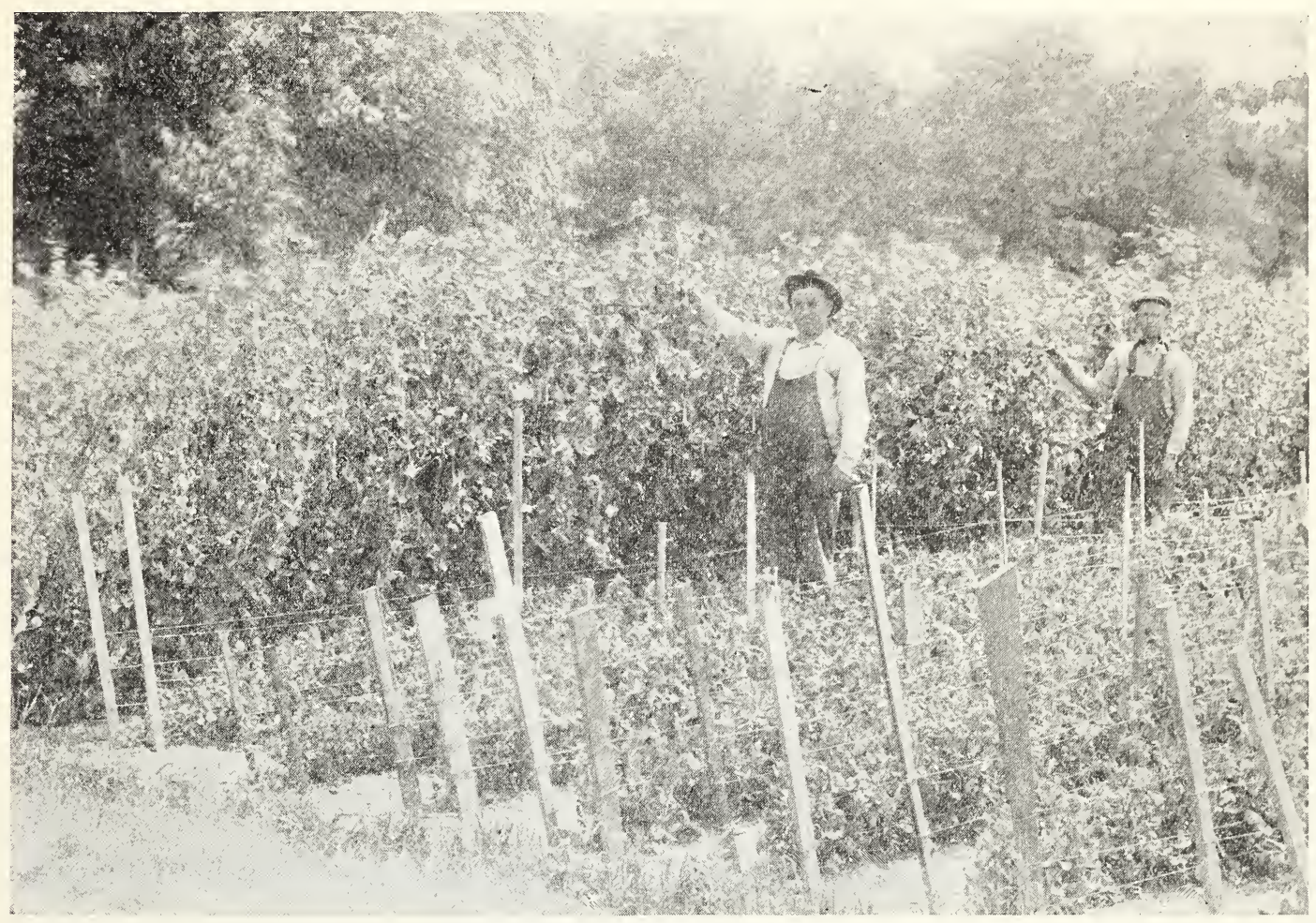

\begin{abstract}
Allen, Sterling \& Lothrop, Portland, Maine.
Dear Sirs: - This picture shows the result of planting A. S. \& L telephone peas and will say: After using your seeds for the past five years, on the Wm. Penn Whitehouse estate, Cumberland Foreside, I think them excelled by none. They have given me perfect satisfaction.

Ralph R. Anderson.
\end{abstract}

\section{MEDIUIM AND LATE VARIETIES}

*Dwarf Telephone (Carter's Daisy). Similar to the Tall Telephone, bearing heavy pods, about $41 \frac{2}{2}$ inches long, height 2 feet.

Pkt. 20c., 1 lb. 35c., 2 lbs. 60c., 7 lbs. \$1.75, 14 lbs. $\$ 3.25$.

*Everbearing. Very prolific, pods about 3 inches long, peas. large and of good quality; height $21 \%$ feet.

Pkt. 20c., 1 lb. 35c., 2 lbs. 60c., 7 lbs. $\$ 1.75,14$ lbs. $\$ 3.25$.

*Carter's Quite Content. The largest-podded variety yet introduced, vines and pods deep green, pods 7 to $71 / 2$ inches long, hanging mostly in pairs and contain 9 to 11 large peas of excellent flavor; recommended for the market or private garden; a large cropper; height of 3 to 4 feet. Pkt. 25c., 1 lb. 45c., 2 lbs. 80 c., 7 lbs. $\$ 2.60,14$ lbs. $\$ 5.00$.
*Admiral Dewey. One of the finest and most desirable of the large-podded varieties. The vines are of vigorous growth; the pods are always of good size well filled with peas of the highest quality; specially recommended for the home garden and market growing; height 4 feet.

Pkt. 20c., 1 lb. 35c., 2 lbs. 60c., 7 lbs. \$1.75, 14 lbs. $\$ 3.25$.

*Improved Telephone. An improvement on Carter's Telephone for purity and uniformity of habits, bearing in great/abundance large, darkgreen pods containing peas of fine flavor, height 4 feet.

Pkt. 20c., 1 lb. 35c., 2 lbs. 60c., 7 lbs. $\$ 1.75,14$ lbs. $\$ 3.25$.

*Champion of England. A well-known and popular late variety, of excellent flavor and very productive; height 4 to 5 feet.

Pkt. 20c., 1 lb. 35c., 2 lbs. 60c., 7 lbs. \$1.75, 14 lbs. $\$ 3.25$. 


\section{SEED POTATOES}

Eight to ten bushels will plant one acre. One peck will plant 75 hills.

Potatoes are sent by express or freight, purchaser paying charges.

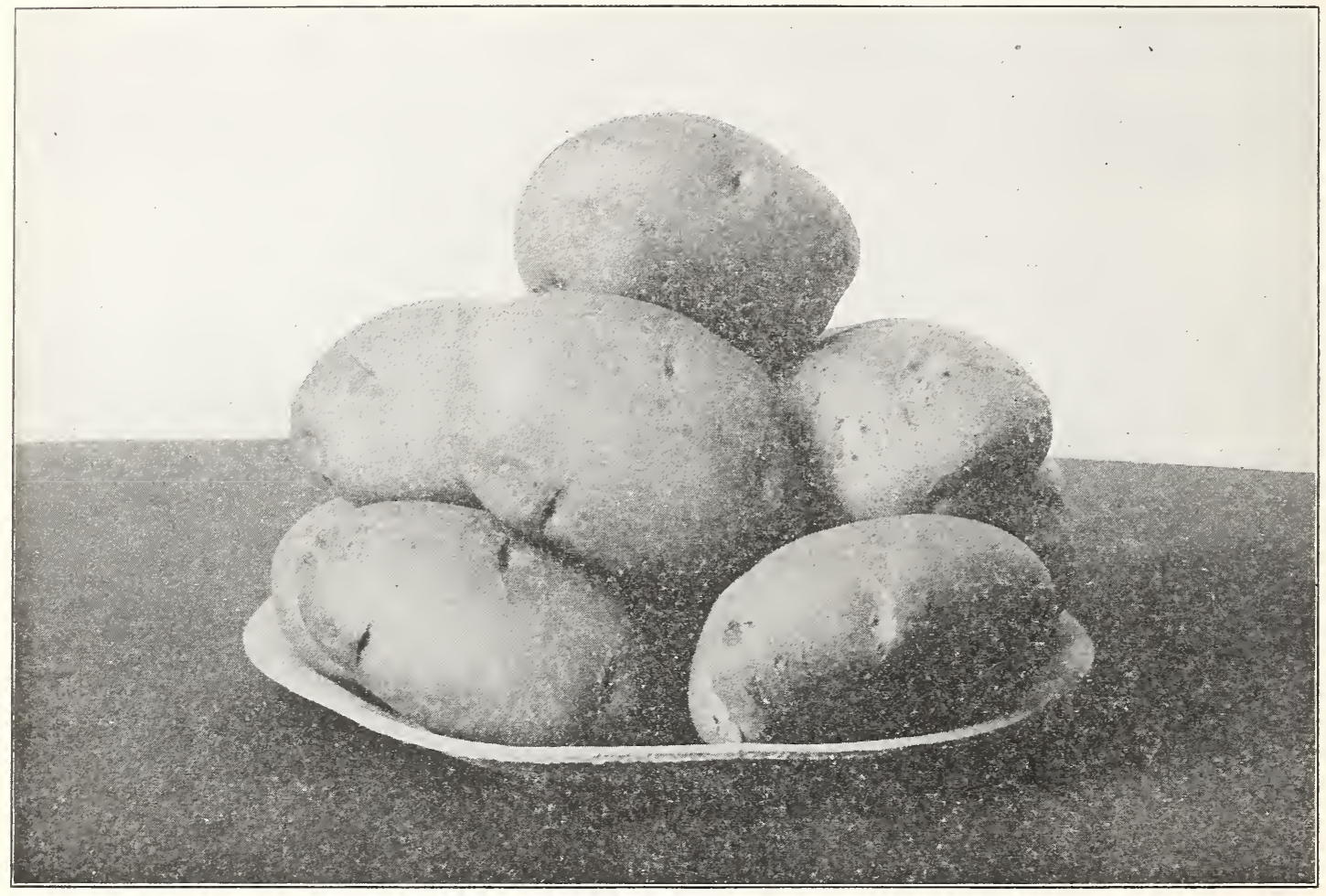

\section{We offer particularly fine strains of Early Rose, Irish Cobbler, Green Mountain and New Delaware Seed Potatoes. Write for prices.}

\section{PUMPKIN}

Same cultivation as for squash. hills.

One ounce will plant 20 hills; one pound will plant 250

Connecticut Field. Very productive, usually grown in fields with corn for feeding stock.

Pkt. 10c., 0z. 15c., 1/4 lb. 35c., lb. $\$ 1.00$.

King of the Mammoths. The best mammoth pumpkin, flesh is a golden-yellow, a splendid keeper and valuable for stock feeding.

Pkt. 10c., 0z. 15c., 1/4 lb. 45c., lb. $\$ 1.50$.

Mammoth Tours. Very large size, oblong in shape, largely used for feeding stock.

Pkt. 10c., 0z. 15c., 1/4 lb. 45c., lb. \$1.50.

Small Sugar. Very sweet and fine grained, a good keeper, best sort for family use.

Pkt. 10c., oz. 15c., 1/4 lb. 40c., lb. \$1.25.

\section{SALSIFY}

(Vegetable Oyster)

One of the most delicious and nutritious of vegetables.

Sow early in the spring in drills 14 inches apart and 1 inch deep. Cultivate the same as for carrots and parsnips. They can be left in the ground until spring.

One ounce to 50 feet of drill.

Mammoth Sandwich Island. This variety grows to a large size and is superior in quality to the Long White. Pkt. 10c., oz. 20c., 1/4 1b. 70c. 


\section{RADISH}

The seeds should be sown in light, rich, sandy loant For an early supply, sow in a hotbed in rows 4 inches apart. Sow in the open ground as soon as the ground can be worked in rows 8 to 12 inches apart $1 / 2$ inch deep. If the radish makes rapid growth it will be crisp and tender. Sow every week or ten days for succession.

One ounce for Ioo feet of drill.

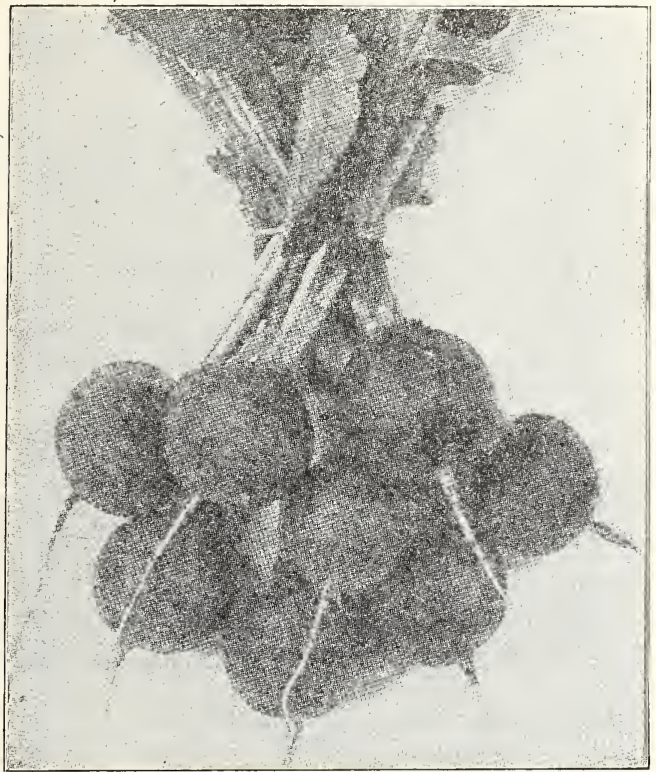

SCARLET GLOBE RADISH

Crimson Giant. An extra early, turnip-shaped variety, growing very large yet never pithy, always hard and solid; good for forcing and equally as good if grown in the open ground.

Pkt. 10c., oz. 15c., 1/4 lb. 40c., lb. \$1.25.

Early Scarlet White-Tipped. Small, round, red, short tops, crisp and tender.

Pkt. 10c., oz. 15c., 1/4 lb. 40c., lb. \$1.25.

Non Plus Ultra. The earliest forcing variety, round, red maturing in about twenty days.

Pkt. 10c., oz. 15c., 1/4 lb. 40c., lb. \$1.25.

Scarlet Globe. One of the best varieties for foreing or sowing in the open ground; globe shaped, scarlet color, crisp and tender.

Pkt. 10c., oz. 15c., 1/4 lb. 40c., lb. \$1.25.

French Breakfast. Oblong shaped, color scarlet, whitetipped, rapid grower, mild and tender.

Pkt. 10c., oz. 15c., 1/4 lb. 45c., lb. \$1.25.

White Icicle. Finest white radish. It is long, slender, pure white, roots of excellent quality. Fine for forcing.

Pkt. 10c., oz. 15c., 1/4 lb. 40c., lb. \$1.25.

White stuttgart. A turnip shaped, white radish, growing to large size; fine quality.

Pkt. 10c., oz. 15c., 1/4 lb. 45c., lb. \$1.50.

Long Black Spanish. A good winter variety. Pkt. 10c., oz. 15c., 1/4 lb. 40c., lb. $\$ 1.25$.

\section{SQUASH}

Squash are quite tender and should not be planted until the ground has become thoroughly warm and all danger of frost is past. Plant in light, rich suil, well pulverized. Bush varieties should be planted about 4 feet apart and the running varieties about 8 feet.

Bush varieties, one ounce to 40 hills; running varueties, one ounce to I5 hills, three to four pounds per acre. acre.

Early Giant Summer Crookneck. A desirable table sort, of dwarf, bushy habit, and very productive; the flesh is thick, yellow and of fine quality. One of the best market varieties.

Pkt. 10c., 0z. 15c., 1/4 lb. 45c., lb. $\$ 1.25$.

Mammoth White Bush Scallop. Pure white, producing large, thick fruit of fine flavor, early and productive. Pkt. 10c., oz. 15c., 1/4 lb. 45c., lb. \$1.25.

Delicious. Fine grained, sweet and dry, no other squash can equal it in sweetness and richness of flavor. In shape and color it is similar to the Hubbard. Weighs from five to ten pounds.

Pkt. 10c., 0z. 20c., 1/4 lb. 65e., lb. \$2.00.

Early Prolific Marrow. The earliest of the running varieties, maturing ten days earlier than the Boston Marrow; color a bright orange red; keers well. Pkt. 10c., oz. 15c., 1/4 lb. 50c., 1b. \$1.50.

Boston Marrow. A standard fall variety of a bright yellow color, an excellent sort for pies and largely used by canners.

Pkt. 10c., oz. 15c., 1/4 1b. 50c., lb. \$1.50.

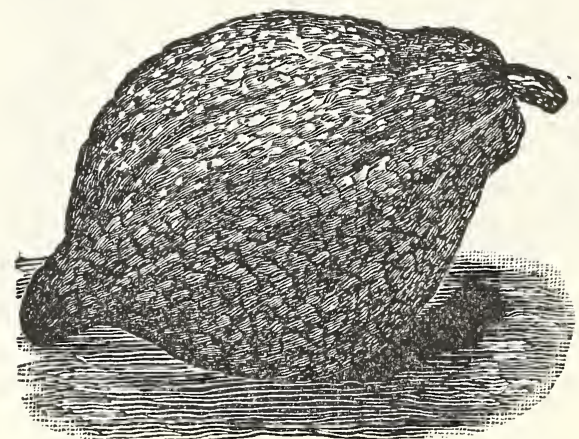

HUBBARD SQUASH

Hubbard (Cape Elizabeth grown). 'I'he standard winter squash, more largely grown than any other late variety, dark green skin and rich flesh, an excellent keeper. Pkt. 10c., oz. 20c., 1/4 1b. 50c., lb. \$1.75.

Golden Hubbard. Same type as the Green Hubbard but of rich orange red color and earlier to mature.

Pkt. 10c., oz. 20c., 1/4 lb. 50c., lb. \$1.75.

Blue Hubbard. Flesh fine-grained, dry and of excellent flavor, a good keeper.

Pkt. 10c., 0z. 30c., $1 / 4$ lb. 90c., lb. $\$ 3.00$.

Vegetable Marrow, English. The fruit should be eaten when less than half grown; color creamy white, flesh white. Pkt. 10c., oz. 20c., 1/4 lb. 50c.

Vegetable IMarrow, Italian. Oblong, skin dark green at first, but changes to a lighter green as it matures. Excellent quality. Pkt. 10c., oz. 20c., 1/4 lb. 50c. 


\section{SPINACH}

Sow early in the spring in drills one foot apart, covering the seed one inch deep, thinning out as it grows. For a succession sow every two weeks. For winter and early spring use, sow in August; cover with straw on the approach of severe cold weather.

One ounce to 50 feet of drill; ten to twelve pounds to the acre.

King of Denmark. The leaves are dark green, very thick and crumpled, and of good quality. Remains in good condition two to three weeks longer than any other variety before running to seed.

Pkt. 10c., 0z. 15c., 1/4 lb. 25c., 1b. 70c.

Round Thick-Leaved. A large, dark-green, thick-leaved variety; stands a long time before running to seed. Pkt. 10c., oz. 15c., 1/4 lb. 25c., lb. 60c.

Victoria. A variety of dense foliage, leaves thick and of a dark green color.

Pkt. 10c., oz. 15c., 1/4 lb. 25c., lb. 60c.

Long Season. A dark-green crumpled variety which withstands the hot weather without shooting to seed for a long time; very desirable for spring planting and of excellent quality.

Pkt. 10c., 0z. 15c., 1/4 lb. 25c., lb. 60c.

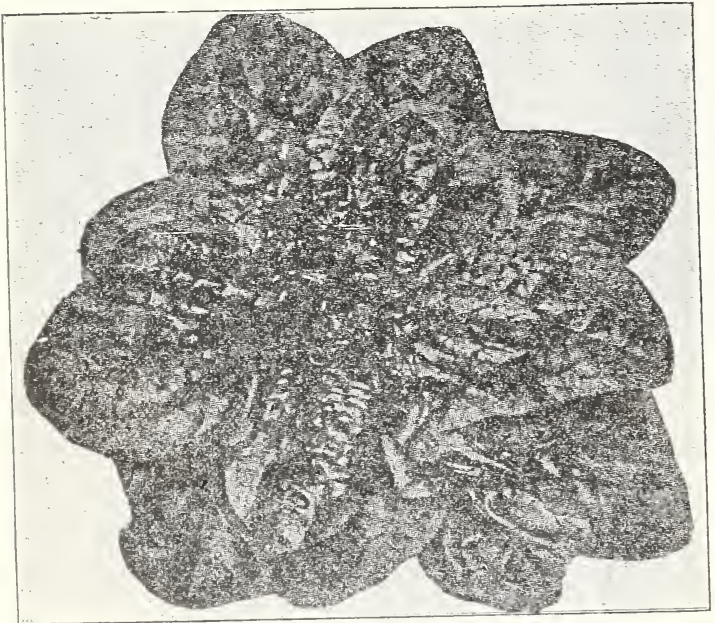

KING OF DENMARK

Bloomsdale. A very hardy variety; large thick, crumpled leaves, a favorite with Market Gardeners. The best for early spring or fall.

Pkt. 10c., oz. 15c., 1/4 lb. 25c., 1b. 60c.

Prickly or Winter. The hardiest variety for fall planting. Pkt. 10c., oz. 15c., $1 / 4$ lb. $25 \mathrm{c}$., lb. 60c.

New Zealand. A plant of branching habits which stands drought. Soak the seeds in warm water before planting. Plants should not be closer than 2 feet apart each way. Pkt. 10 c., 0z. 15c., 1/4 lb. 45c., lb. $\$ 1.00$.

"'Sterling Quality" Seeds are the highest grade obtainable and intended for the particular market gardener, florist and individual.

SEND US YOUR MAIL ORDERS

\section{TOMATO}

Sow the seeds about the first week in March in a hotbed, greenhouse or in shallow boxes in a window. When the plants are about three inches high transplant to cold frames, setting the plants about 4 inches apart or in pots singly. Transplant to the open ground when all danger of frost is past. Set in rows 4 feet apart each way, using a shovelful of rotten manure in each hill.

One ounce will produce about I,500 plants.

Our Tomato Seeds are grown from selected Stocks.

"John Baer." An extra early variety of superior merit. It produces perfect, solid high crown, beautiful, brilliant red tomatoes, is almost seedless, and has a mild, deliciously sweet flavor. Uniform in size and ripening. A valuable variety for the market or home garden.

Pkt. 10c., 1/4 oz. 20c., 0z. 50c., 1/4 lb. $\$ 1.50$.

Abbotts Early Red. A deep blood red variety. Foliage and vine medium. The fruit is smooth, uniform and of excellent flavor and quality.

Pkt. 10c., 1/2 oz. 30c., 0z. 50c.

Earliana. The best extra early variety. It is the earliest large tomato; color bright red, growing in clusters of medium size, smooth, solid, and of fine flavor; excellent for the market and home garden. Pkt. 10c., 1/2 oz. 20c., 0z. 35c., 1/4 lb. $\$ 1.00$.

Bonney Best. Early and prolific; fruit is smooth, round scarlet, of fine flavor.

Pkt. 10c., 1/2 oz. 20c., oz. 35c., 1/4 lb. $\$ 1.00$.

Early Detroit. Fruit very smooth, uniform in size, nearly globe shaped, firm and of excellent quality; color purplish pink; vine vigorous and productive. Pkt. 10c., 1/2 oz. 20c., oz. 35c., 1/4 lb. $\$ 1.00$.

Stone. The most reliable of the main crop, very large, bright scarlet, smooth, solid and very productive; is a good shipper.

Pkt. 10c., 1/2 oz. 20c., 0z. 35c., 1/4 lb. $\$ 1.00$.

Dwarf Stone. Dwarf and compact growing, plant resembling Dwarf Champion but is of a stronger growth, yielding a large crop of very smooth, solid tomatoes of the finest quality, color bright scarlet. Pkt. 10c., 1/2 oz. 20c., oz. 35c., 1/4 lb. $\$ 1.00$.

The Burbank. An extra early variety. Pkt. 10c., oz. $\$ 1.00$.

Ponderosa. One of the largest varieties, flesh solid and of fine quality.

Pkt. 10c., 1/2 0z. 20c., oz. 35c., 1/4 lb. $\$ 1.00$.

Red Pear. Pear shape scarlet fruit used for pickling. Pkt. 10c., 1/2 oz. 20c., oz. 35c.

Yellow Pear. Bright yellow, best for preserving. Pkt. 10c., 1/2 0z. 20c., 0z. 35c.

Strawberry or Husk. The small yellow fruit grows in a husk, used for preserving.

Pkt. 10c., 1/2 oz. 25c., 0z. 40c. 


\section{TURNIP}

Turnips do best in rich, light, sandy soil. For early use, sow in the spring as soon as the ground can be worked in drills 1 foot apart. Cover $1 / 2$ inch deep. Thin plants to 6 inches apart. For a succession, sow every two weeks until August. Rutabagas are usually sown broadeast, but larger crops are obtained if the seed is sown in drills 18 inches apart and thinned out to 8 or 10 inches in the rows. Sow from June to the middle of July.

One ounce will sow I50 feet of drill; one to two pounds to an acre.

Early Purple Top Milan. One of the earliest flat turnips; flesh solid and of good quality.

Pkt. 10c., 0z. 20c., 1/4 lb. 60c., lb. $\$ 2.00$.

Early White Milan. Extra early; roots of medium size, pure white, sweet and tender. It is a rapid grower and desirable for early use.

Pkt. 10c., oz. 20c., 1/4 lb. 60c., lb. $\$ 2.00$.

Purple Top White Globe. An early variety, of superior quality, globe-shaped, white flesh, tender and sweet, one of the best for table use.

Pkt. 10c., oz. 15c., 1/4 lb. 40c., lb. $\$ 1.00$.

Red Top White Globe. It contains all the good points of the Purple Top White Globe and has the added feature of having a bright red top making it very attractive in appearance.

Plkt. 10c., oz. 15c., 1/4 lb. 40c., lb. $\$ 1.00$.

White Egg. A pure white, egg-shaped variety of rapid growth; flesh firm, sweet and mild.

Pkt. 10c., oz. 15c., 1/4 lb. 40c., lb. $\$ 1.00$.

Golden Ball. Very early, fine quality and of excellent flavor.

Pkt. 10c., oz. 15c., 1/4 lb. 40c., lb. $\$ 1.00$.

Cow Horn or Long White. A very productive, quickgrowing turnip, carrot-like in form, growing nearly half out of the ground.

Pkt. 10c., oz. 15c., 1/4 lb. 40c., lb. $\$ 1.00$.

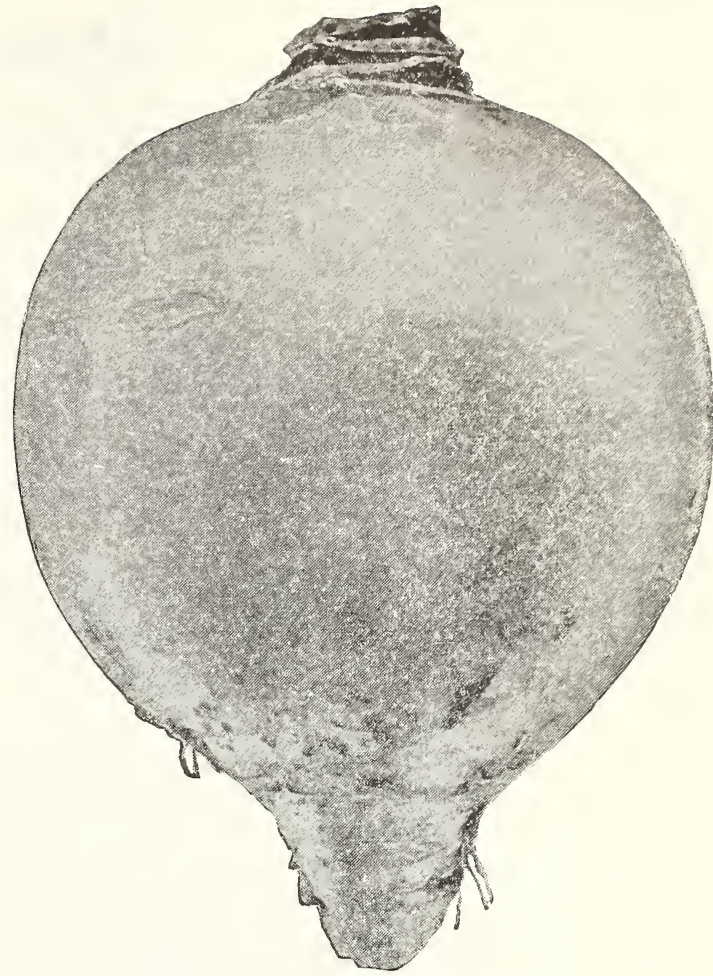

PERFECT MODEL RUTABAGA

Perfect Model. An improved strain of the finest yellow-fleshed rutabaga, remarkable for uniform shape and fine quality, very sweet and tender and a good keeper.

Pkt. 10c., 0z. 20c., 1/4 1b. 50c., 1b. \$1.25.

American Purple Top. Very hardy, productive, and a good keeper; flesh yellow and solid, a fine variety for table use.

Pkt. 10c., oz. 15c., 1/4 lb. 40c., lb. $\$ 1.00$.

Millpond Purple Top Swede. An imported strain of Purple Top Ruta Baga, very smooth and uniform shape. Excellent keeper.

Pkt. 10c., 1/4 lb. 35c., 1 lb. $\$ 1.00$.

Improved Long Island. Undoubtedly one of the finest $\mathrm{va}$ rieties of purple-top Ruta Baga. Leaves few and small; bulbs fine shaped with very short, small necks; purple crown, skin and flesh bright yellow, solid, sweet and mild flavor.

Pkt. 10c., oz. 15c., 1/4 lb. 40c., 1b. $\$ 1.00$.

\section{SWEET AND MEDICINAL HERBS}

Sow in the spring in shallow drills, 1 foot apart; when up a few inches thin out to proper distances, or transplant; cut the herbs when in flower, tie them up in small bunches and hang in the shade to dry.

Anise Annual
Balm Perennial
Basil, Sweet Annual
Caraway Biennial
Catnip Perennial
Dill Biennial
Fennel, Sweet Perennial

\section{Anise Annual}

Per oz. 25c., pkt. 10c. Lavender Perennial

Per oz. 30c., pkt. 10c. Marjoram, Sweet Annual

Per oz. 25c., pkt. 10c. Mint Perennial

Per oz. 25c., pkt. 10c.

Per oz. 60e., pkt. 10e.

Per oz. 20c., pkt. 10c.

Per oz. 20c., pkt. 10c.
Per oz. 40c., pkt. 10e. Per 0z. 30c., pkt. 10c. pkt. 25c.

Sage Anmual

Summer Savory Annual Thyme Perennial
Per oz. 50c., pkt. 10c. Per oz. 30c., pkt. 10c。 Per oz. 50c., pkt. 10c。 


\section{FIELD CORN}

Plant eight to ten quarts per acre in hills, one to one and one-half bushels broadcast, one bushel in drills.

EARLY EIGHT-ROWED YELLOW FLINT. This corn is grown right here in Maine and is the earliest yellow variety we know of. It matures in ninety days and the ears are long with small cob filled to the tip with large broad kernels.

We cannot recommend this corn too highly for either Grain or Ensilage. Price on application.

Early Wonder Dent. A rariety of great value. Heretofore, earliness in seed corn has meant that the growth would be small; and a corn that produced hearily usually could not be depended upon to reach maturity in an ordinary season in this section. Price on application.

Mortgage Lifter. A heavy yielding, Yellow Dent Corn. Stocks are quite tall and furnish a large amount of fodder which contains a good percentage of grain. The ears are 8 to 10 inches in length, and from 12 to 16 rows. Price on application.
Genuine Eureka Ensilage. The corn that grows more ensilage to the acre than any other variety. It grows very tall, attaining a height of 12 to 15 feet and makes a heavy thick growth of fodder. Try this variety if you want the maximum tonnage. Price on application.

Ieaming Early Dent. A yellow Dent variety very valuable for ensilage. The plants are tall with a large amount of foliage. Each stalk usually produces two good long ears with small red cobs, well filled with large, deep golden kernels. Price on application.

Sweet Fodder Corn. For soiling or ensilage. Some dairymen prefer the sweet fodder corn to the ordinary ensilage variety, and although it does not make as large a stalk, nor as much foliage, it is highly relished by stock. It does best when sown in drills at the rate of 2 bushels to the acre. Price on application.

\section{STANLEY'S CROW REPELLENT.}

Saves replanting, prevents crows, other birds and animal pests from pulling corn. Protects corn from rot caused by moisture. Makes seed germinate faster. Does not clog planter. Large can, enough for two bushels of seed corn, $\$ 1.50$. Small can, enough for one bushel, $\$ 1.00$.

\section{GRAINS AND FARM SEEDS}

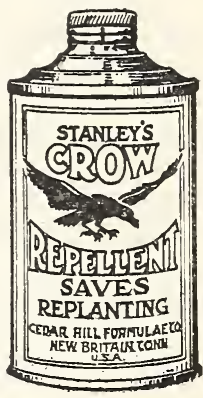

\section{PRICES SUBJECT TO CHANGE WITHOUT NOTICE}

Prices do not include delivery. Add cost of bags when ordering, as follows: $1 / 2$ bush., 10 cents; 2 bush., 50 cents.

Spring Wheat, Marquis. (Beardless.) An early and productive variety. The kernel is flinty, darker red and more plump than Rer Fife and matures a week to ten davs earlier; weight 64 to 66 lbs. per measured bushel. Write for price.

Buckwheat (Japanese.) The best and most profitable variety. It is earlier and more productive than the Silver Hull. Write for price.

Fungarian. A popular annual used for hay and forage, yielding two to three tons per acre. Sow 1 bushel to the acre. Weight 48 pounds per bushel. Write for price.

Japanese Millet. A forage plant of excellent quality, growing 6 to 8 feet in height, and yielding 10 to 15 tons per acre. Sow 20 lbs. per acre broadcast, 15 lbs. in drills 18 inches apart. Write for price.

Soja Beans. Valuable as a forage crop or green manure: also as a green fodder and silo plant. Early Dwarf Green. An early maturing variety. Write for price.

Winter Vetch. Suitable for both spring and autumn seeding, and if intended to stand orer the winter, they should be sown as long before winter as possible to enable them to become established firmly.

Canada Field Peas. A valuable crop for soiling and for cattle feed. Sow 21/2 bushels per acre-if sown with oats, nse one and nne-half bushels each of the oats and peas. Trite for price.
Storm King Oats. One of the earliest, heaviest and most prolific domestic-grown seed oat in cultivation. The heads measure from 8 to 10 inches and the kernels are of immense size, thick, plump and heary.

Price $\$ 1.50$ per bushel.

Maine $3 \pm 0$ Oats. This variety makes a strong growth of straw. The heads are large and bushy, yielding large crops of oats of fine quality.

Price $\$ 1.50$ per bushel.

Northerm White Oats. On account of their low price this oat is used extensively for fodder, but will show very good results when cut for grain.

Price $\$ 1.10$ per bushel.

Barley, Beardless. Early, hardy and productive. Write for price.

Winter Rye (Rosen.) Rosen Rye produces a strong vigorous straw and stools to a remarkable degree. The grain is large, plump, heavy and beautiful color. Owing to its vigorous stooling property, less seed is required per acre. Write for price.

DWarf Essex Rape. A forage plant of great value, furriching rich pasturage for sheep, hogs or cattle within six weeks from the time of sowing. It also makes splendid green feed for poultry. Sow $8 \mathrm{lbs}$. per acre broadcast, 4 lbs. per acre in drills. Write for price. 


\section{"Sterling Quality"}

\section{GRASS AND CLOVER SEEDS}

NOTE-“Sterling Quality" Timothy and Clovers are Northern grown, domestic seed, especially adapted to the climate of New England.

You will find our "Sterling Quality" brand farm seeds the very highest in tests as to purity and germina tion. We do not carry the so called "medium grades" which might be purchased at a slightly cheaper price, The best, or "Sterling Quality" gives the greatest satisfaction to you and to us.

\section{Prices Subject to Market Changes}

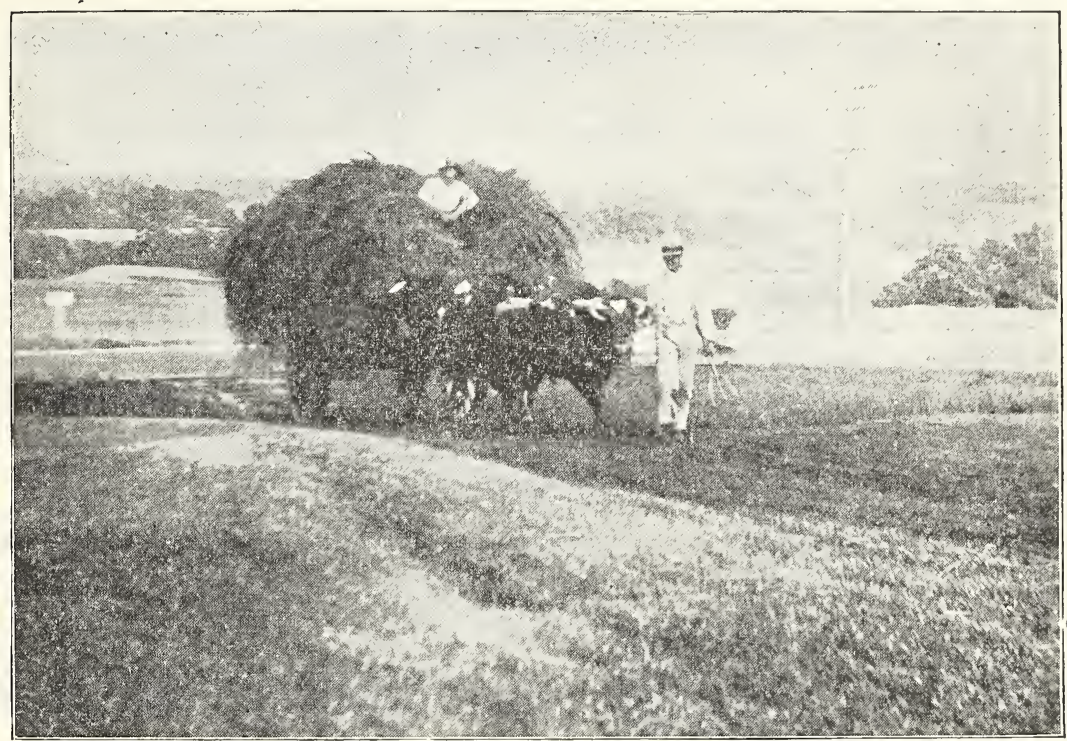

Haying with oxen at Yarmouth Foreside

\section{SPECIAL QUOTATIONS WITH SAMPLES ON APPLICATION}

Timothy, or Herd's Grass ("Sterling Quality' '). Perennial. Roots are fibrous in moist soils, but in dry soils often become bulbous; blooms in June and July. While this grass is commonly known as Timothy, it is frequently called Herd's Grass. It is the most valuable grass for hay, especially in the North, thriving best on moist, loamy soils of medium tenacity.

Red Top, Fancy Recleaned. ("Sterling Quality"). Root-creeping; perennial; flowers in July. This valuable grass has been commonly cultivated in our fields for over a century. It is a fine permanent grass, and forms a nutritious pasturage when fed close. It is valuable for all wet soils, producing a large return in good hay.

Kentucky Blue Grass. Root-creeping; perennial; flowers in June. This valuable grass is very common in the soils of America, and is excellent for pastures. It is a very valuable species in lawn mixtures.

Orchard Grass. Root fibrous, perennial, flowers in June and July. This in one of the most valuable and widely known of all the pasture grasses.

\section{CLOVERS}

Clovers are the foundation of permanent agrieulture in the North and East. They have the faculty off taking nitrogen from the air, and also of rendering available much of the inert plant food of the soil. Their long, powerful tap-roots penetrate to a great depth, loosen the soil, admit air, and by their decay add immensely to the fertility of the soil.

Red Clover. ("Sterling Quality.") This is the common Red Clover and by far the most important variety for the practical purposes of agriculture.

Alsike Clover. ("Sterling Quality.") The hardiest of all clovers; it resists cold and extreme drought, and for low, wet land is most valuable; excellent for bees.

A]falfa Clover. Valuable as hay and forage crop.

Sweet Clover, Bokhara. Used as a soil-improving crop.

White Clover. Largely used in lawn and pasture mix. tures. 


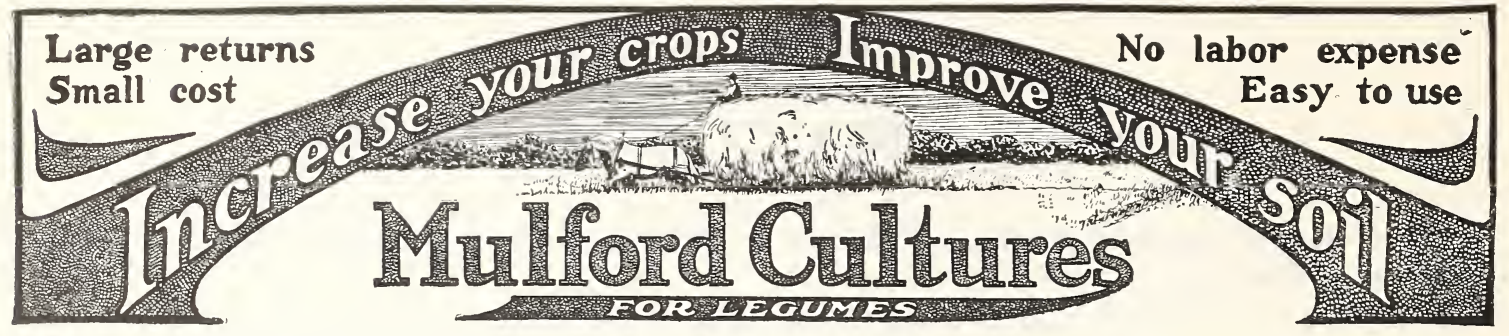

Mulford Cultures contain pure, tested strains of active, vigorous nitrogen-fixing bacteria, for inoculating seeds of legumes or soil.

Mulford Cultures are scientifically prepared and tested with the utmost care and skill. Enormous numbers of these very valuable and desirable bacteria are thus available to you in every package of Mulford Culture and may readily be applied to your seed. The sealed bottle insures purity.

Legumes offer the best known means of maintaining soil fertility and rejuvenating over-cropped and wornout fields. They add both humus and nitrogen to your soil and thus increase your yield of wheat, cotton, corn and other non-legume crops.

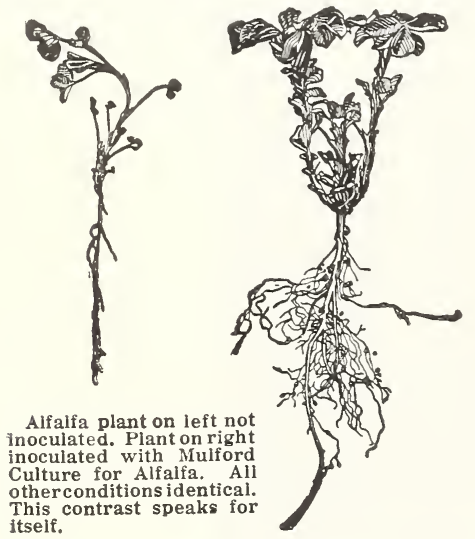

Always specify on your order what crop you want to inoculate.

$\begin{array}{llll}\text { ALFALFA } & \text { ALSIKE CLOVER } & \text { VETCH } & \text { LIMA BEANS } \\ \text { CRIMSON CLOVER } & \text { BURR CLOVER } & \text { VELVET BEANS } & \text { LESPEDEZA } \\ \text { SWEET CLOVER } & \text { COW PEAS } & \text { SWEET PEAS } & \text { BEGGAR WEED } \\ \text { RED CLOVER } & \text { SOY BEANS } & \text { GARDEN PEAS } & \text { and others } \\ & \text { PEANUTS } & \text { GARDEN BEANS } & \end{array}$

Prices for Mulford Culture Concentrates

For small seeds, Alfalfa, Clovers, etc. For large seeds, Soy Beans, Cow Peas, etc.

10 bushel size .........\$8.00 20 bushel size ..........\$8.00

$21 / 2$ bushel size ...........2.25 5 bushel size ........... 2.25

1 bushel size .......... $1.00 \quad 2$ bushel size ............ 1.00

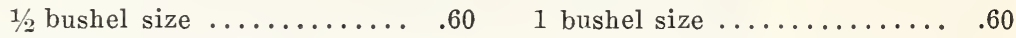

Garden size (composite culture for Garden Beans, Garden Peas, Lima

Beans and Sweet Peas) $\ldots \ldots \ldots \ldots \ldots \ldots \ldots \ldots \ldots \ldots \ldots \ldots \ldots . . . \ldots \ldots$

Free Descriptive Folder sent upon Request

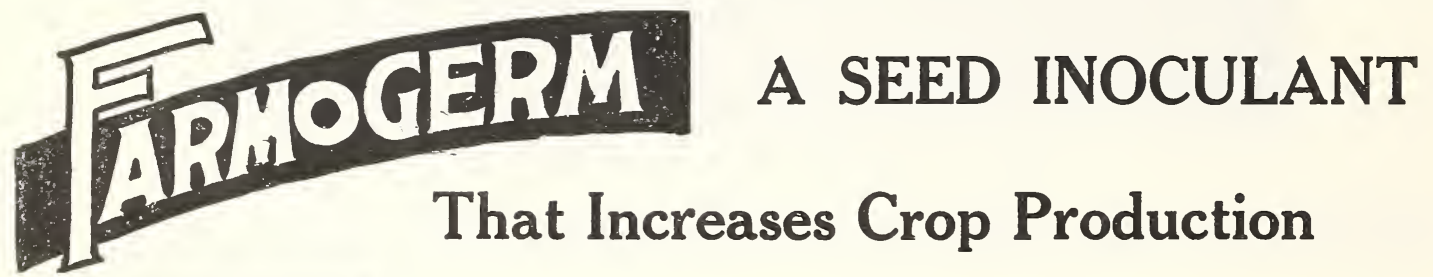

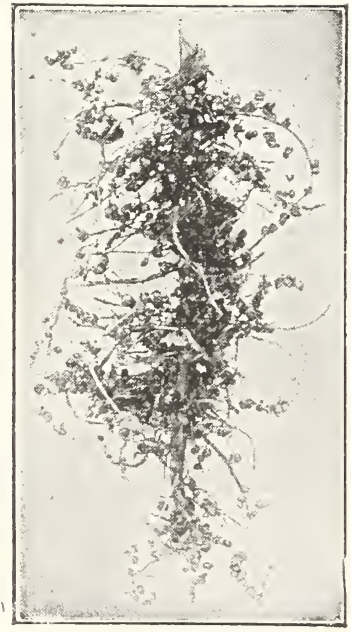

Roots like this mean bigger yields-better soil.
Soil and crop experts agree that for best growth, and to put atmospheric nitrogen in the soil, it will pay all farmers to inoculate all legumes, even where they are at present successfully grown. The cost is trivial when compared with the profit it will bring you. Legumes are clovers, peas and beans, alfalfa, soy beans, vetches, and other plants that grow their seeds in a pod. Their roots are the home of bacteria that draw fertility-building nitrogen from the air and store it in swellings on the roots, called nodules. These nodules not only feed nitrogen to the crop they are on, but rot away in the ground and supply valuable nitrogen to the soil for future crops. The one-acre size bottle is sufficient for 15 pounds of clover, 20 pounds of alfalfa, 100 pounds of Canada Field Peas, 60 pounds of Vetch, etc. A different bacteria is required for each crop. When ordering, be sure to state what crops you wish to inoculate.

A special composite culture is prepared for peas, beans, and sweet peas, $1 / 4$ acre size only. You'll get more peas and beans, and larger sweet peas by using this. Ask for No. 5, price 50c.

Farmogerm prices are: 1 -acre size, $\$ 1.00 ; 3$-acre size, $\$ 2.50$;

12 -acre size, $\$ 9.00$. Full directions accompany each bottie. 


\section{"Sterling Quality" CHOICE FLOWER SEEDS}

ANNUALS (for Perennials see pages 37-38)

\section{General Directions For Cultivation}

A rich, sandy loam is the best for most flowering plants. The soil of a good garden should be deep, well pulverized, and if fertilizers are used they should be thoroughly mixed with the soil.

It is best in practically all instances except hardy annuals to start the seed in boxes, preferably a box about $18 \times 24$ inches and 4 inches deep, using very andy soil with leaf-mold that will not bake, and provide for drainage by boring some holes in the bottom of the box. It is best not to put any fertilizer in the seed box, since it is necessary to bring the plants to the third or fourth leaf, when they should be pricked out and reset in another box, in which the oil should be loam mixed with leaf-mold. It is important that the plant be of good size, strong and sturdy, when finally transplanted in the garden.

If the seed be sown directly in the garden, it should be sown in the spring sfter the soil is well worked and fertilized. When up, the plants must be thinned from two to twelve inches, depending on the variety, otherwise they will be weak and spindling. It is a mistake to leave plants too thick. A common mistake in sowing flower as well as other seeds is covering too deep. As a general rule, cover only to the depth of the thickness of the seeds, or with medium-sized seeds, like Balsams, Zinnias, etc., half an inch or less is the proper depth. Such fine seeds as Portulaca, Nicotiana, etc., need only to be pressed into the soil with a piece of board or palm of the hand. Always press the earth down firmly after sowing all flower seeds, else there is danger of their drying up before the roots can get firm hold of the soil. Seeds of the hardier annuls may be sow war it is preferable to transplant, as the plants are generally stronger and stand the preferable to transplant, as the plants are generally stronger and stand the
drought better. During very dry weather, and when the seedlings are first ot out. they should be watered frequently. Provide some support for all such snnuals as require it.

The weeds should be kept down and the ground loosened often, so that the plants will receive the full benefit of the rains and dews, which they will not if the ground is allowed to become hard and baked.

Per Pkt.

ACROCLINIUM. A half-hardy annual, bearing white and rosecolored flowers which are used when dried for winter bou-

quets. $11 / 2$ feet. Rose and white, mixed ...........\$0.10

AGERATUM. A beautiful, hardy annual. The flowers, which are produced in clusters, are very attractive in the garden and are very useful for bouquets.

Iittle Blue Star. Bright blue flowers, 6 inches..........

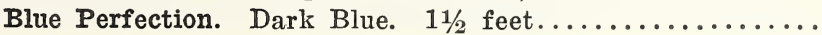

AIYSSUM. A fragrant, hardy annual, bearing spikes of small, white flowers in great profusion throughout the summer and autumn. Useful for borders and for cutting.

Sweet Alyssum. Flower small and sweet. ............ 50c. Iittle Dorrit. Pure white, very dwarf and sweet scented,

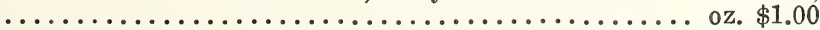
Lilac Queen. Of dwarf compact habit, with flowers of a

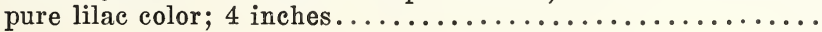

ANTIRRHINUM (Snapdragon.) A half-hardy perennial, easily raised from seed. Bloom profusely the first season from midsummer till fall.

\section{TALI, IAARGE FLOWERING VARIETIES}

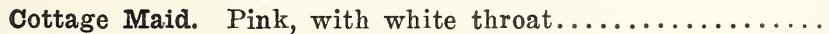

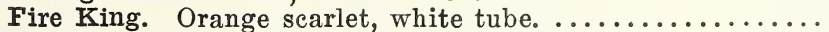

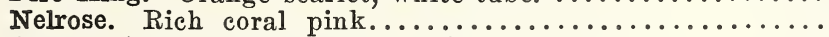

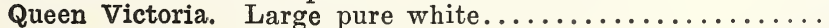

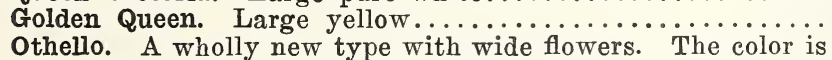

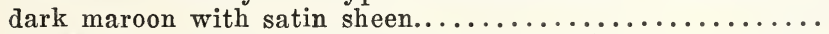
Silver Pink. A very beautiful shade of pink. ............ Large Flowering. Mixed colors............. 1/4 oz. 50c.

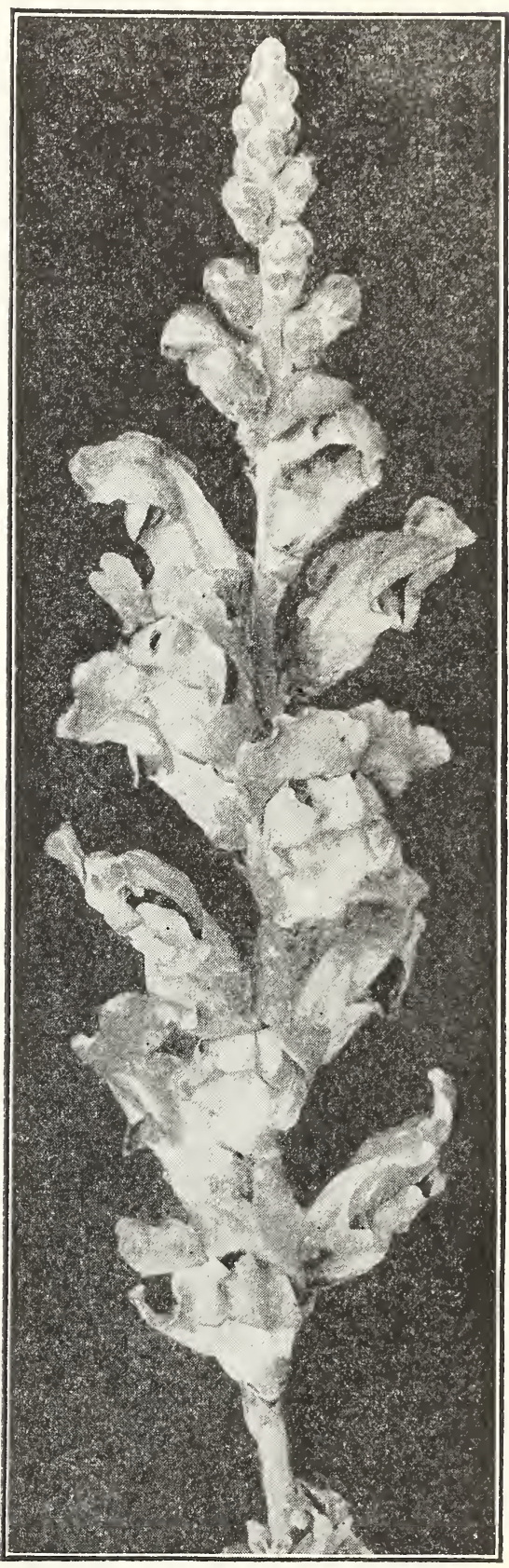

ANTIRRHINUM OR SNAPDRAGON

\section{FREE DELIVERY}

To any address in the United States on all Flower Seeds by the packet, ounce, half-pound, and pound. 


\section{ASTERS}

A popular half-hardy annual produced in a great variety of classes and an almost endless number of colors. The tallest varieties grow about two feet high and some varieties of dwarfs are not six inches high. The best method of culture is to sow the seed in boxes in March or April. Cover the seeds about one-fourth inch deep with rich, light soil, and when the plants have three or four leaves transplant about 15 inches apart each way. The seed can be sown in rows where the plants are to remain, thinning them from six to twelve inches apart, according to variety. One of the best annuals for cut flowers.

CAIIFORNIA GIANTS (NEW). A type characterized by the Beauty's vigorous growth and the Crego or Ostrich Feather type of flower. A true nonlateral type. The flowers are much larger and more substantial than the improved Crego, measuring 5 to 6 inches in diameter, and stand up well when shipped as cut flowers. Their immense size and beauty, as well as their long and sturdy stems make them very attractive when arranged in floral work-Peach BlossomLight Blue-Dark Purple-Deep Rose-Mixture of above. Per pkt. 20c. each, 3 pkt. $50 \mathrm{c}$.

\section{FARLY AND MEDIUM EARIY ASTERS}

Imperial Daybreak. Flowers very large and double; color a shell pink; height $2 \frac{1}{2}$ feet. Per pkt. 10c., 1/8 0z. 40c., 1/4 oz. 70c.

Imperial Purity. Similar to Daybreak in form and habit of growth; the blooms are pure white.

Per pkt. 10c., 1/8 oz. 40 c., 1/4 oz. 70 c.

Imperial Iavender. The form of the flower and the habit of the plant are identical with Daybreak, but the color is a delicate lavender.

Per pkt. 10c., $1 / 8$ oz. 40 c., $1 / 4$ oz. 70 c.

Tho Royal. An early flowering aster; the plants are of branching habit; the flowers are very double and are borne in great profusion on long stems. Mixed colors. Per pkt. 10c., 1/8 oz. 45 ., $1 / 4$ oz. $80 \mathrm{c}$.

Queen of the Market. One of the earliest blooming varieties. The plants are about 1 foot high, bearing from ten to fifteen finely formed flowers on long and graceful stems. White, light pink, lavender and mixed colors. Separate colors, or mixed.

Per pkt. $10 \mathrm{c} ., 1 / 8$ oz. $45 \mathrm{c} ., 1 / 4$ oz. $80 \mathrm{c}$.

\section{MID-SEASON AND LATE ASTERS}

Heart of France. This is one of the largest flowering of the very dark red sorts. The plants are nicely branched and the flowers grow on long strong stems. Height 2 feet.

Per pkt. $10 \mathrm{c} ., 1 / 8$ oz. $45 \mathrm{c} ., 1 / 4$ oz. $80 \mathrm{c}$.

Vick's Peerless Yellow. The most satisfactory yellow yet produced. The flowers are large and remarkably full and ball shaped, the plants of branching type and very vigorous. Pkt. 20c., 1/8 oz. 50c.

Astermum. A select strain of this new aster. The flowers are of immense size, with curled and twisted petals, closely resembling the blooms of Japanese Chrysanthemums. Mixed colors.

Per pkt. $10 \mathrm{c} ., 1 / 8$ oz. 50 c., $1 / 4$ oz. 85 c.

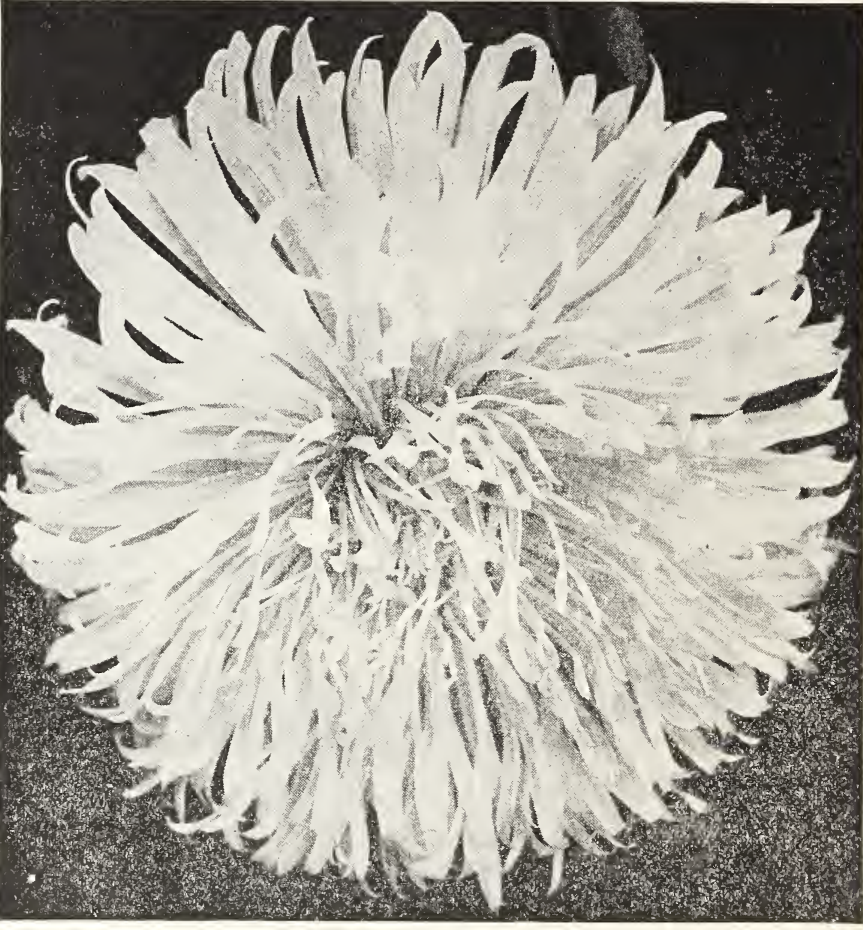

ASTERMUM

\section{MID-SEASON AND IATE ASTERS Cont'd}

Improved Giant Crego. One of the finest varieties of asters, flowers very large, often five inches across, with long, stout stems. Keep longer in good condition when cut than any other variety. Height $2 \frac{1}{2}$ feet. White, shell-pink, rose-pink, lavender, purple and mixed colors. Separate colors, or mixed.

Per pkt. 10 c., $1 / 8$ oz. 50 c., $1 / 4$ oz. 85 c.

Giant Comet Branching. The plants form strong, branching bushes 2 to $2 \frac{1}{2}$ feet high bearing on long, strong stems flowers which, under ordinary cutivation, average 5 inches across. White, shell-pink, rose pink, lavender, crimson, light blue and mixed colors. Separate colors, or mixed.

Per pkt. $10 \mathrm{c} ., 1 / 8$ oz. $50 \mathrm{c} ., 1 / 4$ oz. $85 \mathrm{c}$.

September Beauty. Delicate shell-pink. Per Pkt. .15

China Asters. General Mixture. A mixture of many sorts and colors blooming from early in the summer to late in the fall. Per pkt. 10c., $1 / 8$ oz. $35 \mathrm{c}$. 


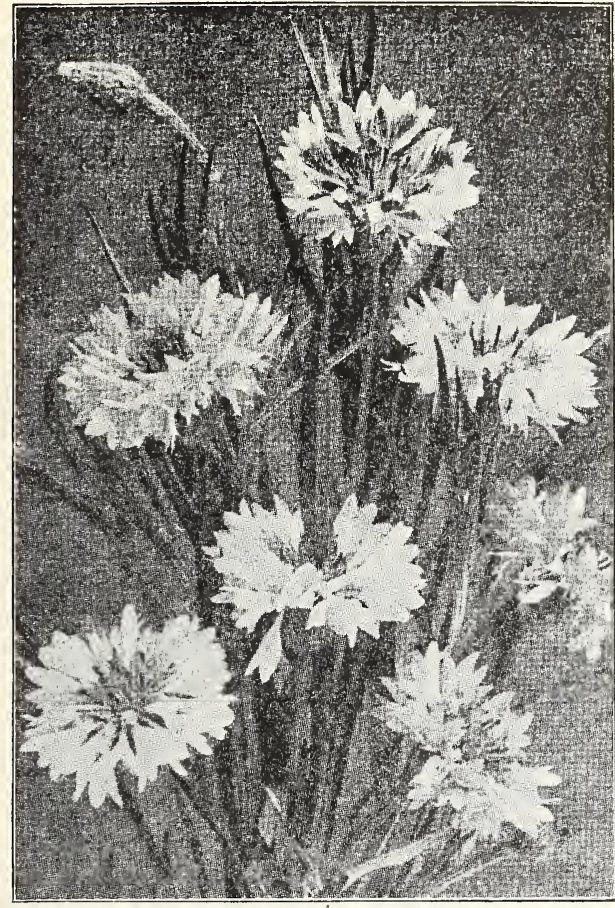

BACHELOR'S BUTTON

BACHELOR'S BUTTON. Hardy annual of easy culture, one of the most attractive of all the old fashioned flowers. Sow the seed where it is to remain and thin to six inches. Per Pkt. Single Blue .................... .10 Single Mixed Colors ...........1/ oz. 25c. .10 Double Mixed Colors ........... 1/2 oz. 35c. .10 Double Blue. Fine dark blue.....1/4 oz. 35c. .10

BAISAM. A favorite garden flower producing masses of beautiful, brilliant-colored, double flowers of easy culture; succeeds in a good rich soil; set the plants one foot apart; tender annuals: 2 feet.

Double Camellia-Flowered. Choice mixed... Double Rose-Flowered. Mixed colors

......................1/4 oz. 35c.

BEANS, Flowering. Popular ornamental climbers, 6 to 8 feet.

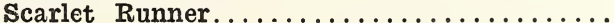

BROWAILIA. Very handsome, free-flowering plants. $11 / 2$ feet high.

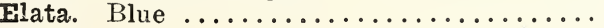

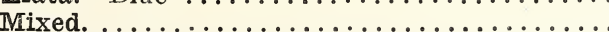

CANARY BIRD VINE. Half-hardy, climbing annual, bearing an abundance of bright yellow fringed flowers ............1/2 oz. $25 \mathrm{c}$.

CALENDULA. Profuse-blooming dwarf annuals; of easy culture and flowering until frost. Orange King. Double, dark orange red,

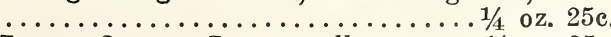
Lemon Queen. Lemon-yellow.......1/4 oz. 25c. Meteor. Yellow flowers, striped with or?nge. .......................1/4 0z. 25c. Mixed Varieties. ...........1/4 oz. $20 \mathrm{c}$.

CAILIOPSIS (or Coreopsis.) A hardy annual growing about 2 feet high, valuable for bright bedding effects or for cutting. Blooms from June until September.

Mixed colors. Fine Varieties .....1/4 oz. 25c.
CANDYTUFT. A hardy annual of easy culture and valuable for bedding or massing. Giant Hyacinth Flowered. Very large heads and long spikes of white flowers. 1 foot.

$\ldots \ldots \ldots \ldots \ldots \ldots \ldots \ldots \ldots$ 1/4 oz. 30c. .10

Crimson. 1 foot.................. 10

Flesh Pink. 1 foot................. 10

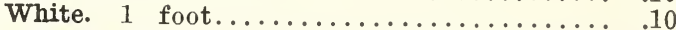

Mixed, all colors. 1 foot. Oz. 45 c., $1 / 4$ oz. $15 \mathrm{c} . \quad .10$

CARNATION. Carnations are general favorites for their delicious fragrance and richness of colors. They are indispensable, both for greenhouse culture in winter and for the garden in summer. The Marguerite type is the best for summer flowering.

Marguerite type

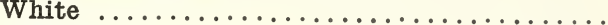

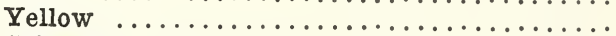

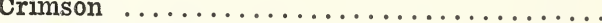

Mixed, all colors $\ldots \ldots \ldots \ldots \ldots \ldots \ldots \ldots \ldots \ldots$

Giant Chabaud. This is really a glorified type of French Carnation coming into bloom six months from time of sowing and continuing to bloom throughout the summer. Plants form ten to twenty stalks, bearing huge flowers of fine form, coming 90 per cent double.

Mixed.

CENTAUREA (Dusty Miller.) Half-hardy perennial, used for borders or edgings.

Candidissima. Silvery white foliage, deeply cut; about 1 foot high................. Gymnocarpa. Leaves silver gray, with graceful, drooping habit. $1 \frac{1}{2}$ feet...........

CHRYSANTHEMUM (Annual.) Summer-blooming annuals, growing 12 to 18 inches high. very effective for beds or cut blooms.

Single Mixed .............. 1/4 oz. 20c. Double Mixed ............... 1/4 oz. 20c. .10

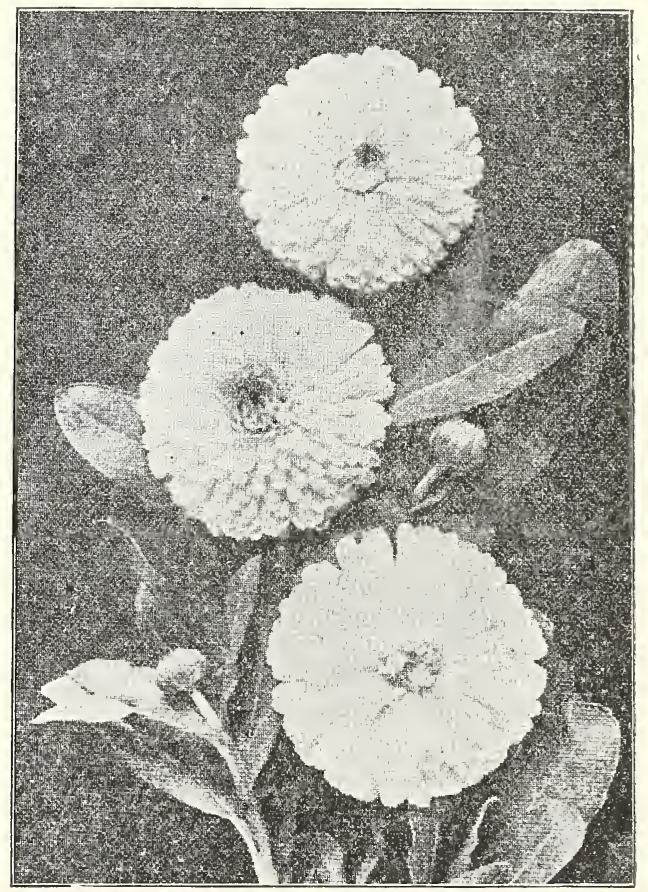

CALENDULA 
Per Pkt.

OLARKLA. Beautiful, hardy annuals with rosecolored, white and purple flowers in very brilliant shades. About $1 \frac{1}{2}$ to 2 feet high and profuse bloomers.

Single Mixed ............. 1/4 oz. 30 c. .10 Double Mixed .............1/4 oz. 30 c. .10

COBAEA. A rapid-growing climber, with handsome foliage and large bell-shaped flowers half-hardy perennial. $20 \mathrm{ft}$.

Scandens. Purple..........1/4 oz. 25 c.

OOCKSCOMB. Very popular annuals of the easiest culture, producing large, ornamental comb-like heads; useful both for summer bedding and pot plants.

Glasgow Prize. Brilliant, deep purplish-red combs, dark foliage. Height about 1 foot. . Finest Dwarf Mixed.

COLEUS. A tender perennial, growing about 10 to 18 inches high, and grown for its beautiful, bright-colored, velvety leaves.

Mixed Hybrids. Finest Mixed varieties...

CONVOLVULUS major (Morning Glory.) A handsome, showy climber of easy culture and suitable for covering windows, trellises, etc. The flowers are most brilliant in the morning and run through many shades from white to dark blue, red and striped. Hardy annuals 10 feet high.

Mixed Choice Colors .............. 25c.

cosmos. A very effective flowering plant, quite hardy and rapid growing, forming bush-like plants 4 to 6 feet high and covered with large, single, dahlia-like flowers. Start in March and transplant to open ground about June first.

Early Flowering, Mixed Colors..1/4 oz. 20c.

" " White ........ oz. 25c.

" " 6 Pink ........1/4 0z. 25c.

“ " Crimson ........1/4 oz. 25c.

Late Flowering. Giant mixed...... 1/4 oz. $25 \mathrm{c}$.

NEW EXTRA EARLY FLOWERING DOUBLE COSMOS. They grow to a height of about three feet, forming a perfect bush massed with bloom, bearing beautiful double flowers of good size on long stems; they come about seventy-five per cent double from seed. They bloom in seventy days from the day seed is sown, and continue until cut down by frost.

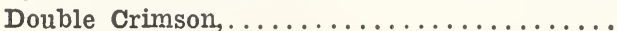

Double Pink,...................

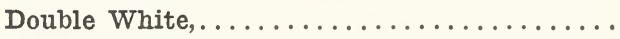

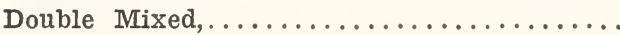

CYCLAMEN. A tender perennial for greenhouses and window gardens. Easily grown from seed. Sow in August or September.

Persicum Giganteum. Giant mixture......

CYPRESS VINE. A summer, climbing annual with fine, feathery foliage and pretty, starshaped flowers.

Scarlet

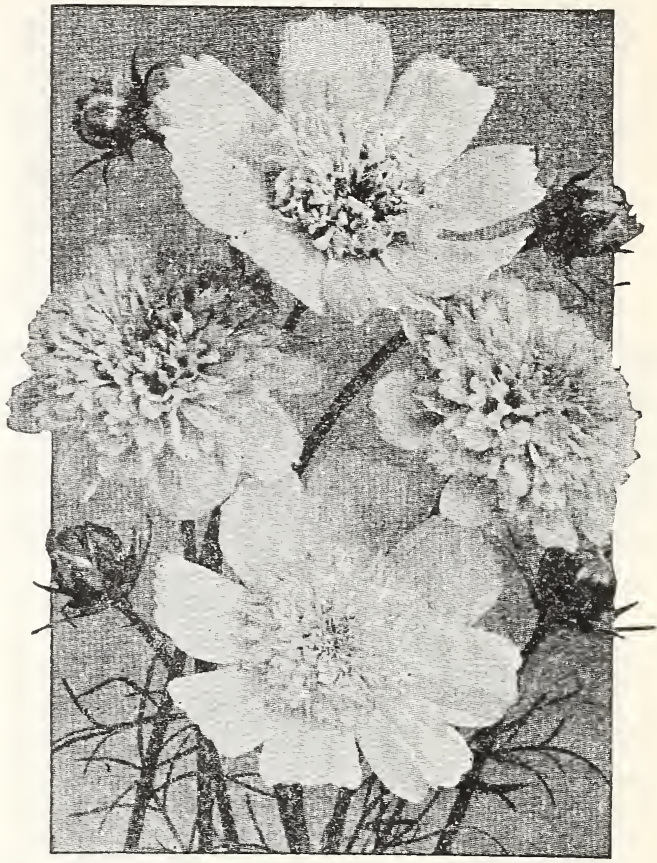

DOUBLE COSMOS

Per Pkt.

DATURA. Large, strong-growing plants with large, trumpet-shaped flowers. 3 feet.

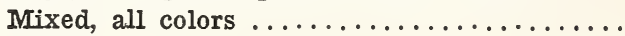

DIANTHUS or Pinks. Hardy biennials that bloom the first season, remaining green all winter and blooming the next year also if lightly protected. Old plants flower the earliest, but as young ones give the largest, finest flowers, sowings are made every year. Seed can be sown under glass in the spring, or in an open, sheltered bed. The seedlings are easily transplanted. Average height, 1 foot. Mixed, all colors ...........1/4 oz. 25c.

DAHLIA. A popular late summer and autumn flowering plant. The seed may be planted early in the hotbed and the plants set out in May after all danger of frost is over. By sowing the seed early the plants may be made to bloom the first year.

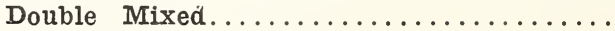

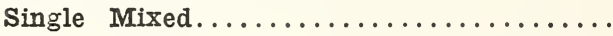

DIDIsCUS. (Blue Lace Flower) An attractive annual blooming from July until frost. The flowers are pale lavender and are invaluable for cutting. Height $1 \frac{1}{2} \mathrm{ft} . . . \ldots \ldots \ldots \ldots$.

FEVERFEW. Free-flowering annuals for bed, borders and pot culture.

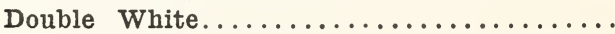
Golden Feather. Very popular for edgings. 1 foot.........................

GRASSES (Ormamental.) Ornamental grasses serve the double purpose of rendering the mixed flower bed or border attractive during the summer and for the use of the spikes or panicles in a dried state in winter bouquets.

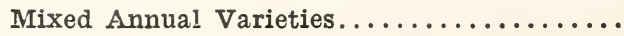


Per Pkt.

gschscholtzIA (California Poppy.) The foliage is finely cut and has a blush tinge, delicate and very attractive. The large, handsome flowers, two inches or more in diameter, are produced in great profusion all summer. Seeds can be sown where the plants are to bloom. Hardy annual; height, 1 foot.

SCARIET BEAUTY. This is one of the brightest colors in Eschscholtzias, it being a deep scarlet and as the plants are very erect, it has the appearance when in bloom of a vivid

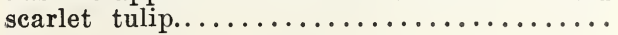

Californica. Deep yellow, orange center. .....................1/2 oz. $25 \mathrm{c}$. Mandarin. Deep Orange........1/2 oz. 25c. Carmine King. Carmine-Rose ....1/2 oz. 30c. Grandiflora Mixed Colors .......1/4 oz. 25c.

GAILIARDIA. Very showy plants with brilliant flowers. Hardy annuals, 2 feet high.

Double Mixed. Annual ........1/4 oz. 25c.

GODETIA. Beautiful garden plants, having large, delicately shaded blossoms. Easily cultivated in garden soil. Hardy annual; about 1 foot high

Finest Mixed ............1/4 oz. 25c.

GOURDS. Ornamental, rapid-growing, trailing annuals, with curiously-shaped, highly-colored fruits. Cultivate the same as melons or squashes; 10 to 20 feet.

Mixed Varieties ............1/2 oz. 25c.

GYPSOPHILIA (Baby's Breath). Free-flowering, elegant plants, succeeding in any garden soil.

Elegans grandiflora alba. A hardy annual, pure white flowers ............1/4 oz. 25c

HELICHRYSUM. (Straw Flower.) Everlasting flowers, large and full. Cut before the flowers fully expand. Hardy annual. 2 feet. Double Mixed ............. 1/4 oz. 25c.

EIELIOTROPE. This class of plants is one of the finest for cutting, as the delicious fragrance of all the varieties is very durable. For the same reason they make excellent house plants. Seed sown early in the spring in the house will make fine plants for summer bedding.

Queen Marguerite. Bears immense clusters of large deep dark-blue flowers. Very fragrant Finest Mixed.............. I/8 oz. 35c.

HOLIYHOCK. Hardy annuals, blooming the first season.

Single Mixed..............1/4 oz. 35c. .10

Double Mixed...............1/4 oz. 50c. .10
HUMULUS JAPONICUS (Japanese Hop.) FastPer Pkt. growing, annual climber. 12 feet..1/4 oz. $35 \mathrm{c}$.

HYACINTH BEAN. Tender, climbing annual. Grows rapidly and is valuable for covering a trellis. The shining purple seed pods are very ornamental.

Finest Mixed ............... oz. 40c.

KOCHIA CHILDSII (Summer Cypress.) A splendid ornamental annual plant, forming dense oval bushes 2 to $2 \frac{1}{2}$ feet high, of small, feathery, light green foliage. As summer advances, this changes to a carmine hue and finally to a fiery red. A very attractive plant. ..................... 1/4 oz. 35c.

IARISPUR. (Delphinium.) Very ornamental plants, producing, in great variety of form and colors, some of the most beautiful flowers in cultivation.

Dwarf Rocket. 1 foot in height.

Mixed Colors ............1/t oz. 30c. Stock-Flowered. Double, branching; fine for cutting. 2 feet. Mixed colors...1/4 oz. 30c. Double Stock Flowered Tall "Exquisite." An excellent variety for eutting or garden decoration, growing $2 \frac{1}{2}$ to 3 feet. The color is a beautiful soft pink. Hardy annual.

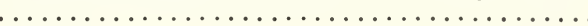

IAVATERA (Mallow.) Beautiful hardy annuals covered the entire summer with saucer-shaped flowers. The seed may be sown where they are to bloom. Height 2 to 3 feet.

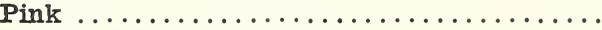

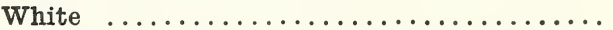

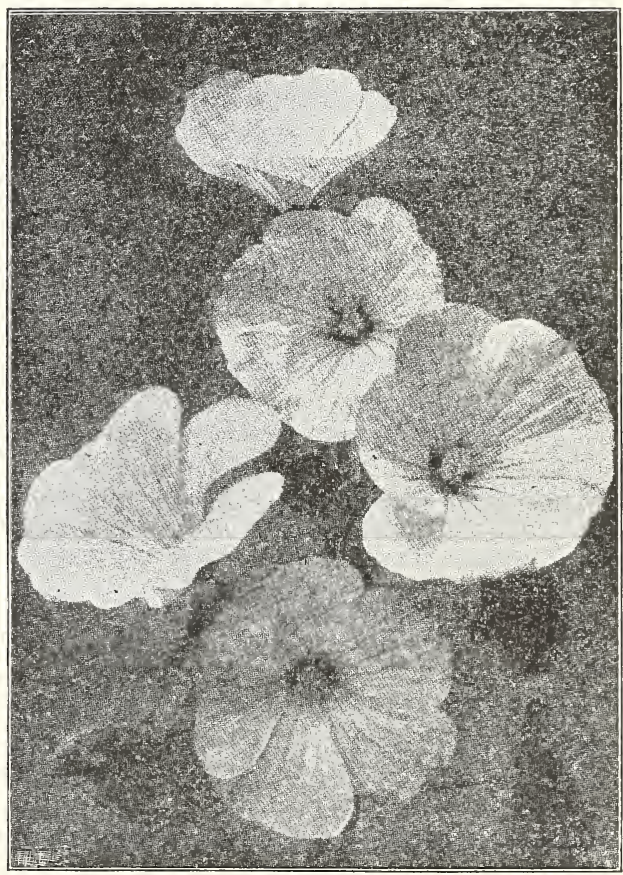

LAVATERA 
Per Pkt.

IINUM Grandiflorum Rubrum (Scarlet Flax.) A beautiful and effective plant of slender and delicate growth, having a profusion of bright flowers. Hardy annual; about 11/2 feet high.

IOBELIA. The dwarf varieties are very useful for edging, and the trailing varieties for hanging baskets and window-boxes.

Erinus gracilis. Blue trailing..... T/8 oz. 40 c. Crystal Palace Compacta. 6 inches.

Dark blue bedding variety....... 1/8 oz. 50c.

LOVE-IN-A-MIST. A hardy annual, 1 foot high, with finely cut foliage. Oddly shaped blossoms in blue and white, and curious seed pods. Of easy culture.

Mixed. Blue and white shades....1/2 oz. $25 \mathrm{c}$.

LOVE LIES BLEEDING. Light yellowish green foliage; long, drooping, crimson flower spikes. Plant 3 to 4 feet high. Hardy annual......

IUPINS. Showy plants, with long spikes of various colored pea-shaped flowers; very desirable for mixed borders.

Fine Mixed ...............1/2 oz. 30c.

MALOPE. Free-blooming, hardy annuals suitable for mixed borders and fine for cutting. Height 3 feet.

Grandiflora Mixed ..........1/2 oz. 25c.

MARIGOLD (Tagetes.) A hardy annual plant, in dwarf and tall varieties, growing from 6 inches to 2 feet high. Foliage bright green, deeply cut and graceful. The flowers are various shades of yellow and brown. The tall varieties are very valuable for large bedding or background work, and the dwarf varieties for borders. Seeds can be sown in a cold frame and the plants transplanted late in the spring or in the open border.

\section{DOUBLE AFRICAN VARIETIES}

Orange Prince. A double variety with quilled petals; flowers showy, bloom very early .................. Lemon Queen. Large, lemon-colored flowers

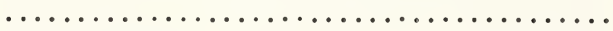
Mixed Colors ..............1/4 oz. 20c.

\section{FRENCH VARIETIES}

Tall Double Mixed ...........1/4 oz. 20c. Dwarf Double Mixed .........1/4 oz. 20c.

MIGNONETTE (Reseda.) A hardy annual, growing 6 to 12 inches high and bearing pyra. midal-shaped flower spikes, which are exceedingly fragrant. Grows easily from boxes or sown out in the garden and thinned to 4 or 6 inches. Valuable for potting, for bedding or for border.

Large Flowered. Very sweet ....1/2 oz. 20c. .10

Goliath Red. A giant red-flowered variety with rich green foliage, especially suited for house culture. ............... 1/4 oz. 50c. Goliath White. This splendid white variety has the same characteristics of the red sort. ........................ 1/4 oz. 50c.

.10

.10

.10

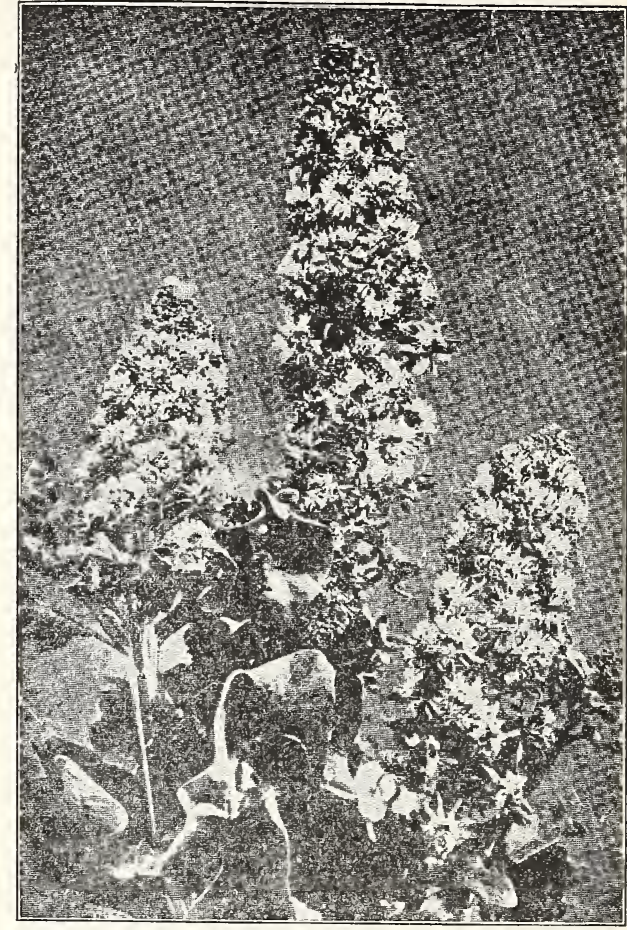

MIGNONETTE

Per Pkt.

MARVEL OF PERU. The flowers of this oldfashioned favorite open about four o'elock in the afternoon and fade the next morning. 2 feet high, with bright foliage and fragrant flowers of desirable colors. Seed should be planted in the open ground where plants are desired.

Mixed Colors ............. 1/2 oz. 20c.

MOONFLOWER. A beautiful vine which grows very rapidly, attaining a height of 50 feet in a season, producing flowers 3 to 4 inches across. Blossoms evenings and cloudy days. Soak the seeds in warm water 24 hours before planting.

Grandiflora Alba. Large white flowers

....................1/2 oz. 25c. Giant Pink... Soft lilac-pink flowers.

.....................1/2 oz. 25c.

MOURNING BRIDE (Scabiosa.) A very showy free-flowering plant, producing a great profusion of beautiful and richly-colored double flowers. Beautiful in the garden and excellent for bouquets. 12 to 18 inches high. Annual.

Mixed Colors ..............1/4 oz. 25c.

MIMULUS (Monkey Flower.) Handsome flowers of easy cultivation. Perennial in the greenhouse, annual in the open air.

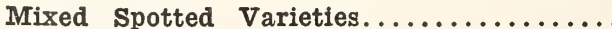

MUSK PLANT. Fragrant plant, with small yellow blossoms, spotted lightly with brown... 


\section{NASTURTIUM}

A popular flower which is in constant bloom throughout the season, making a better display than almost any other plant. New colors are being developed, and in our list will be found all the best varieties that have been introduced.

Nasturtiums are of the easiest culture and require very little care after the seed is sown, merely weeding and the seed-balls pickerl off. If these are permitted to mature the beauty of the plant is soon lost. Plant the seed one inch deep in moderately good soil. The tall sorts are specially adapted for covering unsightly fences or trailing over rocks and rough ground. Hardy annual.

\section{Dwarf Varieties}

Of dwarf, compact growth; bloom in two months from sowing and most profusely the whole season. Height 1 foot.

Aurora. Light reddish-orange, veined with carmine ................... .05 .15 .40

Beauty. Scarlet and yellow ........... $.05 \quad .15 \quad .40$

Bronze, Golden Brown............ . . . . . . .40

Crystal Palace Gem. Sulphur-yellow spotted with carmine ............

Empress of India. A splendid variety, with dark leaves and crimson

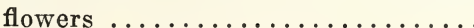

Golden King. Golden yellow........

Golden Midnight. The foliage is a light yellowish-green, while the flowers are of such a dark maroon as to seem almost black ............

King of Tom Thumbs. Dark foliage, scarlet flowers ................

King Theodore. Intensely dark crimson

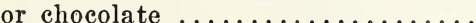

Pearl. Creamy white

Queen of Tom Thumbs. Variegated foliage, bright erimson flowers....

Vesuvius. Salmon pink, dark foliage..

Scarlet. Brilliant scarlet flowers..... $.05 \quad .15 \quad .40$

Collection of six varieties for $20 \mathrm{c}$.

\section{DWARF MIXED NASTURTIUMS}

A., S. \& I. Extra Choice Mixture. Our own mixture from a selection of named varieties and colors. Nothing finer. Pkt. .05c., 0z. 15c., 1/4 lb. $.40 \mathrm{c}$. 1 lb. $\$ 1.25$.

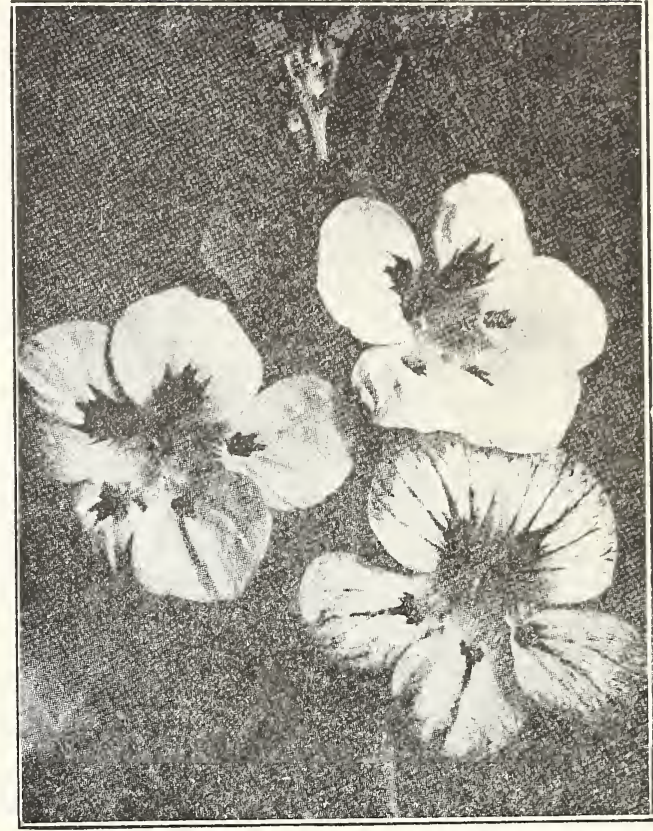

NASTURTIUM

\section{Tall or Climbing Varieties}

Height, 10 to 12 feet.

Pkt. Oz. $1 / 4 \mathrm{lb}$.

Coccineum. Scarlet................ $.05 \quad .15 \quad .40$

Dark Crimson........................ .05 $\quad .15 \quad .40$

Dunnett's Orange...Deep Orange..... $.05 \quad .15 \quad .40$

Hemispliaericum. Orange-salmon and scarlet ........................ . . . .40

King Theodore. Dark red, extra fine.. $.05 \quad .15 \quad .40$

Pearl. Creamy white................. $.55 \quad .15 \quad .40$

Prince Henry. Light yellow, marbled with scarlet.................... $.55 \quad .15 \quad .40$

Schillingi. Bright yellow, blotehed with maroon....................... $.55 \quad .40$

Vesuvius. Brilliant salmon-rose, darkleaved .................... .05 .15 .40

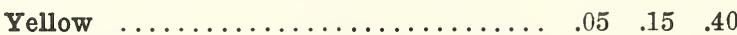

Collection of six varieties for $20 \mathrm{c}$.

\section{TALI MIXED NASTURTIUMS}

A., S. \& I. Extra Choice Mixture. Our own selection. Pkt. .05c., oz. .15c., 1/4 lb. .40c., 1 lb. \$1.25.

Per Pkt.

NEIMESIA STRIMOSA SULTONI. Free blooming plants for pot culture and open border. Sow the seed in March under glass or sow out of doors in May. Hardy annual. 1 foot. Blue, lilac, and white flowers............

NICOTIANA. Showy plants with slender, tall, flowering stems and fragrant flowers; halfhardy annuals. About 3 feet high.

Affinis. White and very fragrant......... .10

Mixed Hybrids. All colors............. .10 


\section{PANSY}

Pansies thrive best in a moist, shady location and in rich, loamy soil. Seed should be sown in the autumn for early spring blossoms. If sown in the spring, get it in as early as possible, so as to secure flowers during the early rains. Seed sown in a cool place in May or June, and well watered until up, will produce fall-flowering plants. To have good flowers, the plants must be vigorous and make a rapid growth; use manure liberally.

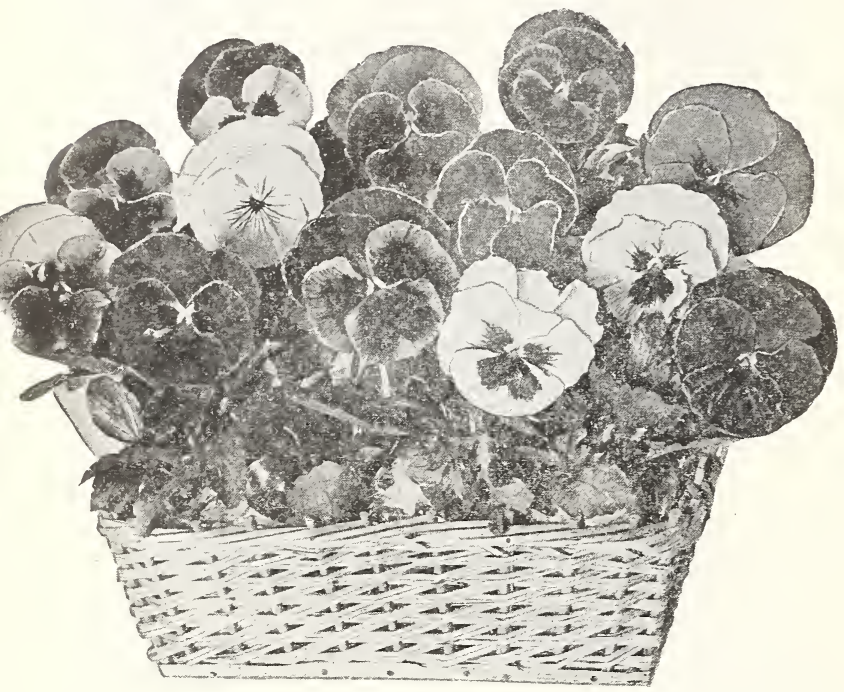

Per Pkt.

Mastodon Miracle Mixed (new.) A super mixture containing the finest types of pansies including ruffled flowers, and many new sunburst pansies, smoky rims, henna shades, with fine

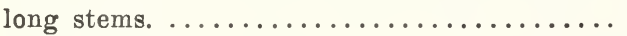

Greenhouse Special Mixed. ......1/8 oz. $\$ 2.00$

“A., S. \& L.' Special mixed.....1/8 oz. $\$ 1.00$

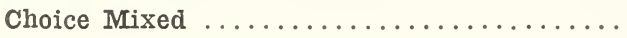

PASSION FLOWER (Passiflora.) A half-hardy perennial climber, bearing attractive blue fringed flowers. Height 10 to 15 feet.......

PHLOX DRUMMONDII. Grandiflora. One of the most satisfactory bedding plants. A hardy annual growing about one foot high, and bearing beautiful and brilliantly colored flowers.

Isabellina. Yellow ............... .10

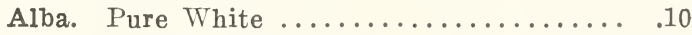

Alba Occulata. Dark Purple, white eye.... .10

Brilliant. Bright Scarlet...............10

Finest Mixed. Best large-flowered varieties ......................1/4 oz. 50c. .10

\section{POPPY (Papaver)}

The seed should be sown as early in the spring as possible where they are to remain, as they do not stand transplanting. Thin 6 to 10 inches apart. If left thick the plant will be weak and the blossoms inferior.

\section{SHIRLEY VARIETIES}

Per Pkt.

“'A., S. \& I.', Single Mixed. The most beautiful type of poppies, having soft foliage and an immense variety of single blossoms in white, pink, lavender, purple, shades of red and scarlet; the best and most showy of all single poppies.................. oz. 50c.

“American Legion." This new single Shirley is a dazzling orange scarlet of enormous size, borne on long stout stems. The plants are of very erect robust growth........... 75 c.

Salmon Shades, Double ........1/4 oz. 25c. .10 Pink Shades, Double ..........1/4 oz. 25c. .10

\section{CARNATION VARIETY}

Double Mixed .............1/2 oz. 25c. .10

\section{SNOWDROP}

Pure White ............1/2 oz. 20c. .10

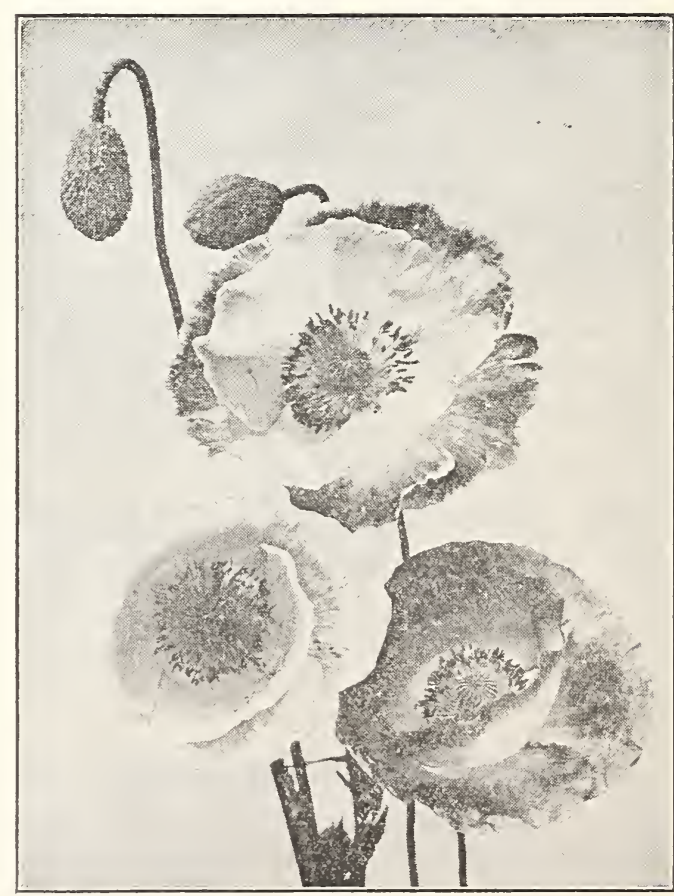

SHIRLEY POPPY 


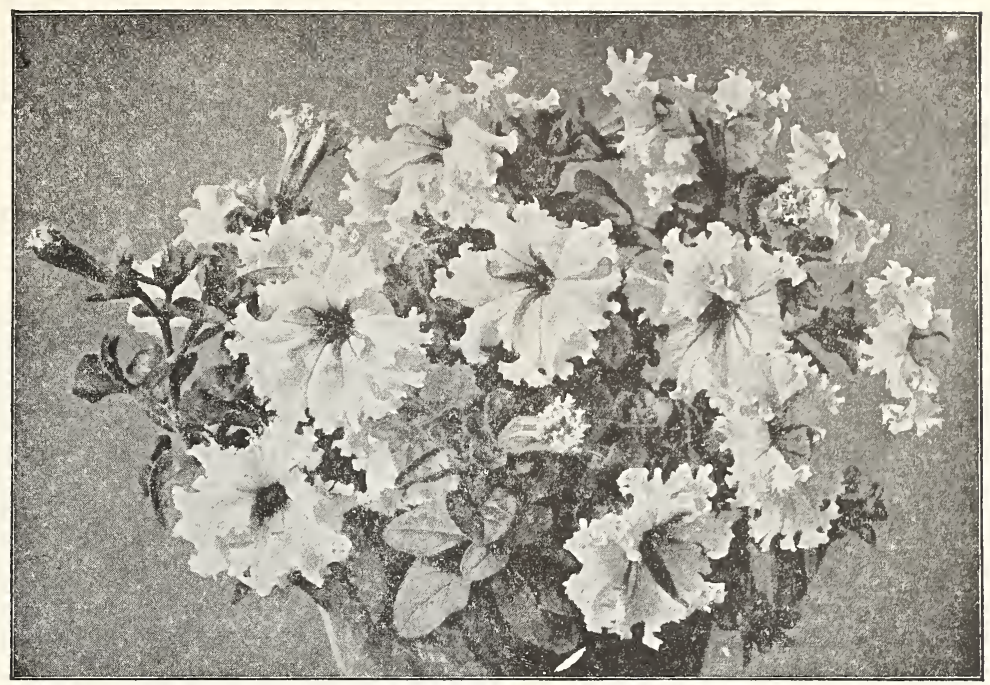

FRINGED PETUNIA

PETUNIA. Free-flowering and easily cultivated; well-known favorites. They thrive in almost any soil and produce a brilliant array of color throughout the season. The seed will germinate with little difficulty if a reasonable amount of care is used in sowing. Be sure that the soil is well pulverized; then sow the seeds on the surface, pressing them into the soil by using a small smooth board, and cover very lightly with fine soil.

Per Pkt.

Large-Flowered Single, Fringed. Choice mixed ....................... \$0.25

Large-Flowered Double. Choice mixed .... .50

Giants of California. Flowers very large, and deeply fringed. A variety of colors........ Ruffled Giants. Flowers of enormous size, with ruffled edges and brilliant colors...... Rosy Morm. A bright rosy pink with white throat ................... 1/4 oz. $\$ 1.00$ Howard's Star. A beautiful free-flowering strain, color a rich, dark crimson, with five-

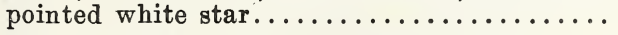
Choice Mixed. Striped and blotched.

...................1/8 oz. 25c.,

PORTULACA. The plants are of low growth and spreading habit. The flowers of the double varieties are like small roses, and make a particularly brilliant show. Sow seed in the open ground as soon as the weather is warm, or in a hotbed earlier. The plants can be transplanted when in full flower. Annual.

Double Mixed Colors ..........1/8 oz. 50c. Single Mixed Colors .......... 1/8 oz. 20c.

PRIMUIA (Chinese Primrose.) A beautiful flowering plant for winter decoration in the home or conservatory.

Sow the seed in well-drained shallow pans, from April to the last of July, to insure flowering the following winter.

Giant Fringed. Mixed Colors............

RHODANTHE. Fine for garden. Comes into flower early and continues a long time. One of the best everlasting for bouquets.

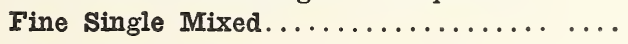

RICINUS (Castor Oil Bean.) A half-hardy annual, growing from 6 to 15 feet high and bearing large, green, deep purple and brown leaves, and bright orange and scarlet flowers. Of the easiest culture. Fine for lawns, massing or center plants for beds.

Per Pkt.

Zanzibarensis Mixed. A very large-leaved variety, light and dark green and bronze foliage;

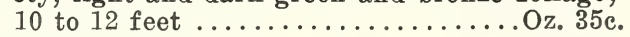

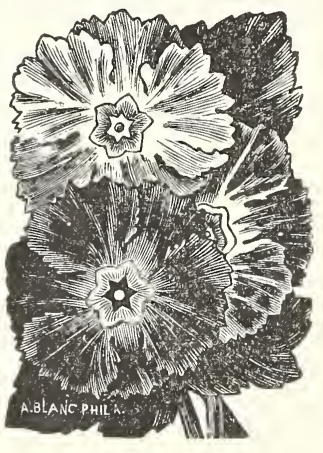

PRIMULA

SATPIGLOSSIS. Very showy bedding or border plants with richly-colored flowers, which are purple, scarlet, crimson, yellow, buff, blue or almost black, beautifully marbled and pencilled. Hardy annual, 2 feet.

Emperor. Finest Mixed. Very large flowers. .......................1/8 oz. 50..

SCHIZANTHUS. Hardy annuals, growing 11/2 to 2 feet high, and covered with bright, showy, butterfly-like blossoms.

Choice Mixed Large Flowering ...........

SIMILAX. A graceful climber with small, dark

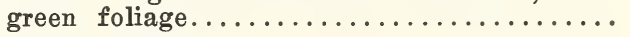




\section{SWEET PEAS}

The popularity of Sweet Peas is demonstrated by the many and beautiful varieties that are introduced each year. Our list includes all the best up-to-date varieties.

Sow as early as the ground can be prepared in a deep, rich, moist soil, in drills 6 inches deep, covering about 2 inehes deep. As the vines grow, fill up the trenches with soil and thin out to about 4 or 5 inches apart. A popular plan at the present time is to sow in double rows with a trellis or a row of brush between.

One-quarter of a pound of seed will sow fifty feet.

\section{Giant Spencer Varieties}

The Spencers have very large waved flowers which are produced abundantly on long, strong stems, and are most desirable for cutting.

Alexander Malcolm. Very bright scarlet cerise.

Apple Blossom Spencer. Standard bright rose, wings primrose with a flush of rose.

Astra Ohn. The best lavender, very large and wavy.

Aurora Spencer. White, with stripes and flakes of orange-pink.

Barbara. Bright salmon orange with dark stems.

Contance Hinton. The largest white Spencer.

Countess Spencer. The original giant-flowered Spencer, clear pink.

Crimson King. The color is a solid, rich, deep, clear crimson throughout, becoming richer in the throat.

Dainty Spencer. White with rose-pink edges.

Daisy Bud. Soft pale rose pink.

Dobbie's Cream. The finest primrose-yellow.

Florence Nightingale. Large, pure lavender.

Geo. Herbert. A large Spencer, rose-erimson.

Hebe. A giant flower of finest form. Color bright rose pink. Flowers are beautifully waved.

Illuminator. Salmon orange overlaid with bright cerise.

Jack Cornwell, V. C. Deep blue. One of the most beautiful.

King Edward. The best pure red Spencer, very large.

King White. Large pure white.

Mrs. Hugh Dickson. Buff apricot and rose.

Mrs. Tom Jones. Deep amethyst blue, very fine form.

Pink Pearl. Clear pearly pink.

Royal Scot. Brilliant scarlet.

splendour. Rich red maroon.

Price: Any of the above

Pkt. 10c., 0z. 35c., 1/4 lb. $\$ 1.00$

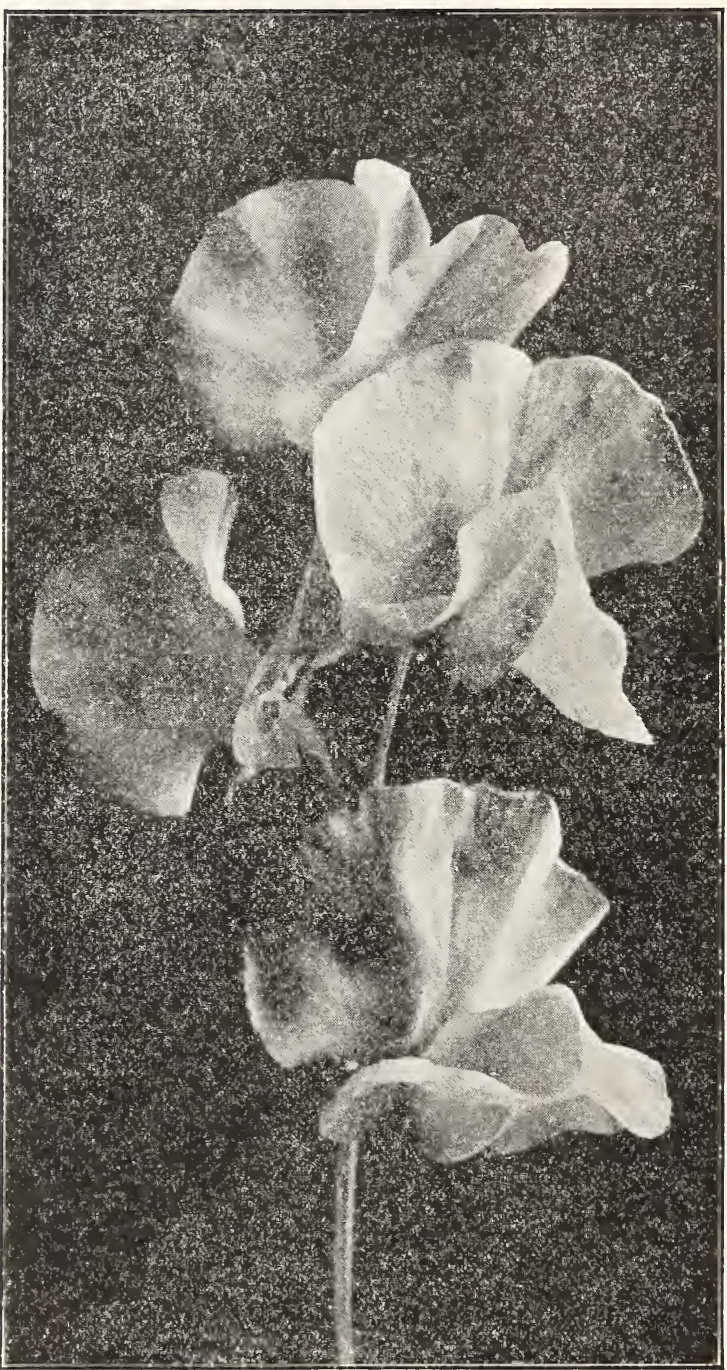

EARLY IRENE

\section{A. S. \& L. Superb Spencer Mixed}

Our own mixture of true Spencer types only. As fine a collection of Sweet Peas as can be purchased auywhere.

Pkt. 10c., oz. 20c., 1/4 lb. 60). 


\section{SWEET PEAS - Continued}

\section{Early Flowering Spencer Sweet Peas}

This new type is receiving great attention at the hands of the leading hybridizers, and already nearly all colors are represented. They are now very popular, and in great demand by commercial florists for forcing under glass for Winter and early Spring blooming, but are just as valuable for the amateur for outdoor culture coming into flower five or six weeks earlier than the regular Spencer type, and if the flowers are kept picked, continue to bloom over a period of nearly four months.

Early Aviator. A very beautiful shade of erimson.

Early Bluebird. A very attractive shade of blue growing more vigorous than any other blue.

Early Glitters. The color may best be described as a glowing poppy scarlet.

Early Harmony. Clear Lavender. This Spencer should be included in every collection.

Early Irene. This is an early Lavender Florence Nightingale, a very fine bluish lavender.

Early Snowflake. This is without doubt the finest White Sweet Pea that has been introduced. It produces flowers of the largest size on long stems.

Early Spring Maid. The finest early blush pink of robust growth, with long stems.

Early Torch. An orange scarlet that will not burn in sunlight. One of the best.

Early Yarrawa. Color bright rose-pink with lighter base.

Price: Any of the above, Pkt. 15c., oz. 60 c., $1 / 4$ lb. $\$ 1.75$.

\section{Grandiflora Sweet Peas}

These have large handsome flowers, but the petals are not waved like the Spencer varieties. Earlier than the Spencers.

“A., S. \& I." SPECIAI MIXTURF. This mixture is made up by ourselves from the best named Grandiflora and cannot fail to give satisfaction.

Oz. 10c., $1 / 4$ lb. 30c., lb. $\$ 1.00$.

\section{GRANDIFLORA MIXED SWEET PEAS IN SEPARATE SHADES}

Lavender and Blue Shades.

Purple and Maroon Shades.

White and Primrose Shades.

Pink Shades.

Red Shades.

Each of the above, oz. 10c., $1 / 4$ lb. 30c., 1 lb. $\$ 1.00$. Collection, one oz., each of the five separate shades, 40c.

\section{FREE DELIVERY}

To any address in the United States on all Flower Seeds by the packet, ounce, half-pound, and pound.

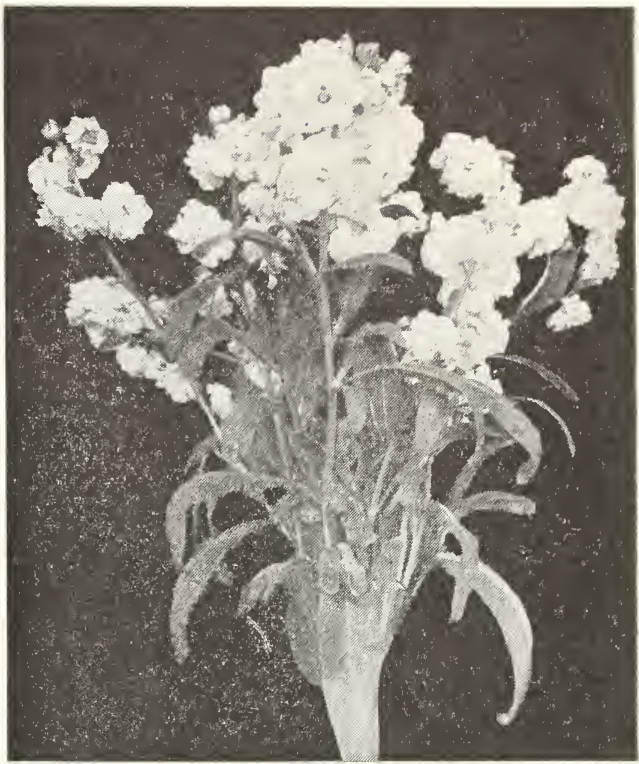

TEN WEEKS BEAUTY STOOKS

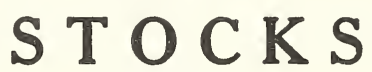

(Gilliflower)

Hardy annuals, 2 feet high, with spikes densely covered with beautiful double flowers of almost every desirable tint. Seeds may be sown in the open ground, hotbed or cold frame, but transplanting should be done when the plants are just out of the seed leaf. Make the soil deep and rich, and set the plants a foot apart.

\section{LARGE-FIOWERING TEN WEEKS BEAUTY STOCKS}

A magnificent race of recent introduction, with long trusses of extremely double flowers of delightful fragrance. For forcing in the greenhouse in Winter they are unexcelled. They are equally good when planted in the garden, coming into bloom in about 10 weeks and lasting until late in the season.

Per Pkt.

Apple Blossom ................... . . 10

Canary Yellow, (Monte Carlo)........... .10

Flesh Pink, (Beauty of Nice) ......... .10

Light Blue, (Cote d' Azure)............ .10

White, (Mont Blanc)................... .10

Choice Mixed................1/8 oz. 75c. .10

\section{IMPROVED CUT-AND-COME-AGAIN}

White (Princess Alice) ............... . . 10

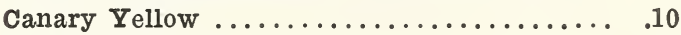

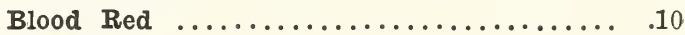

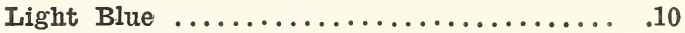

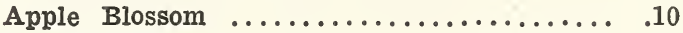

Choice Mixture .............1/8 oz. 75c. .10 
BALVIA. Sow seed early indoors or in a frame in

Per Pkt. time to get good plants to set out of doors the latter part of May. Bloom from July to frost. Set plants 1 foot apart. Half-hardy annual AMIERICA. An improved variety of dwarf, compact growth; very early and produces large spikes of brilliant scarlet flowers. 1/8 oz. $75 \mathrm{c}$.

Bonfire. Very compact, with long, erect spikes of brilliant scarlet flowers. 2 feet. ........................ oz. 60 c.

\$WEET SULTAN. Large, sweet-scented flowers Finest Mixed .................. 50.

SUNFLOWER (Helianthus.) Hardy annuals, growing from 3 to 6 feet high. Of the easiest culture and suitable for a stately row or background. Plant in light or sandy soil.

Californicus fl. pl. Splendid variety, with magnificent heads of double orange flowers.

Height 5 feet................. 35c.

Miniature. Small, single rich yellow flowers, with black center. 4 feet.......... Oz. 35̃c. Sutton's Red. Single large red flowers, shading to yellow at tips of petals.

Height 6 feet................... 35c. Mammoth Russian. Large yellow. Oz. 10c.

TEONBERGIA. (Black Eyed Susan.) Beautiful annual trailing plants for hanging basket and vases. Mixed colors. 4 feet....1/4 oz. 25 c.

VERBENA. A well-known annual for beds, and borders. Seed sown in March will bloom in June and continue until frost. Plants raised from seed are more vigorous and produce more flowers than those grown from cuttings. “A., S. \& L.”' Mammoth Mixed 1/4 oz. 50c.

WILD CUCUMBER (Echinocystis Lobata.) This is a useful climber where a rapid and vigorous growth of vine is desired. The vine is thickly covered with white, fragrant flowers. Hardy annual...................1/2 oz. $25 \mathrm{c}$.

WILD GARDEN FLOWER SEEDS. A mixture of easily grown varieties of Flower Seeds for Sowing broadcast, require very little care and produce a continual display of bloom throughout the season, and furnish an abundance of flowers for cutting. They are useful for sowing along fences and on unsightly bare spots of ground.............. Oz. 15c., 1/4 1b. 50c.

ZEA JAPONICA (Striped Japanese Maize.) Very ornamental, variegated foliage........

PREMIUMS-With an order for One Dollar's worth of Flower Seeds, in packets, you may select 25 cents' worth of Flower Seeds Extra. For $\$ 2.00$ you may have 50 cents' worth extra, and for $\$ 4.00$ you may have $\$ 1.00$ worth extra.

.10
.10
.10

\section{ZINNIA}

A hardy annual, growing from 1 to 2 feet high. One of the most brilliant and showy plants. They flower early in the summer and keep on blooming until frost.

“'A., S. \& L.', Double Choice Mixed ........

Per Pkt. .....................1/4 oz. $40 \mathrm{c}$.

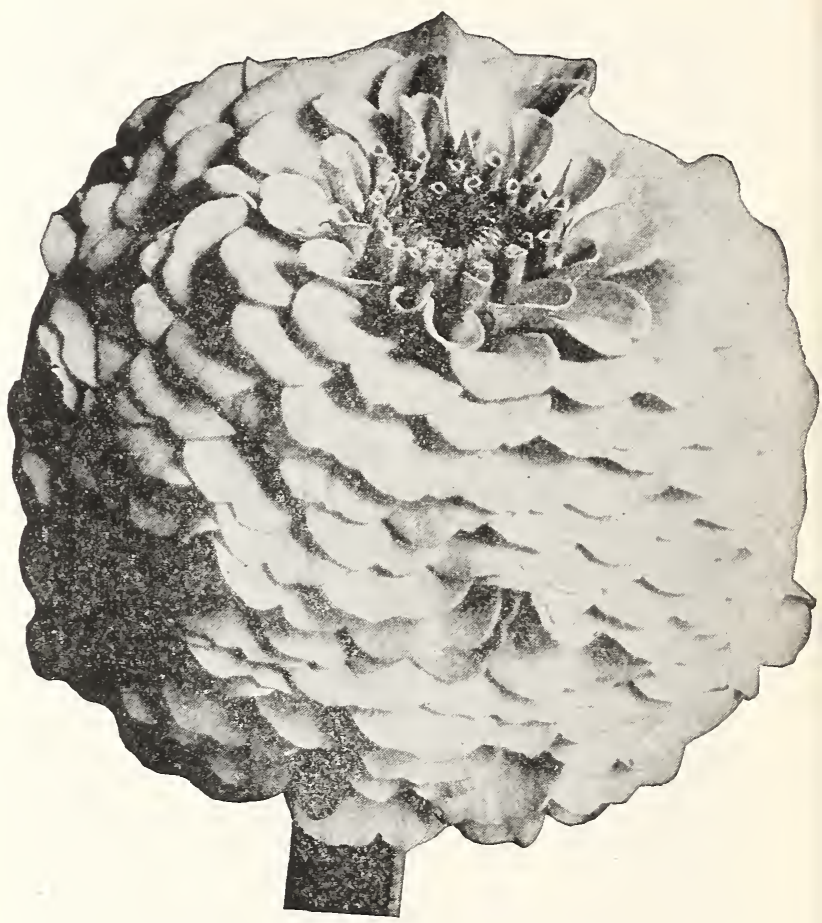

\section{GIANT DAHLIA FLOWERED ZINNIA}

A wonderful improvement in Zinnias, the flowers being as large as Dahlias. The plants of this variety are very strong and rugged, growing to a height of about three feet.

Per Pkt.

Buttercup (New). A large deep creamy yel-

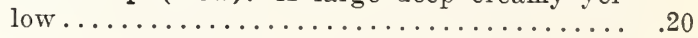

Crimson Monarch. By far the largest and best of the red shades. Flowers often eight

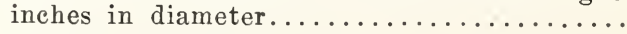

Dream. A fine deep lavender, turning to purple. A new, desirable shade in Zinnias....... Exquisite. Color light rose with center a deep

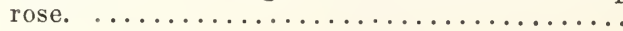

Golden State. A very rich orange yellow. Yellow in the bud, turning to an attractive

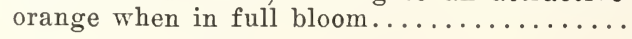
Oriole. Considered the most beautiful of its class. It is an immense orange and gold

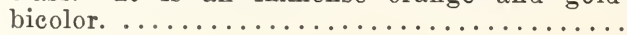

Polar Bear. A very large pure white, the best white yet seen in Zinnias. True Dahlia

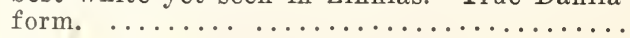

Scarlet Flame. A large, beautiful, bright scarlet, with a delightful blending of orange

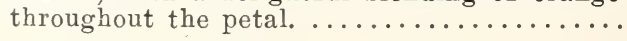
Special Mixture. ......... (3 pkts. for 50c.) 


\section{"Sterling Quality" PERENNIAL FLOWER SEEDS}

Per Pkt.

AOONITUM (Monk's Hood.) Hardy perennial, with helmet-shaped flowers; growing in any good garden soil. Thrives best when planted among shrubbery or in shady situations. 4 feet.

Nappellus. Large blue.

AIISSUM. Saxatile Compactum (Basket of Gold.) Golden yellow flowers...1/4 oz. 50c.

AMPELOPSIS VEITCHII (Boston IVy.) The best hardy vine for covering brick or stone build. ings, etc.; foliage turning to scarlet in the autumn. $1 / 2 \mathrm{oz} .25 \mathrm{c} . \ldots \ldots \ldots \ldots \ldots \ldots \ldots$

BELLIS PERENNIS (Double Daisy.) Sow the seed very early. The flowers are abundant in early spring and may be continued later by the use of water. Set about six inches apart in a cool border.

Longfellow. Large, rose-colored flowers. .... Snowball. Large, double pure white. ....... Finest Mixed..............1/8 oz. 40c. Shasta Daisy. Pure white. .............

CANTERBURY BELLS. Large bell-shaped flowers which are very effective. Succeeds best in light, rich soil. Transplant two feet apart. Height 2 to 4 feet.

Single, Fine Mixed ..........1/8 oz. 25c. Double, Fine Mixed..........1/8 oz. 25e.

Cup and Saucer.

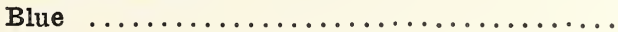

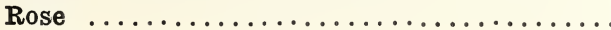

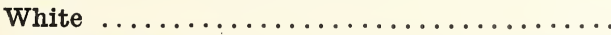

Choice Mixed .............1/8 oz. 60 e.

OOLUMBINE. (Aquilegia.) Well-known hardy perennials, bearing in great profusion, through May and June, exquisite flowers greatly varied in coloring; of easy culture, thriving best in dry soil and growing well in partial shade. 1 to 3 feet.

Single, Mixed Colors................

Double, Mixed Colors...............

\section{DELPHINIUM (Hardy Larkspur.)}

Formosum. Deep blue, 3 feet........... Double Hybrids, Finest Mixed. 3 feet......

\section{DIANTHUS (Hardy Garden Pinks.)}

Double Clove. A hardy perennial pink, very fragrant, choice colors.........1/8 oz. 30c. Plumarius (Grass Pink, or Pheasant-eye Pink.) A single hardy Pink with fringededged, fragrant flowers, mixed colors ........................1/8 oz. 30c.

EUPHORBIA VARIEGATA (Snow on the Mountain). Variegated green and white foliage.

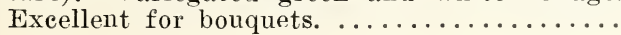

FORGET-ME-NOT. (Myosotis.) Small star-like Howers borne in clusters. The plant is of easy culture and blooms the first year if seed is sown early. 4 to 9 inches.

Indigo Blue. Large, dark blue flowers.

$\ldots \ldots \ldots \ldots \ldots \ldots \ldots \ldots \ldots \ldots \ldots \ldots$ oz. $25 \mathrm{c}$.

Victoria. Large flowers, bright azure blue; dwarf habit; fine for borders......1/8 oz. 35e. Fine Mixed..............1/8 oz. 25c

FOXGLOVE (Digitalis.) The Foxgloves are highly ornamental plants. They are fine for the mixed border or planted singly in half. shady places near a walk or drive. The spikes of flowers are often two feet in length, containing scores of the pretty-spotted, thimbleshaped flowers. Perfectly hardy. Sow seed in spring in the garden and transplant as desired.

Mixed varieties.............1/4 oz. 25 c.

FRENCH HONEYSUCKLE (Hedysarum.) Very handsome, free-flowering plants; well adapted for borders or rock-work. 4 feet.

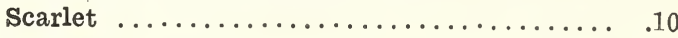

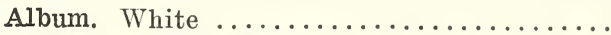

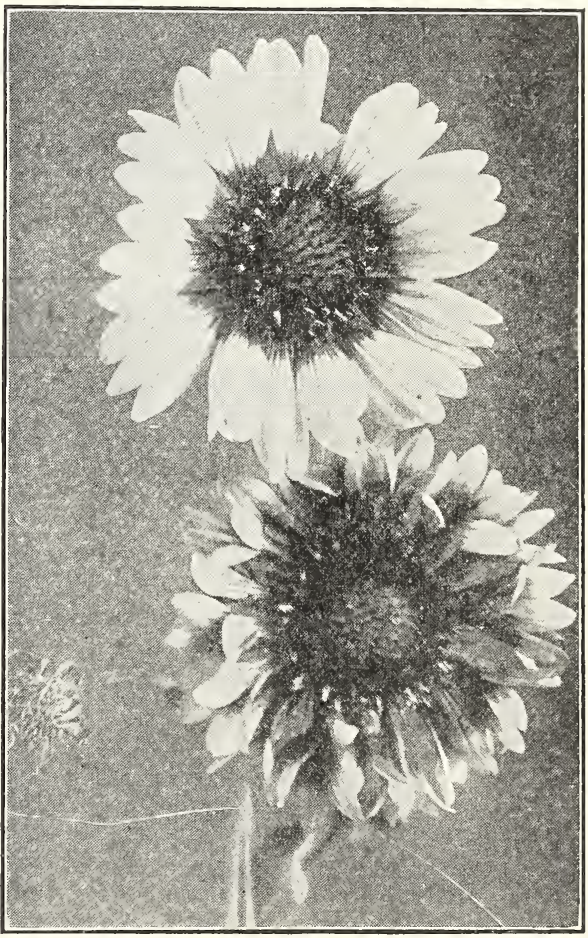

GAILLARDIA

GAILLARDIA. Showy and hardy perennials, Flowering from July to October, $2 \mathrm{ft}$.

Grandiflora Hybrida. Finest Mixed. 


\section{PERENNIAL FLOWER SEEDS-Continued}

Per Pkt.

GYPSOPHILA. (Baby's Breath.) Free-flowering, plants, succeeding in any garden soil. Fine for bouquets.

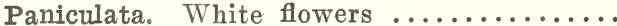
.10

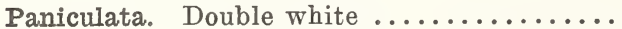

HOLLYHOCK. Plants of upright, stately growth, 5 to 8 feet high. The double varieties are the most desirable. Very effective when planted in long rows with a background of shrubbery.

Finest Mixed. Single..........1/2 oz. 25c. .10

Chater's Double Red............1/8 oz. 30c. .10

Chater's Double Pink............1/8 oz. 30c. .10

Chater's Double Yellow..........1/8 oz. 30c. .10

Chater's Double White..........1/8 oz.30c. .10

Chater's Double Maroon..........1/8 oz.30c. .10

Chater's Double Salmon..........1/8 oz.30c. .10

Chater's Double Mixed............1/8 oz. 30c. .10

HONESTY (Satin Flower.) The flat, silvery seed pods are used for winter decoration. Very handsome, free-flowering. Hardy biennial. 2

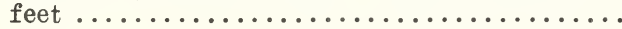

\section{IBERIS (Perennial Candytuft.)}

Sempervirens. Pure white; excellent for cemeteries, rockeries, etc.; 1 foot...........

Kudzu Vine or Jack-and-the-Bean Stalk. A fast growing hardy perennial vine, growing 8 to 10 feet the first year from seed. The foliage is large; it bears clusters of pea-shaped flowers...................1/4 oz. $25 \mathrm{c}$.

LAVENDULA vera. (Sweet Lavender) grown chiefly for lasting fragrance of its flowers. .......................1/4 oz. 25c.

\section{LINUM (Flax)}

Perenne. Bright blue flowers, hardy. $2 \mathrm{ft}$.

LUPINUS (Lupin.) Beautiful hardy plants for borders, beds and for cutting, $3 \mathrm{ft}$.

Polyphyllus Blue.....................10

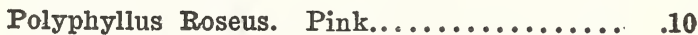

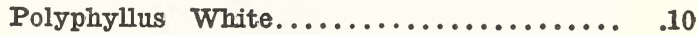

Polyphyllus Mixed ................. .10

PHLOX (Decussata.) Hardy plants producing large heads of showy flowers, $3 \mathrm{ft}$.

Mixed Colors

\section{POPPY (Papaver.)}

Orientale. One of the most striking and showy of the garden perennials; flowers large brilliant crimson with a black bloteh on each petal.....................1/8 oz. 25c. Iceland. Brilliant colors. Blooms first year from seed. ................1/8 oz. 25c.

POLYANTHUS (Primula Elatior.) Early spring free-flowering plants, fine for either pot or outdoor culture; 9 inches.

Choice Mixed
PYRETHRUM HYBRIDUM (Painted Daisy). Hardy perennial, bearing large Daisy-like flowers, ranging in color from white to deep red, with bright yellow centres. ...........

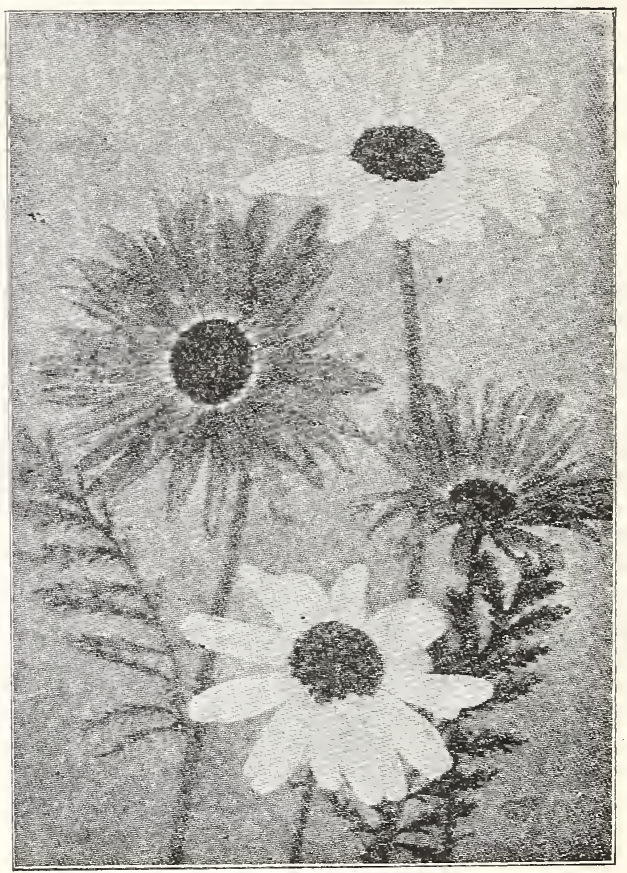

PYRETHRUM HYBRIDUM (Painted Daisy)

PHYSALIS (Chinese Lantern Plant). An ornamental plant, forming dense bushes about 2 feet high, producing freely its bright orangescarlet lantern-like fruits, which can be cut and dried for winter bouquets. ............

RUDBECKIA (Cone-Flower.) Robust-growing plants, very popular for border decoration. Newmanii. golden yellow with black center.

STATICE (Sea Lavender). Beautiful hardy perennial, free flowering and of easy culture in poor soils and dry situations; very showy in beds or borders, and remain a long time in bloom; when dried can be used in winter bouquets.

Choice Mixed

SWEET WILIIAM. An old-fashioned plant, producing large heads of beautifully colored, sweet-scented flowers. It is hardy and easily grown. $1 \frac{1}{2}$ feet.

Holborn Glory. Large flowers of the most beautiful shades............1/4 oz. 25c. Pink Beauty. Rose pink........1/4 oz. 25c. Double Varieties. Mixed........1/4 oz. 30c. Finest Single Mixed..........1/4 oz. 30c.

SWEET ROCKET. Very fragrant, growing freely in ordinary soils, $2 \mathrm{ft}$.

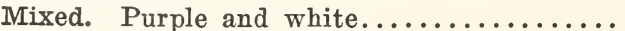

VIOLET. Fragrant, spring-blooming plants.

The Czar. Large dark blue............. 


\section{GLADIOLUS BULBS}

Gladioli are, withont doubt, the most attractive and useful of all summer-flowering bulbs, and, as a cut flower through the summer and autumn months, hold a place that cannot be taken by any other flower. They will grow in any good garden soil. Plant 6 inches apart and 4 to 6 inches deep.

After careful consideration we have decided not to list the named varieties of gladioli as we found that the greater part of our customers were interested only in a good mixture. Therefore, we offer a very fine mixture of first size bulbs containing a great variety of beautiful colors. Doz., 50c.; 100, \$3.00.

\section{CHINESE CINNAMON VINES}

\section{(Dioscorea Batatas)}

CINNAMON VINES are the most desirable, easiest grown climbers. They are perfectly hardy, thriving on all soils, in sun or shade. They will run thirty feet or more, and will quickly surround your windows and cover your porches, walks, etc., with a mass of vines covered with pretty, heart-shaped leaves and a profusion of delicate, sweet scented flowers, which perfume the air for a long distance. 10c. each, $\$ 1.00$ per doz., $\$ 6.00$ per 100 postpaid.

\section{PLANT DEPARTMENT}

PLANTS BY EXPRESS. We use great care in the packing of plants to be sent by express, but cannot bo responsible for delays or conditions when recelved by the purchaser. No plants sent C. 0 . D. Shipped bJ axpress only, except where noted.

\section{Vegetable Plants}

\section{WASHINGTON ASPARAGUS ROOTS}

This new high yielding pedigreed rust resistant Asparagus is the result of 14 years of careful scientific breeding by the Bureau of Plant Industry. The shoots are very large on the average and the high branching habit of this strain makes it possible to cut unbranched shoots with good tight buds as much as two feet long. The branches of the mature shoots after they grow up are much less spreading than those of ordinary asparagus.

We offer strong two year old Roots grown from selected seed.

Price: $\$ 2.00$ per 100 roots, postpaid $\$ 2.25$.

\section{CABBAGE PIANTS}

Early Variety

Doz. 100

Copenhagen Market ............\$.25

Late Variety

Danish Ball Head ................20

\section{CAULIFIOWER PLANTS}

Snowball (Early Variety) .........\$0.25

Danish Giant (Late Variety) ......... .25

\section{CELERY PIANTS}

$100 \quad 1000$

Golden Self-Blanching (Early) ....... \$1.50 \$10.00

Boston Market (Late) ............ $1.50 \quad 10.00$

\section{PEPPER}

doz. 100

Large Bell .................. \$0.25 \$1.50

Pimento .....................25 1.50

Rhubarb Roots. Each, 15c... $1.50 \quad 10.00$

\section{TOMATO PLANTS}

We have been especially successful the past years with our Box Grown tomato plants. Our grower has always given us sturdy, hardy plants and we have taken particular pride in offering them to our customers.

\section{Varieties}

John Baer, Earliana, Burbank, Early $\$ 1.50$ Detroit, Abbott's Early Red, Dwarf Stone,

1.50 Bonny Best, Yellow Plum............. .50 doz. 


\section{DAIRY SUPPLIES}

Let us know your requirements, we will give them prompt attention!

Agents for Louden Barn Equipment, Sharples Separators \& Milkers - Boilers, Bottle Washers, Bottle Cases, Sterilizers, etc., etc.

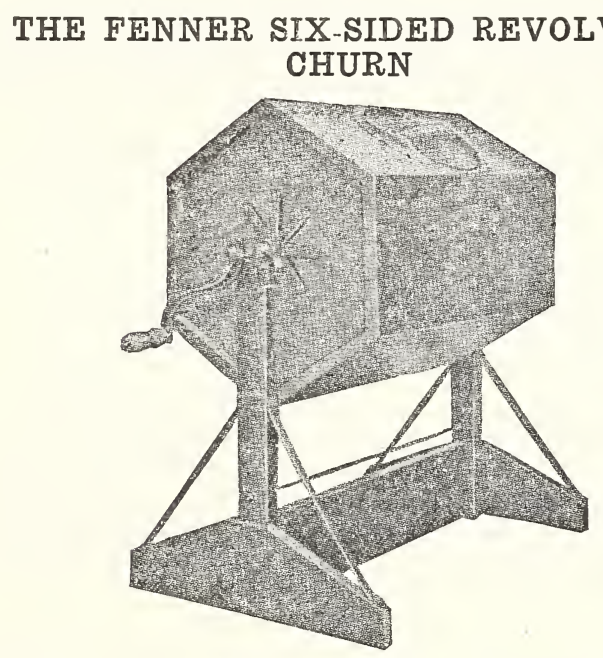

IT is the most practical, efficient, and economical churn on the market.

IT CHURNS, WASHES, SALTS, and WORKS the butter in the churn.

IT does not break the walls of the butter-fat globules.

IT is a time and labor saver.

IT takes very little power to operate.

IT is very easily cleaned because of its simplicity of construction.

IT is so built that it cannot dry out and fall to pieces.

IT is especially adapted to warm climates.

IT will last many years if properly cared for.

"Try it. You will use no other.'

Send for Catalog and prices!

\section{PARCHIMENT BUTTER PAPER}

For wrapping and covering butter, for layers and caps on top of tubs, jars, tumblers, etc.

Prices $\quad$ Box of
1000

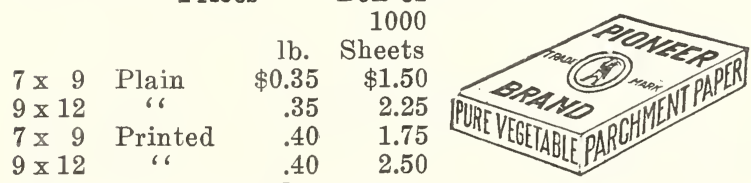

Prices do not include postage.

\section{FOLDING PARAFFINED BUTTER BOXES}

1 Pound Size (2 Pieces), Price \$ 1.50 per 100.

$$
\text { 66 66 } 12.50 \text { per } 1000 \text {. }
$$

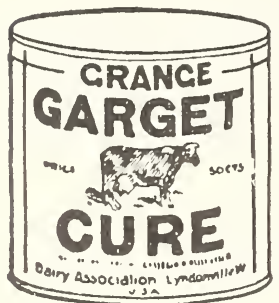

\section{GRANGE GARGET CURE}

Cures garget without in any way injuring the cow or lessening the flow of milk.

Price, 65c. per can

71c. postpaid

\section{BLANCHARD BUTTER MOULDS}

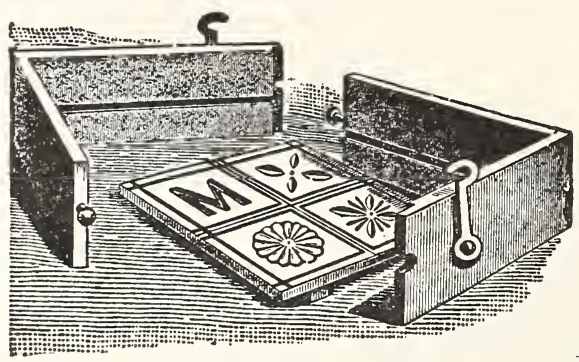

Prices

1/2 Pound, (2-1/4 lb.) Prints,

1 Pound, (4-1/4 lb.) Prints,

2 Pound, (8-1/4 lb.) Prints,

Initial Engraved, 25 cents extra for each cake.

Parcel Post $\$ 0.75 \$ 0.80$

$.85 \quad .91$

$1.15 \quad 1.21$

\section{MILK FEVER OUTFIT}

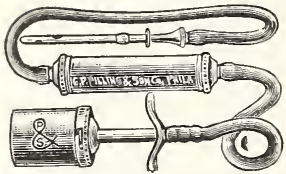

This treatment recommended by the Bureau of Animal Industry, United States Government, Department of Agriculture.

Price $\$ 3.50$ postpaid.

\section{MILKING TUBES}

For Sore and Obstructed Teats and Hard Milking Cows

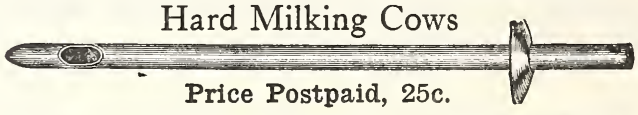

\section{KOW-KARE}

(Old name " Kow-Kure"') For Cows Only

It cures scours, removes bunches from the bag, prevents cows from losing their calves, gets barren cows with calf, and makes a strong appetite and perfect digestion that produces a larger flow of richer milk.

Price, 65c. and $\$ 1.25$

By parcel post 71c. and $\$ 1.33$

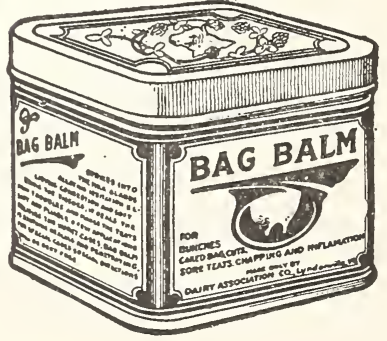

\section{BAG BALIM}

For bunches, cuts, caked bag, sore teats, chapping, and infiammation.

Price, 60c. per cán 66c. post paid 


\section{STATE AGENTS}

for

“SEALRIGHT'” BOTTLE CAPS

\section{SEALRIGHT ORDINARY OR COMIMION MILK BOTTLE CAPS}

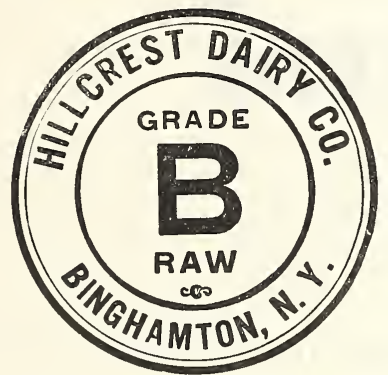

Sealright Ordinary or Common Milk Bottle Caps can be the biggest little things in your business! Because they win customers, keep them, build good will, and through their inherent ability to give better service, build added business.

\section{SEALRIGHT POURING-PULL MILK BOTTLE CAPS}

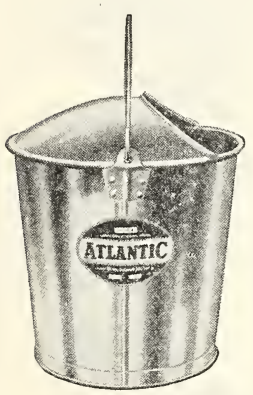

\section{Atlantic "SANITARY" \\ Dairy Pail}

Soldered Inside and Outside

12 Quart, Price, $\$ 2.25$

14 Quart, Price, $\$ 2.50$

\section{ATLANTIC EXTRA HEAVY RETINNED SEAMILESS MILK STRAINER}

(Removable Strainers)
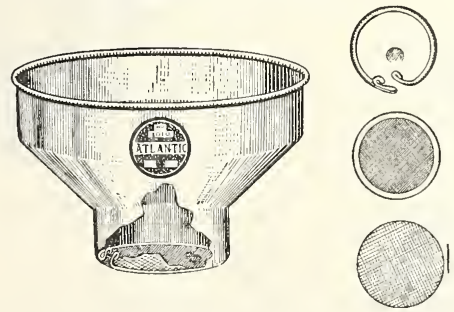

Fitted with Spring Lock, one 14-Gauge Aluminum Dise, $\frac{3}{16} "$ perforations. One Brass Strainer Cloth Dise, 80-Mesh.

No. $1010-12$-qt. $4 X$ $\$ 2.00$ each

\section{STRAINER PADS}

Carton 300 pad

\section{DAIRY BRUSHES}

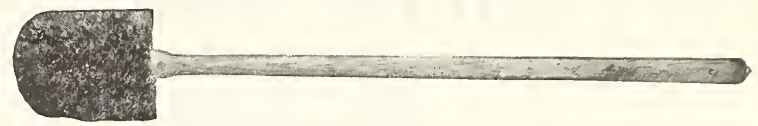

No. 89. Hand Can Brush. Grey Tampico, brush part 5 inches diameter, 5 inches long, length of handle 24 ins., length over all 29 ins. Price, \$1.25 each.

No. 123. Machine Bottle Brush. Paint Stump Bristle brush part 3 inches diameter, handle j inches long, tapered to $1 / 2$ inch diameter at end. Price 75c. each.
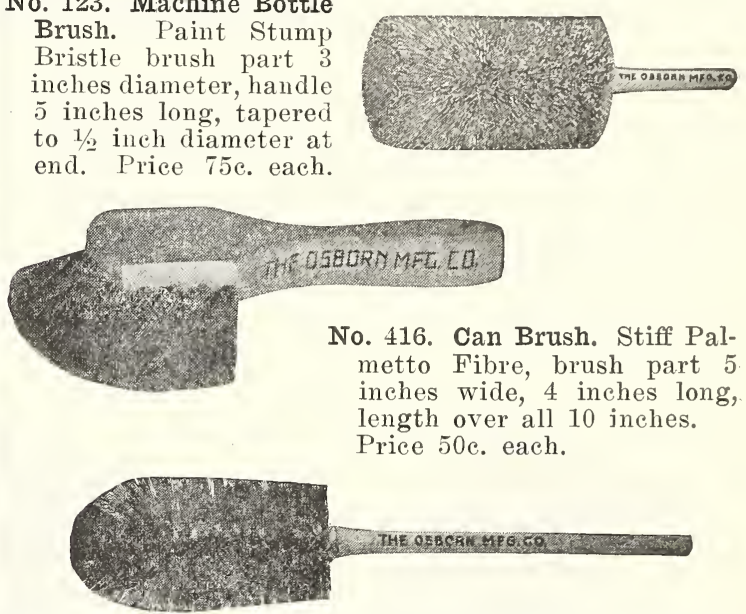

No. 86. Hand Bottle Brush. Pure Bristle, small size, handle 1/2 in. diameter, $10 \mathrm{ins}$. long. Price $75 \mathrm{c}$. each.

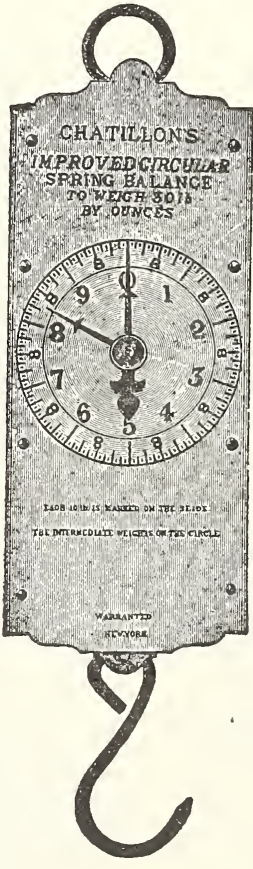

MILK SCALES

Chatillons Improved Circular Spring Balance Milk Scale. To weigh 60 lbs. sub-divided into tenths. Price $\$ 7.25$

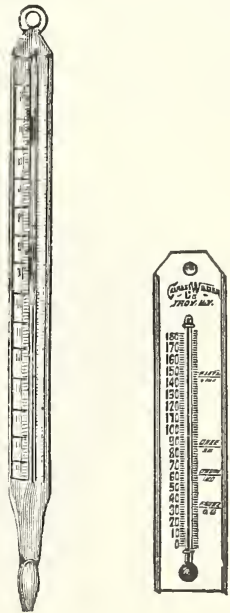

DAIRY THERMOMETERS

Floating Dairy. Postpaid, $\$ 1.00$.

No. 952 Floating Dairy. Postpaid 50c.

Churning Dairy. Postpaid, $\$ 1.00$.

Dairy Flange. Postpaid, $75 \mathrm{c}$. 


\section{We sell the famous Quaker}

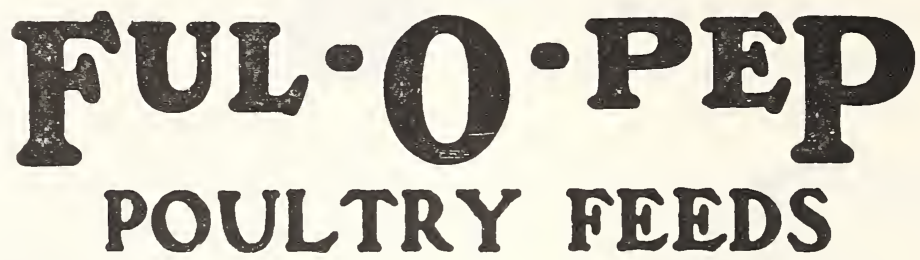

There's money in poultry when you feed these excellent rations according to FulO-Pep directions. They're the honest feeds, made from fresh, high-grade ingredients; every formula proved by scientific research and practical use. Made by the Quaker Oats Company, in big, clean, modern mills. Hundreds of Maine poultrymen testify to the economy of Ful-O-Pep Feeds.

\section{There's the RIGHT Ful-O-Pep Feed for Every Need, for Every Season}

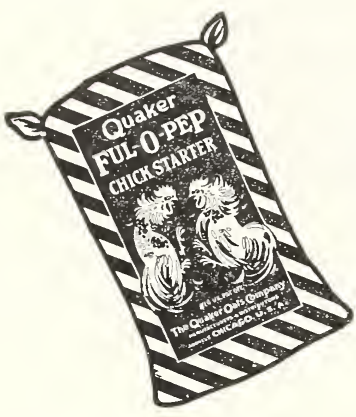

Ful-O-Pep Chick Starter; contains Cod Liver Oil and Cod Liver Meal. Saves the lives of baby chicks and gives them the right start.

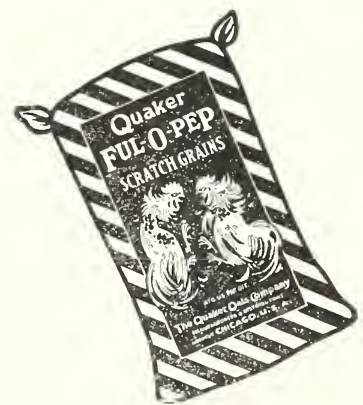

Ful-O-Pep Scratch Grains; a balanced mixture of only pure, choice grains - there's no waste when you use Ful-O-Pep Serateh Grains.

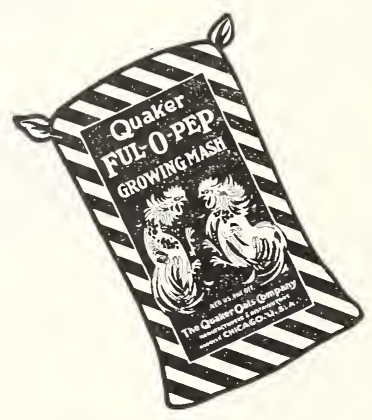

Ful-O-Pep Growing Mash; contains Cod Liver Meal. Gives young chicks big, husky frames so that they grow into fine market fowl, or exceptional layers.

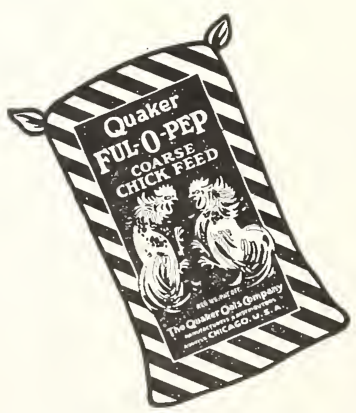

Ful-O-Pep Coarse Chick Feed; goes with Ful-O-Pep Growing Mash, providing a proper assortment of grains to help the Grow ing Mash build flesh, feathers, and bones. To be used according to Ful-O-Pep directions.

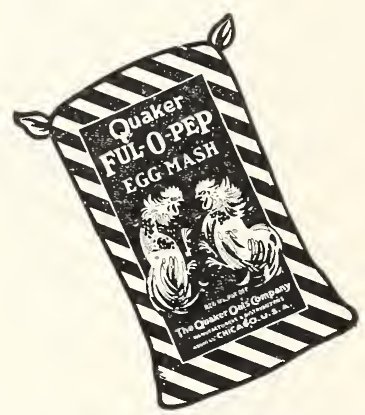

Ful-O-Pep Egg Mash; the feed that builds eggs; you get more eggs and better eggs at all seasons. Stronger shells, and chicks hatched from these eggs are strong and healthy.

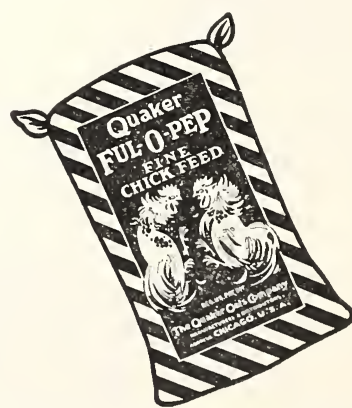

Ful-O-Pep Fine Chick Feed; a proper combination for use with Ful-O-Pep Chick Starter. Contains just the things baby chicks need, in the form they should have them.

We will be glad to hand you, without cost, a copy of the interesting and authoritative Ful-O-Pep poultry book, prepared by the poultry experts of the Quaked Oats Company. Ask for it. 


\section{POULTRY SUPPLIES}

\section{WELL KNOWN AGENCIES}

Newtown Giant Colony Brooders, Buckeye Incubators and Brooders, International Sanitary Hovers, United States Poultry Fence, Drew Line of Poultry Equipment, in fact a complete stock for the modern poultryman

(Write for Special Catalogues and Prices)

\section{THE ALUMINIZED METAL EGG CRATE}

Has proven itself, by its thousands of users, to be the only practical idea for shipping Eggs, Butter and other farm products by Parcel Post.

The Metal Fdge Elller is a wonder. A new invention and cannot be beat for safely carrying Eggs by mail. Light in weight and very strong.

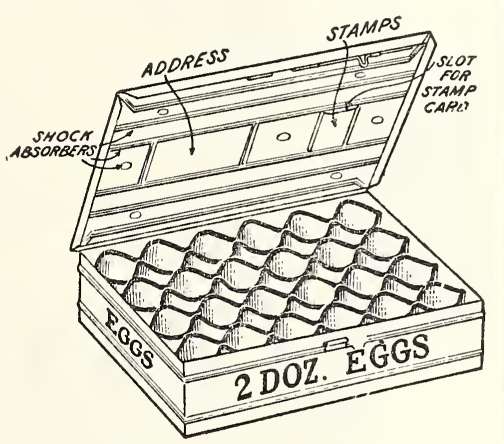

PRICES

$\begin{array}{lllll}11 / 2 & \text { doz. } & \text { size- } & \text { 6ll eggs } \\ 2 & 66 & 66 & 66 \\ 3 & \text { ، } & 66 & 66 & 66 \\ 4 & \text { 6 } & 66 & 66 & 66 \\ 6 & \text { 6 } & 66 & 66 & 66\end{array}$

$\begin{array}{rr}\$ 1.25 & \$ 1.32 \\ 1.50 & 1.57 \\ 1.75 & 1.83 \\ 2.00 & 2.09 \\ 2.50 & 2.60\end{array}$

"STERLING" PAPER EGG BOXES

These boxes are intended for use in delivering eggs to private families. They are of a very convenient size, are shipped knock-down and can be readily set up.
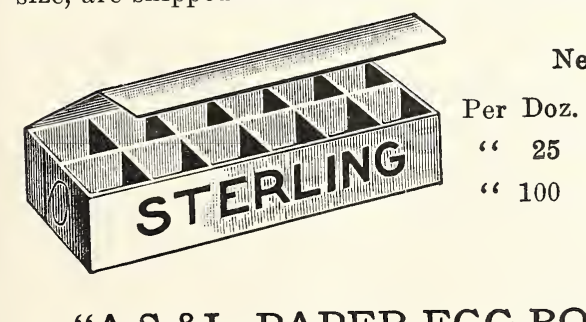

Net Price

\section{“A.S.\&L. PAPER EGG BOXES"}

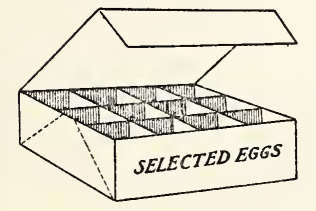

The old fashioned, nearly square, paper egg box. Stamp your name on the cover and guarantee the contents. It pays.

$\begin{array}{crr} & & \text { Price } \\ \text { Per Doz. } & & \$ 0.15 \\ \text { ، } & 25 & .30 \\ \therefore \quad 100 & & 1.15\end{array}$

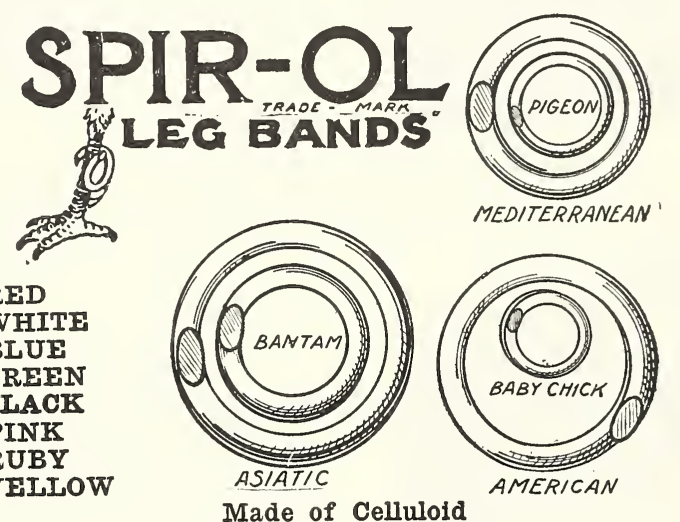

Identify birds as far as you can distinguish colors. Indestructible and can be slipped on and off like a key ring. Sample free. Poultry sizes: 12 for 10c., 25 for $20 \mathrm{c}$., 50 for $35 \mathrm{c}$., 100 for $50 \mathrm{c}$., postpaid. Baby Chick Bands: 25 for 20c., 50 for 35c., 100 for 60c., postpaid. Pigeon Bands - same price as chick.

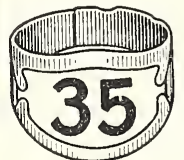

\section{THE VICTOR LEG BANDS}

In Colors with numbers

Made in celluloid and aluminum. Adjustable. Entirely new and different from all others. Large printed numbers, bright and clear colors. Red, blue, yellow and green. Prices: Prepaid by mail: 12 for 50c., 25 for $\$ 1.00,50$ for $\$ 1.85,100$ for $\$ 3.50$.

\section{PETTEY'S POULTRY PUNCH}

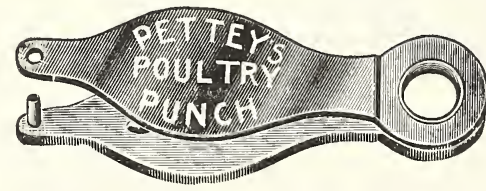

The best small chickmarker, and convenient to car. ry in the pocket. Postpaid 25c.

\section{WATER GLASS}

Put your eggs down in the spring and summer, when they are cheap, and keop them fresh for ten months. One gallon makes sufficient solution for 50 dozen. Do not trust eggs to water glass of inferior strength. Rutland water glass is pure and strong and safely protects the eggs.

Prices: 1 pint, $18 \mathrm{c} ., 1$ quart $25 \mathrm{c}$., gallon $90 \mathrm{c}$. 


\section{Sexton's Dry Feed Hopper} Easy to Fill. No Waste. Rat Proof. Dust-Proof

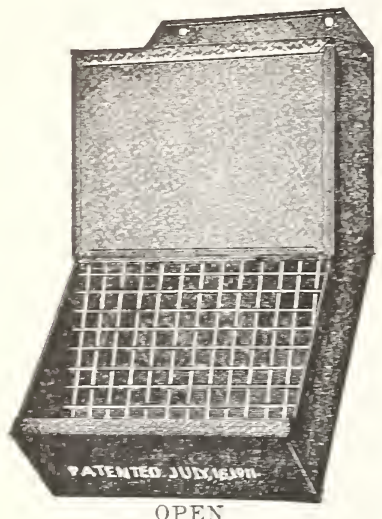

This Hopper is ar. ranged to hang on the wall the desired distance from the floor, and nerer need be remored from the wall to be refilled. It is impossible to waste any feed, as the pan at the bottom takes an feed that may be picked out and the last crumb can be used, therefore saring any maste. The body being corered keeps feed dust-proof and clean, and is always dry. Corer may be closed at night, making it ratproof.

Body made of galranized iron and the grating is of round galranized wire, prerenting the Poultrv from cutting their bills. Price, \$1.75. Parcel Post Paid, $\$ 1.90$.

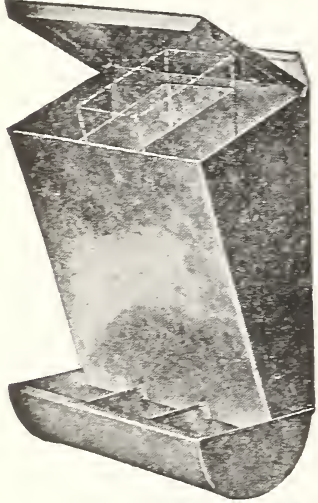

\section{Sexton}

\section{Shell and Grit Hopper}

Made of Galranized Iron, with portable partitions, so that the may be made into one, two, or three compart. ments as desired. Will not Clog. Price \$1.25. Parcel post paid $\$ 1.35$.

\section{THE DUPLEX FOUNTAIN}
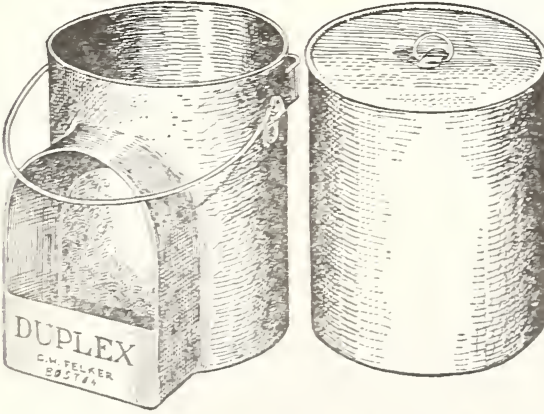

The lotest ard most Iractical staritars fountain on the market. This is a double fount. keeps the mater clean an i pure. Easr to fill. Easy to care for. 4-qts.. $\$ 1.15$. Parcel Post. Teight 3 lbs.; 8-qts., 1.35 , Parcel Post. Weight 41 is

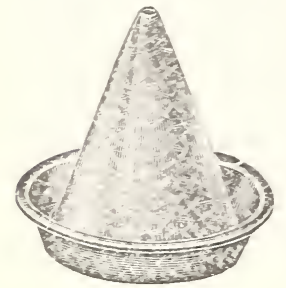

\section{NESCO SANITARY FOUNTAIN}

Galranized Pan and ConeShaped Top. Easily Cleaned. 1 qt. 35̄. By Parcel Post Prepaid, $40 \mathrm{c}$

\section{"CYMACO" Dry Mash Feeders} Solve Feeding Problems

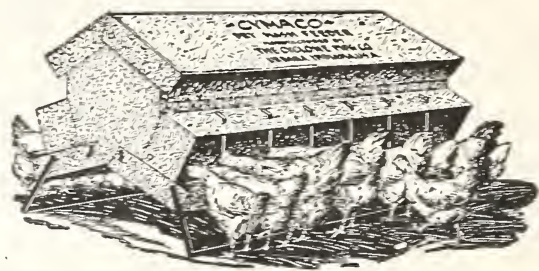

12 inch .............. \$2.25 Post paid $\$ 2.40$ 24 inch ............... 3.00 Post paid 3.25

McCandlish Roller Top Chick Trough

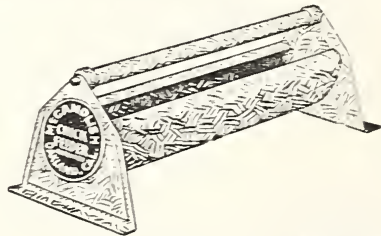

14 inch ............... \$.50 Post paid $\$ .55$ 28 inch ................. 75 Post paid .80

Junior Chick Feeder

FEEDS DRT MASH

OR HARD GRAIN

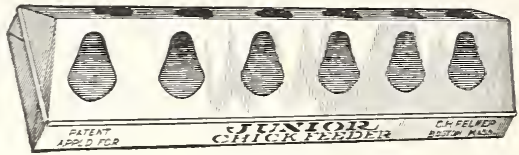

FEEDS SOUR MILK OR WATER

Made in two sizes. 12 inch, price $25 \mathrm{c}$., post paid 30c. 20 inch, price $40 \mathrm{c}$, post paid $45 \mathrm{c}$.

Moe's Double Feeding Troughs

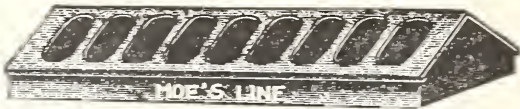

Double trough, with sliding top, easily filled and cleaned. Accurately stamped with dies. No rough edges.

No. 59 Length 18 in...... Each $\$ .60$ Postpaid \$.65

FELKER'S HANDY ATTACHMENT

To be used with anr make of Fruit Jar

A PERFECT FEEDER

For Sour Milk, Water, Hard Grain or Grit

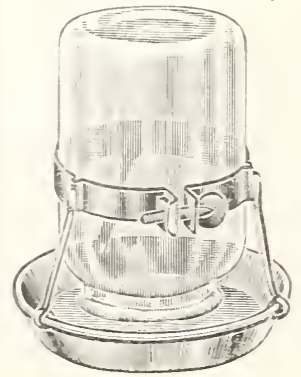

The Container is made of aluminum, the only metal in which sour milk can be fed with safetr. It is rust-proof and non-corroding. The Handy is adjustable, simple to operate and durable. Every one has some kind of a quart fruit jar - the Handy fits them all.

Price $25 \mathrm{c}$ each. 


\section{DR. HESS

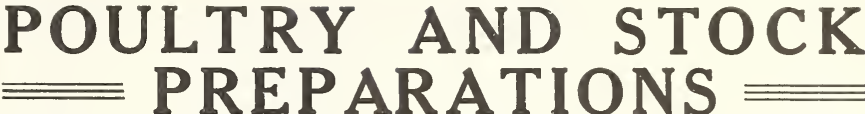

Prescriptions by Dr. Hess, M. D., D. V. S.

Dr. Hess Poultry Pan-a-ce-a

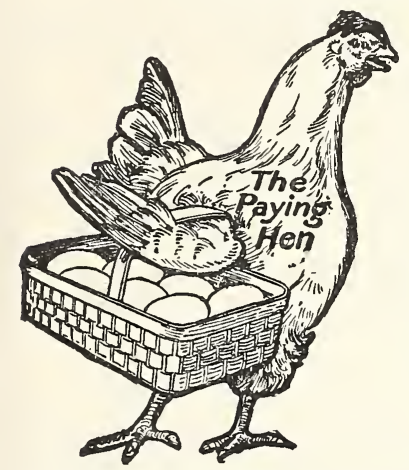

Makes poultry healthy; makes hens lay; not a stimulant, but a tonic that tones up the dormant egg Organs, brings back the scratch and cackle and compels each hen to put her share of eggs in the market basket.

It also contains internal antiseptics that counteract disease; insures a healthy, singing poultry flock. Costs but a trifle-a penny's worth enough for thirty hens per day.

11/2 lbs. 25c.; 5 lbs. 75c.; 12 lbs. $\$ 1.50$;

25 lb. pail $\$ 3.00 ; 100$ lb. drum $\$ 10.00$.

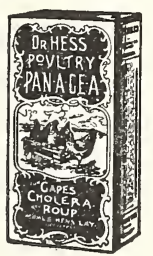

\section{Dr. Hess White Diarrhea Remedy}

For the prevention and treatment of White Diarrhea in chicks.

Price, 50c., postpaid 55c.

\section{Dr. Hess Roup Remedy}

For the treatment and prevention of Roup, Diphtheria and all catarrhal diseases of fowl.

Price, 10 oz. 50c., postpaid 55c.

Dr. Hess Dip and Disinfectant

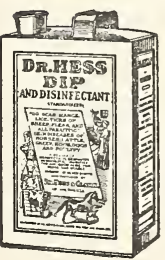

Non-poisonous and non-irritating, and guaranteed to be absolutely uniform in strength at all times. One gallon of Dip makes from 70 to 100 gallons effective solution. Spray it on roosts. Sprinkle it over the runs and in all cracks and crevices. Spray it on cattle and horses. Makes a splendid dip for hogs and sheep. It's a sure parasite and disease germ destroyer. Purifies stables, troughs, sinks, drains.

Household size 50c., Qt. 75c., 2 Qts. $\$ 1.25$, Gal. $\$ 2.00$.

\section{Dr. Hess Instant Louse Killer}

Kills lice on poultry, horses, cattle; sheep ticks; bugs on cucumber, squash and melon vines; cabbage worm, slugs on rose bushes, etc. Sold in siftingtop cans. Look for the word "Instant" before buying.

PRICE, 1 lb. 25c., 21/2 lbs 50c.

Dr. Hess Stock Tonic

Formula printed on every package

Every ingredient indorsed by the U. S. Dispensatory and other high medical authorities. It aids digestion, makes stock healthy, and expels worms. Helps stock convert more ration into milk, flesh, blood and muscle. Every pound backed by the Dr. Hess \& Clark unqualified guarantee.

$3 \frac{1}{2}$ lbs. 50c., 10 lbs. $\$ 1.25,25$ lb pail $\$ 3.00$, $100 \mathrm{lb}$. drum $\$ 10.00$.

\section{Dr. Hess Healing Powder}

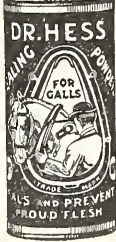

The modern gall cure. Cures galls, cuts, wounds, ulcers, grease heel. Antiseptic and soothing. Heals everything it touches by forming a coating, cleaning and closing up wounds.

Comes in sifting-top cans.

PRICE, 4 oz. 25c.; 10 oz. 50c.

Dr. Hess Heave Powder

A dependable preparation for relieving horses of heaves, chronic coughs, asthma, bronchitis, etc.; with careful diet, the frequent use of this valuable preparation will afford permanent relief in the majority of cases.

PRICE, 11/2 lb. package 50c.
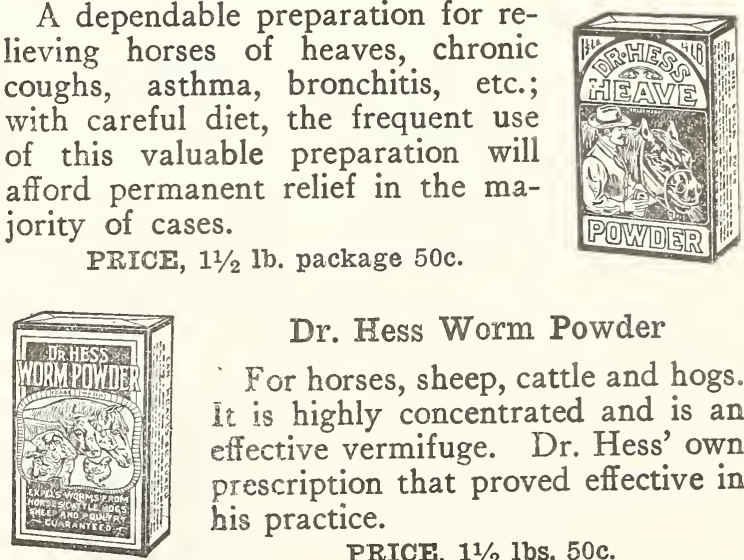

\section{Dr. Hess Worm Powder}

For horses, sheep, cattle and hogs. It is highly concentrated and is an effective vermifuge. Dr. Hess' own prescription that proved effective in his practice.

PRICE, 11/2 1bs. 50c. 


\section{INSECTICIDES AND FUNGICIDES}

Ansect. A liquid rose bug destroyer. Dilute $4 \mathrm{oz}$. can in gal. water. $4 \mathrm{oz}$. can $25 \mathrm{c}$.

Ant Killer. Powder. 41/2 oz. can $40 \mathrm{c}$.

Arsenate of Lead. (Dry.) Used either as a spray or dust for all leaf-chewing worms and insects. It will not burn or injure your crop. 1/2 lb. 20c., $1 \mathrm{lb}$. 30 c., 4 lbs. $\$ 1.00,25$ lbs. $\$ 5.50,100$ lbs. $\$ 20.00$.

Black Leaf 40. (Nicotine Sulphate.) Highly recommended by spraying experts for destroying all sucking and many chewing insects. 1 oz. $35 \mathrm{c} ., 1 / 2$ lb. $\$ 1.25,2$ lbs. $\$ 3.50,10$ lbs. $\$ 13.50$.

Bordeaux Mixture, Dry. Can be used either dry as a dust or mixed with water as a spray for all fungous diseases. $1 \mathrm{lb}$. to 5 gals. of water. $1 \mathrm{lb}$. 30c., $4 \mathrm{lbs}$. $85 \mathrm{c} ., 25 \mathrm{lbs} . \$ 4.50$.

Bug Death. A non-poisonous powder. Destroys potato, squash, and cucumber bugs, currant and tomato worms; safe to handle. Contains no Paris Green or Arsenic. Apply dry or in water. 1 lb. 20c., 3 lbs. 45c., 5 lbs. 65c., $12 \frac{1}{2}$ lbs. $\$ 1.25,100-\mathrm{lb}$. keg $\$ 8.50$.

Bug Death Alpha (formerly called Aphis). For sucking insects, lice, aphis, flea beetles, and fungus. 12 oz. pkg. 20c., 10 lbs. \$1.25, 80 lb. drums $\$ 8.50$.

Carbola. A combined disinfectant and paint, or whitewash. One pound paints and disinfects 250 square feet. 5 lbs. 75 c., 10 lbs. $\$ 1.25,25$ lbs. $\$ 2.75,50 \mathrm{lbs}$. $\$ 5.00$.

Copper sulphate. For making home-made bordeaux mixture for fungicide purposes. Write for price.

Cut Worm Killer. A powder to be sprinkled on ground an inch or two from plants. Sure death to cut worms. 1 lb. 40 c., 5 lbs. $\$ 1.50$.

Dolge Liquid Weed Killer. Destroys weeds in paths, roads and gutters. Dilute 1 part Weed Killer to 40 parts of water and apply with sprinkling can or cart. 1 qt. can $75 c ., 1$ gal. can $\$ 2.00,5$ gal. can $\$ 6.50$.

Formaldehyde (Liquid). For destroying the germs that affect animal and plant life; also as a preventive for potato scab. Dilute one pound in forty gallons of water. $1 \mathrm{lb}$. bottle $50 \mathrm{c}$.

Hall's Nicotine Fumigator. An efficient insecticide prepared especially for fumigating greenhouses. Destroys plant lice and similar soft bodied insects. $21 / 2$ lb. eans $\$ 2.50$ each, $10 \mathrm{lb}$. can $\$ 8.50$.
Hellebore (Powdered). Safe to use when fruit or vegetables are nearly ripe. Used largely for cabbage and currant worms, can be used as a powder or dissolved. 1/2 lb. 25c., 1 lb. $45 \mathrm{c}$.

Kerosene Emulsion. It kills the green plant louse, scale and most soft bodied and sucking insects. 1 pt. cans 25c., 1 qt. cans $40 \mathrm{c}$.

LA-LO Animal Spray. This spray is invisible even on white cattle. Has a mild, pleasant odor. Will not gum the hair. Will not irritate or blister. Will not taint milk-even if used freely at milking time. Assists in keeping cows free from flies and mosquitoes in summer and lice in winter. 1 gal. can $\$ 2.00$.

Melrosine. The general contact insecticide that kills rosebugs and other insects. Used with any good spray-pump, diluted with from 20 to 25 parts of water. Pleasant and harmless to use. One pint will make three gallons of spray solution. Pint $\$ 1.00$; quart $\$ 1.75$.

Nico-Fume (Liquid). Used as a spray or as a vapor. Does not stain nor injure blooms. $1 / 4 \mathrm{lb}$. can $75 \mathrm{c}$., $1 \mathrm{lb}$. can $\$ 2.35,4 \mathrm{lb}$. can $\$ 8.50,8 \mathrm{lb}$ can $\$ 16.50$.

Paris Green. Used for potato bugs. 1/2 lb. $30 \mathrm{c} ., 1 \mathrm{lb} .55 \mathrm{c}$.

Pyrox, Bowker's. The one best spray for all leaf-eating insects. Does all that Arsenate of Lead will do, besides protecting trees, shrubs, vegetables and plants against fungous diseases, one application answering both purposes, saving labor and expense. All ready to use by adding water. Lb. 50c., $5 \mathrm{lbs}$. $\$ 1.75,10$ lbs. $\$ 3.00,25$ lbs. $\$ 6.25,50$ lbs. $\$ 10.75$, 100 lbs. $\$ 17.00$.

Scalecide. The complete dormant spray. It keeps trees clean and healthy, and effectively takes care of the leaf roller, bud moth, case bearer, San Jose scale, and all kinds of scale. Write for special catalogue. Qt. 60c., gal. $\$ 1.45,5$ gals. $\$ 6.25,10$ gals. $\$ 11.00,30$ gals. $\$ 26.00,50$ gals. $\$ 38.00$.

Tobacca Dust. For dusting green and black aphis, fleas, etc. Write for price.

Toxol. A non-poisonous and non-explosive liquid. Kills flies, mosquitoes, lice, spiders, water bugs and other insects. Pint can 65c., quart can $\$ 1.10$.

Tree Tanglefoot. A sticky compound for painting around the trunks of trees, in the form of a band, the most effective and economical protection against crawling insects. Caterpillars and other crawling pests cannot get over it. $1 \mathrm{lb} .60 \mathrm{c} ., 5 \mathrm{lbs}$. $\$ 2.75,10$ lbs. $\$ 5.25$.

Volck. A spray for the garden, nursery and greenhouse; effectively controls red spider, mites, white flies, scales, mealy bugs, caterpillars, aphis, thrip, etc.; not only kills the insects but also acts as a repellant. $\$ 3.00$ per gal. 


\section{NIAGARA DUST FORIULAS AND USES}

Niagara Soluble Sulphur Compound. The cheapest spray for the dormant and delayed dormant applications. Particularly effective against San Jose Scale, the worst enemy of American fruit. Equally effective against all other scale insects, Peach Leaf Curl, and many other pests. Only $12 \frac{1}{2}$ lbs. is needed in 50 gallons of water to get effective results. Lb. 35c., 5 lbs. $\$ 1.00,10$ lbs. \$1.75, 25 lbs. $\$ 3.50,50$ lbs. $\$ 6.00,100$ lbs. $\$ 10.00$.

Niagara A-1 Mixture. For Aphids, Red Bugs. Pear Psylla, etc. The best contact dust for sucking insects. $25 \mathrm{lbs} . \$ 4.75,50 \mathrm{lbs}$. $\$ 9.00,100 \mathrm{lbs} . \$ 16.00$.

Niagara D-6 Mixture. Dehydrated Copper Sulphate 20 per cent (as Copper Sulphate Crystals 26.7\%) Lime and filler. Standard Copper Fungicide without poison for potatoes, celery, and other vegetable crops. 25 lbs. $\$ 2.75,50$ lbs. $\$ 4.75,100$ lbs. $\$ 7.50$.

Niagara D-20 Mixture. Dehydrated Copper Sulphate 20 per cent (as Copper Sulphate Crystals 26.7\%) Calcium Arsenate (poison) 20 per cent, Lime and Filler. Standard Copper Fungicide with poison for Potato Bugs and Blight. $25 \mathrm{lbs} . \$ 3.25,50 \mathrm{lbs} . \$ 6.25$, 100 lbs. $\$ 10.00$

Niagara Super-Sulfodust. Dusting Sulphur with special spreader and sticker. Fineness $98 \%, 300$ mesh. An Improved Sulphur Fungicide without poison for Apple Scab, Brown Rot, etc. 100 lbs. \$4.25.

Niagara Kolodust. A new patented dusting sulphur of infinite fineness. A dust you can see stick. The New Exclusive Niagara Sulphur Fungicide without poison for Apple Scab, Brown Rot, etc. 100 lbs. $\$ 5.00$.

Niagara Fruitex Dust. Sulphur and Lead Arsenate Mixture. For Diseases of Apples, Pears, etc.; Codling Moth, Strawberry Weevil, etc. 100 lbs. $\$ 8.25$.

Niagara Kolotex. A mixture of Kolodust and Lead Arsenate. A dust you can see stick. The New Exclusive Niagara Sulphur Fungicide with Lead Arsenate for Diseases of Apples, Pears, etc.; Codling Moth, Strawberry Weevil, etc. 100 lbs. $\$ 8.00$.

Niagara 'Six Little Dusts.', for the small garden, in convenient $1 \mathrm{lb}$. cans.

Per can

No. 1. Entodust. Controls plant eating insects. $\$ .40$ No. 2. A-1 Dust. Controls sucking insects..... .60 No. 3. D-6 Dust. Controls blight, mildew, fun-

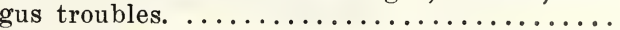
No. 4. Pomodust. Controls rose bush troubles. No.5. D-20 Dust. Insecticide and Fungicide

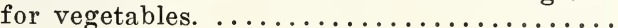
No. 6. All-in-one. General dust. ...........

Write us for The Niagara Garden Police Book.

\section{NIAGARA HAND PLUNGER GUN}

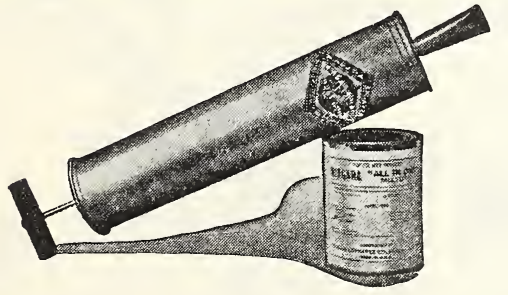

A practical duster for small gardens, rose bushes, shrubs, or in any place where the various dry powders are to be applied in small quantities.

\section{NIAGARA BLOWER DUST GUN}

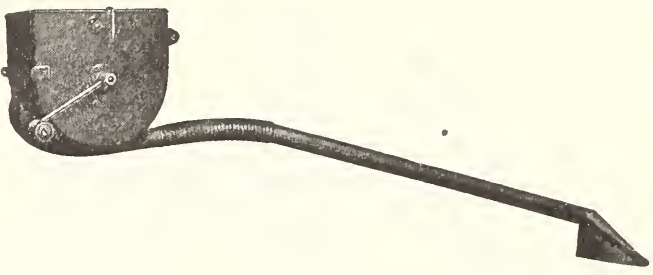

The nozzle is attached directly to flexible tube for dusting plants waist high. The right hand turns the crank.

Straps go over shoulders, cross on the back and attach to the side of hopper. One section of pipe added to flexible tube for dusting plants knee high.

Two sections of pipe added with flexible tube at nozzle-end for dusting strawberries, cucumbers, etc. The dense cloud of dust reaches all parts of foilage.

Price $\$ 22.00$

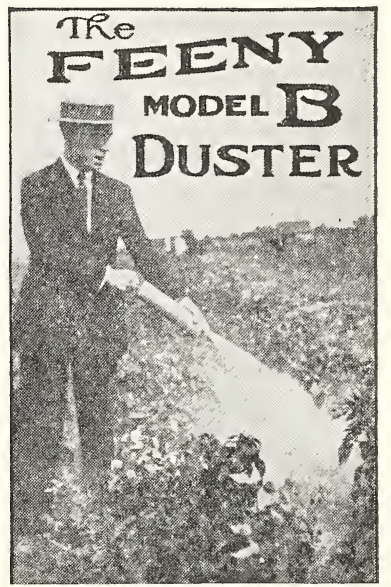

No other duster has the patented piston packing features of the Model B Duster. These features allow of the greatest moving volume of air and the greatest force with the least possible mechanical friction, insuring the easiest o p e r a t io $\mathrm{n}$. With the Model B, the slightest movement forward of the piston, produces a dust cloud of the highest type. This is due to the perfect compression which is accomplished in no other dusting device.

Price, $\$ 1.00$.

Post Paid, $\$ 1.10$

\section{DICKEY BUG DEATH DUSTER}

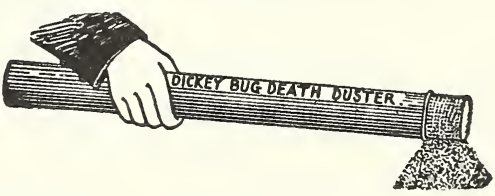

For use in applying BUG DEATH, DRY to small flower or vegetable gardens. Price 45c., Postpaid 50c.

\section{THE B. D. BUG DEATH SIFTER}

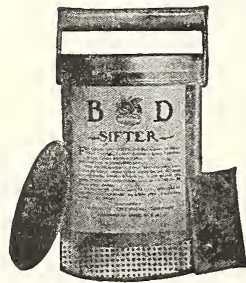

The B. D. Sifter is the latest hand device for applying BUG DEATH.

Easy to operate and gives quick covering to all plants and vines requiring a top application. Price 65c., Postpaid 75c. 


\section{HUDSON IDEAL SPRAYER}

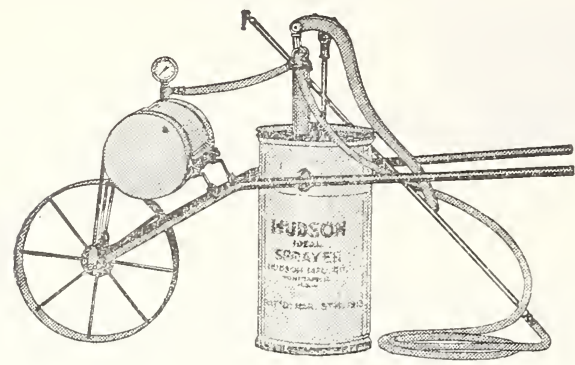

The Hudson Ideal Sprayer is a high pressure portable outfit, capable of developing a pressure of 200 pounds. Capacity of tank 15 gallons. Shipping weight 100 pounds. No. 33 Ideal Sprayer ........... Price, $\$ 33.00$ each

\section{HUDSON PERFECTION SPRAYER}

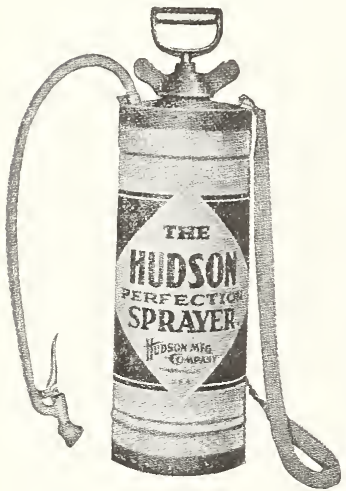

For gardening, whitewashing and general use. Capacity about four gallons.

Perfection, galvanized. Price each, $\$ 6.00$

Perfection, brass.

Price each, $\$ 8.50$

Hudson Junior similar to the Perfection but smaller. Tank holds about 21/2 gallons.

Galvanized Junior.

Price, $\$ 4.50$ each

\section{HUDSON TROIMBONE SPRAYER}

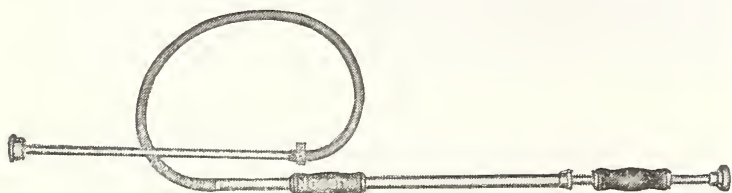

The Hudson Trombone Sprayer is a high pressure spray pump adapted for spraying orchards, shrubbery, shade trees, potatoes and field crops.

It is double acting, maintaining a steady discharge without undue exertion on the part of the operator.

No. 123. Hudson Trombone Sprayer...Price, $\$ 4.50$ each

\section{HUDSON MISTY SPRAYER}

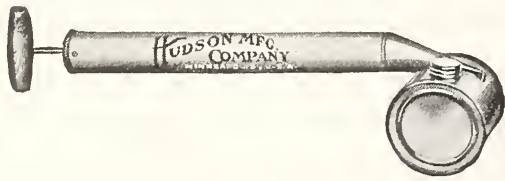

The Hudson Misty Sprayer is a favorite with the housewife. It is suitable for use in a small garden, around the dairy barn, chicken coops, etc.

Misty Sprayer, eapacity one quart. .... Price, 50c each Midget Sprayer, capacity one pint. .... Price, 35c each

\section{PlanetJr GARDEN TOOLS}

"A tool for every need."

Send for Planet Jr. Catalogue of the complete linefree on request.

We carry in stock all the latest models but list below only a few of the most popular.

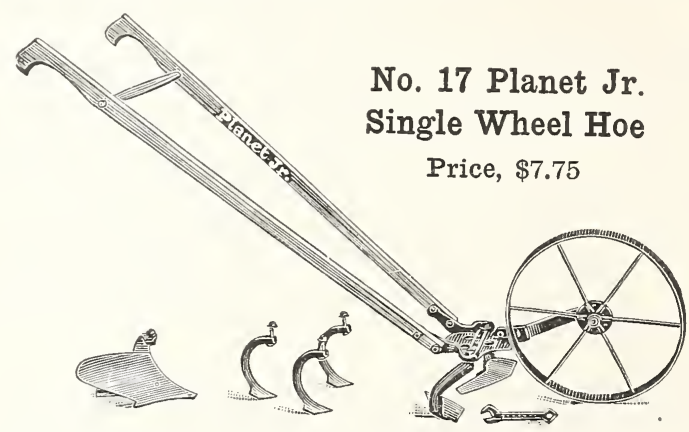

The No. 17 has a pair of 6 -inch hoes, a plow and a set of 3 cultivator teeth, as illustrated above.

No. 4 Planet Jr. Combined EIill and Drill Seeder, Wheel Hoe, Cultivator and Plow

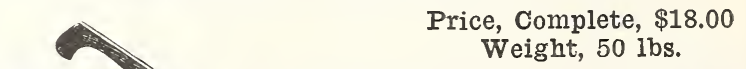

No. 4D. As a Seeder only, \$14.25. Holds $21 / 2$ Quarts of Seed

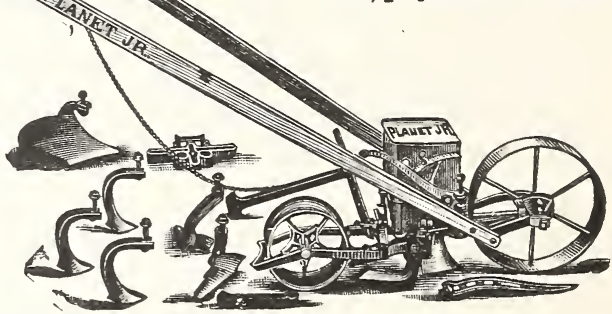

For use as a cultivator, the drill parts are removed and the tool frame substituted by changing but one bolt; it is then a perfect single wheel hoe, with a variety of tools.

No. 8 Planet Jr. Combined Horse Hoe and Cultivator

Price, with Steel Wheel,

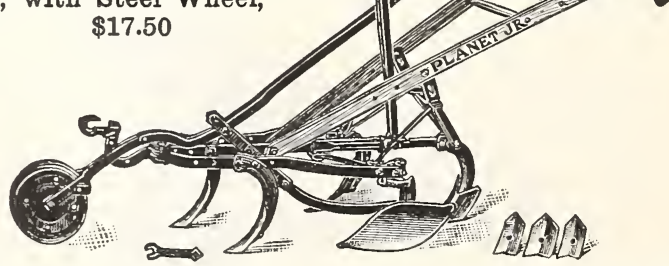

Equipment: Four $3 \times 8$-in. plates, one $4 \times 8$-in. plate, two 6-in. side hoes, one 7-in. shovel, level wheel, lever expander. Depth regulator.

This is a general favorite. Easily understood and operated. The tool is especially strong; braced to make a stiff, unyielding tool intended for long service. 
STANDARD FLOWER POTS

Earthenware

$\begin{array}{llr} & & \text { Each } \\ 2 & \text { inch } & \$ .02 \\ 21 / 2 & \text { 66 } & .03 \\ 3 & 66 & .05 \\ 31 / 2 & 66 & .06 \\ 4 & 66 & .07 \\ 5 & 66 & .09 \\ 6 & 66 & .12 \\ 7 & 66 & .25 \\ 8 & 66 & .30 \\ 9 & 66 & .45 \\ 10 & 66 & .60\end{array}$

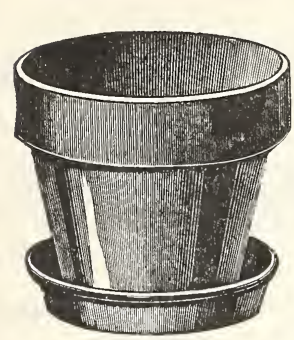

Doz.

.25

.40

.45

.50

.85

1.20

2.00

2.75

4.00

5.40

FLOWER POT SAUCERS

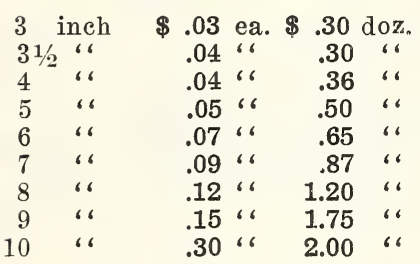

\section{BUI B PANS}

Earthenware

4
5
6
7 Each

Doz.
$\$ .50$

$\$ .07$

.15

.25

.30

.45

.60

1.50
$\$ \begin{array}{r}\text { Doz. } \\ .50 \\ .75\end{array}$

1.50

2.00

3.00

4.50

6.00

13.00

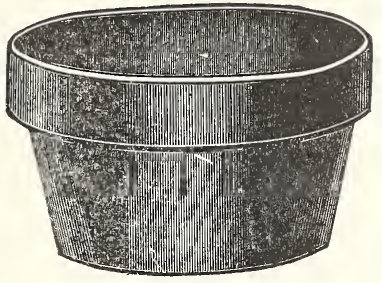

\section{NEPONSET PAPER FLOWER POTS}

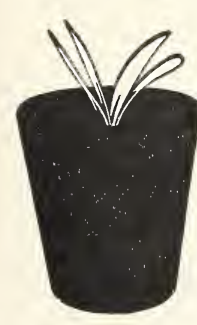

The Neponset Paper Flower Pot is a waterproof paper pot made from a tough fibre paper, and is especially adapted to the florist, gardener and nursery trade.

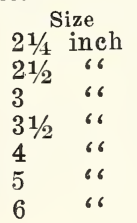

Doz.
$\$ .10$
.12
.15
.18
.25
.35
.40

$\$ \begin{array}{r}100 \\ \$ .50\end{array}$

.60

.90

1.00

1.25

2.00

2.75

\section{PAINTED WOOD LABELS}

$\begin{array}{rrrrr} & & & 100 & 1000 \\ 4 & \text { in. Pot } & \$ 0.25 & \$ 1.70 \\ 41 / 2 & \text { 66 66 } & .30 & 1.90 \\ 5 & \text { ، } & \text { 6 } & .35 & 2.10 \\ 6 & \text { 6 } & \text { 6 } & .40 & 2.50 \\ 10 & \text { 6 } & \text { 6 } & .75 & 5.40 \\ 12 & \text { 6 } & \text { 6 } & .95 & 6.60 \\ 8 & \text { 6 Garden } & .80 & 6.50 \\ 10 & \text { 6 } & \text { 6 } & 1.00 & 8.00 \\ 12 & \text { 6 } & \text { 66 } & 1.35 & 11.00\end{array}$

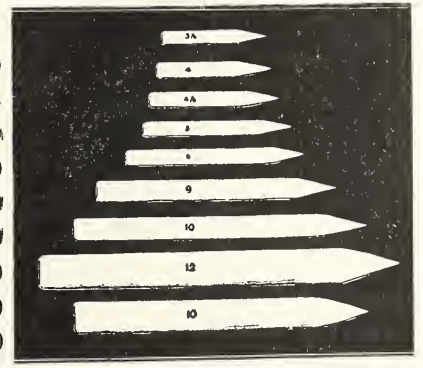

$31 / 2$ in. Copper Wired Labels

\section{THE “HARRIS READY-TO-USE” LOCKED PLANT BAND}

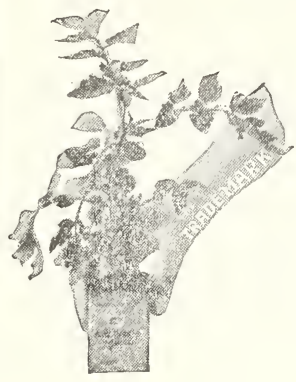

The principle evolved in the Plant Band is not a new one. The one feature which has prevented the general use of plant bands has been the time and labor required in making them up by hand. This disadvantage has been entirely eliminated by the bands which this Company offers to the trade, which are truly what the name implies "Ready-ToUse."

Size $2 " \times 2 " \times 21 / 2$.

Carton 250, $\$ 1.00$. Less than carton 1 cent each.

The Florist's Bull Dog Package Clip

Made of tempered steel, polished, unsurpassed for Florist's use, easily and quickly adjusted. Saves its cost in time and labor many times over.

Packed in Boxes of 1,000-price, 75c. per thousand.

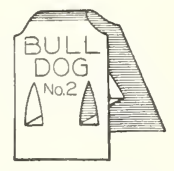

Exact Size net weight 2 oz. per 1,000 clips.

\section{GREEN DYED BAIMBOO STAKES}

Length Diameter Doz. 100 $2 \mathrm{ft} .1 / 4$ in. $\ldots \ldots \ldots \ldots \ldots \ldots \ldots \ldots+\$ 0.12 \quad \$ 0.75$

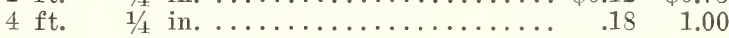

\section{HEAVY PLAIN BAIMBOO STAKES}

Length Diameter Doz. 100

46 in. $1 / 2$ in. ................ \$0.55 \$3.50

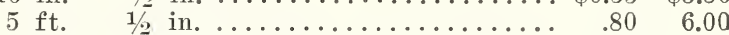

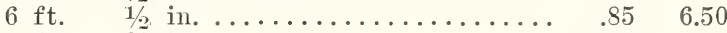

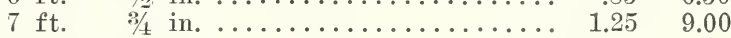

\section{PANSY AND VERBENA BASKETS}

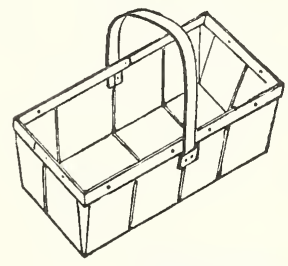

Size-10 inches long, 5 inches wide, 3 inches deep.

$\$ 3.00$ per $100, \$ 27.00$ per 1000 .

Size-12 inches long, 7 inches wide, 4 inches deep.

$\$ 4.00$ per 100 , $\$ 35.00$ per 1000 .

\section{PEERLESS GLAZING POINT}

(Improved Van Reyper.)

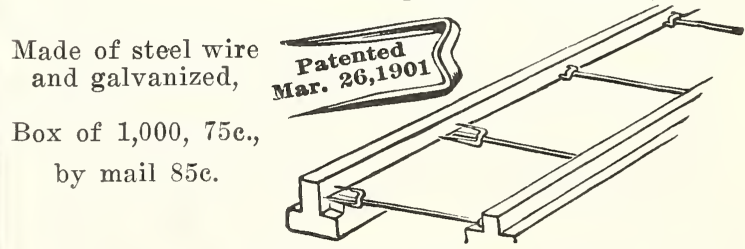

\section{HOTBED MATS}

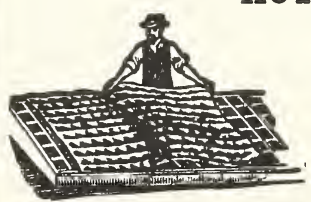

Made by hand of rye straw. Size 6 × 6 ft., each, $\$ 2.50$. 


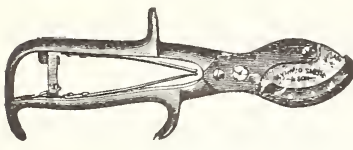

Pruning Shears

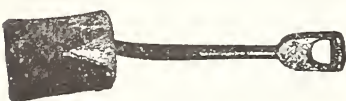

Shovel

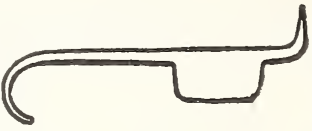

Grafting Chisel

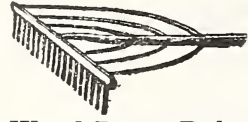

Wood Lawn Rake
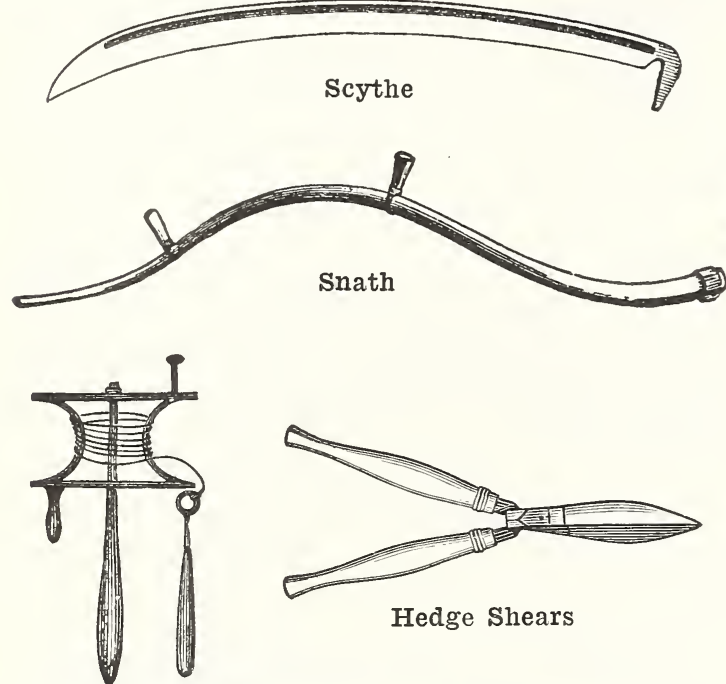

Hedge Shears

Garden Line Reel

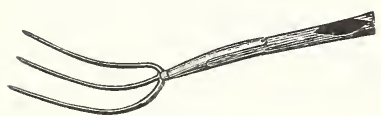

Hay Fork

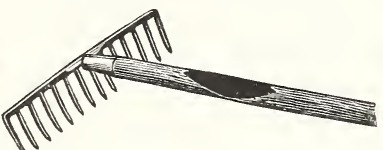

Garden Rake

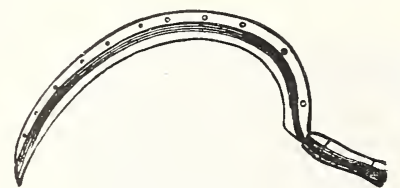

Grass Hook

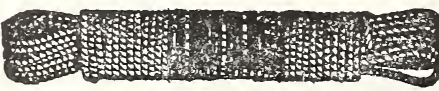

Garden Line

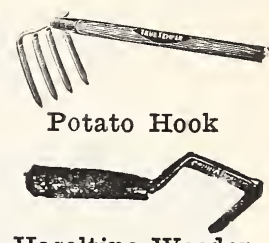

Haseltine Weeder

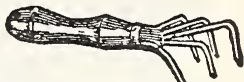

Excelsior Weeder

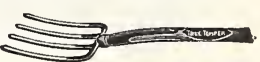

Spading Fork

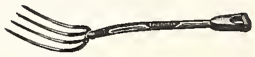

Manure Fork

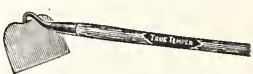

Garden Hoe
Asbestos Torch

Attach the torch to the end of a pole of suitable length; saturate with kerosene oil, light, and hold under the nests...........40c.

Asparagus Knife

Made of Solid Steel. Goodell Dou-

ble Point, P. P. Weight 1 lb...40c.

Edging Knife

Long handle ...........\$1.15

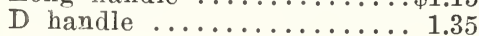

Forks

Manure, 4 Tine D handle... \$1.75

5 Tine $\mathrm{D}$ handle.......... 2.00

6 Tine $\mathrm{D}$ handle.......... 2.25

Hay, 3 Tine (all lengths of han-

dle) .....................

Spading, 4 Tine $\mathrm{D}$ handle... $\$ 2.00$

4 Tine long handle ....... 1.60

Fruit Picker

Grafting Chisel

Made from the finest cast steel. 75c.

Grafting Wax (Trowbridge)

The best on the market. $1 / 4 \mathrm{lb}$. pkg. 15c., 1/2 lb. pkg. 25c., 1 lb. pgk. $40 \mathrm{c}$.

Garden line

Italian Hemp, 100 feet ....\$1.25

\section{Garden Line Reel}

\section{Grass Hooks}

Meadow King ............35c.

Nolan ................... 85 .

Hoes

8 in. Meadow .........\$1.20

9 in. Meadow ................ 1.25

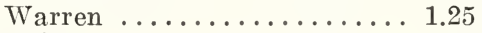

Onion $\ldots \ldots \ldots \ldots \ldots \ldots \ldots \ldots \ldots \ldots \ldots$

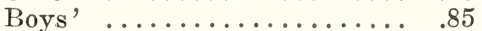

Ladies, ................ .75

Potato Hooks

5 Tine ............. $\$ 1.40$

6 Tine ................ 1.50

Pruning Saws

Disston No. $9 \ldots \ldots \ldots \ldots . \$ 2.25$

Disston No. 15 .......... 3.00

Scythes

Grass .............\$1.75

Bush ...................... 1.75

Scythe Snaths

Regular ............\$1.50

Bush ..................... 1.75

Shears, Pruning

Taylor Pattern, with coil spring,

9 inches ............\$0.60

California Pattern, with volute

spring, 9 inches ......... $\quad .85$

Swiss Pattern, polish, 9 inches 1.75

Levin Pattern, 7 inches .... .50
Shears, Hedge

9 inch notched .........\$2.75

6 inch ladies' .............. 2.00

Scuffle Hoes

8 inch blade

Shovels

D Handle, Square or Round Point. Long Handle, Square or Round

Point, each $\$ 1.25, \$ 1.50$ and $\$ 1.75$ Spades

D Handle ............\$1.50

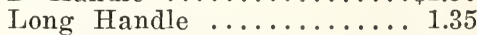

Ames' Best .............2. 200

Trowels

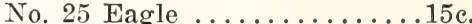

No. 809 Solid Steel ........25c.

No. 100 Socket Pattern ......40c.

Keystone 6 inch .........75c. Weeders

Excelsior .............20c. Haseltine .....25 Midget Norcross. Short handle for hand work ................40e. 3-Prong Noreross. Light and can be used by women and children $85 \mathrm{c}$. 5-Prong Norcross. The standard size. A wonderfully useful tool. Every man with a garden should have one.

Magic. Several styles priced from $15 \mathrm{c}$. to $\$ 1.10$ each. 


\section{PLANTING TABLE}

Quantity of Seeds or Number of Plants Required for a Rcw 100 Feet in Length, with Distance to Plant and Tyme for Planting

\begin{tabular}{|c|c|c|c|c|c|c|}
\hline \multirow{2}{*}{ Find of Vegetablo } & \multirow{2}{*}{$\begin{array}{l}\text { Seeds or Plente } \\
\text { Required for } \\
100 \text { Feet } \\
\text { of Row }\end{array}$} & \multicolumn{2}{|c|}{$\begin{array}{c}\text { Distance for Plants to Stand } \\
\text { Hand Cultivation }\end{array}$} & \multirow{2}{*}{$\begin{array}{l}\text { Depth of } \\
\text { Planting }\end{array}$} & \multirow{2}{*}{ Time of Planting in Open Ground } & \multirow{2}{*}{$\begin{array}{l}\text { Ready for Ose } \\
\text { After Planting }\end{array}$} \\
\hline & & Rows Apart & in $\mathrm{Ro}$ & & & \\
\hline 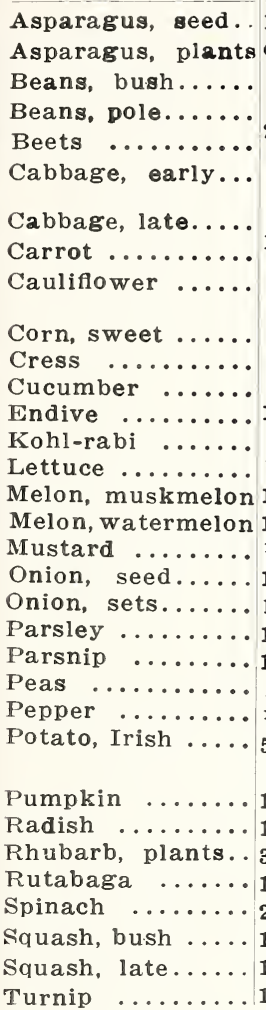 & $\begin{array}{l}1 \text { ounce } \\
60-80 \text { plents } \\
2 \text { pounds } \\
1 \text { pound } \\
2 \text { ounces } \\
1 / 2 \text { ounce } \\
1 / 2 \text { ounce } \\
1 \text { ounce } \\
1 / 2 \text { ounce } \\
1 \text { pound } \\
1 / 2 \text { ounce } \\
1 / 2 \text { ounce } \\
1 \text { ounce } \\
1 / 2 \text { ounce } \\
1 / 2 \text { ounce } \\
1 \text { ounce } \\
1 \text { ounce } \\
1 / 2 \text { ounce } \\
1 \text { ounce } \\
1 \text { quart of sets } \\
1 \text { ounce } \\
1 \text { ounce } \\
2 \text { pounds } \\
1 / 2 \text { ounce } \\
5 \text { lbs. (or } 9 \\
\text { bu. per acre) } \\
1 \text { ounce } \\
1 \text { ounce } \\
33 \text { plants } \\
1 \text { ounce } \\
2 \text { ounces } \\
1 \text { ounce } \\
1 \text { ounce } \\
1 \text { ounce }\end{array}$ & $\begin{array}{l}30 \text { to } 36 \mathrm{in} . \\
12 \text { to } 18 \mathrm{in} . \\
4 \text { to } 6 \mathrm{ft} . \\
18 \mathrm{in} . \\
18 \text { to } 24 \mathrm{in} . \\
12 \text { to } 18 \mathrm{in} . \\
6 \text { to } 8 \mathrm{ft} . \\
8 \text { to } 12 \mathrm{ft} . \\
12 \text { to } 18 \mathrm{in} . \\
12 \text { to } 18 \mathrm{in} . \\
12 \text { to } 18 \mathrm{in} . \\
12 \text { to } 18 \mathrm{in} . \\
18 \text { to } 24 \mathrm{in} . \\
30 \text { to } 36 \mathrm{in} . \\
18 \text { to } 24 \mathrm{in} . \\
24 \text { to } 36 \mathrm{in} . \\
8 \text { to } 12 \mathrm{ft} . \\
12 \text { to } 18 \mathrm{in} . \\
3 \text { to } 5 \mathrm{ft} \text {. } \\
18 \text { to } 24 \mathrm{in} . \\
12 \text { to } 18 \mathrm{in} . \\
3 \text { to } 4 \mathrm{ft} \text {. } \\
7 \text { to } 10 \mathrm{ft} . \\
18 \text { to } 24 \mathrm{in} .\end{array}$ & 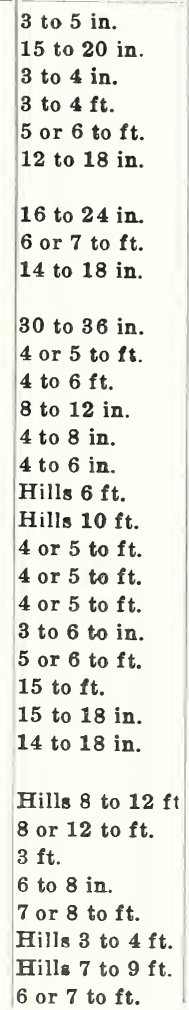 & $\begin{array}{l}1 \text { to } 2 \text { in. } \\
3 \text { to } 5 \text { in. } \\
1 \text { to } 2 \text { in. } \\
1 \text { to } 2 \text { in. } \\
1 \text { to } 2 \text { in. } \\
1 / 2 \text { in. } \\
1 / 2 \text { in. } \\
1 / 2 \text { in. } \\
1 / 2 \text { in. } \\
1 \text { to } 2 \text { in. } \\
1 / 2 \text { to } 1 \text { in. } \\
1 \text { to } 2 \text { in. } \\
1 / 2 \text { in. } \\
1 / 2 \text { in. } \\
1 / 2 \text { in. } \\
1 \text { to } 2 \text { in. } \\
1 \text { to } 2 \text { in. } \\
1 / 4 \text { in. } \\
1 / 2 \text { to } 1 \text { in. } \\
1 \text { to } 2 \text { in. } \\
1 / 4 \text { in. } \\
1 / 2 \text { to } 1 \text { in. } \\
2 \text { to } 3 \text { in. } \\
1 / 2 \text { in. } \\
1 \text { in. } \\
1 \text { to } 2 \text { in. } \\
1 / 2 \text { to } 1 \text { in. } \\
2 \text { to } 3 \text { in. } \\
1 / 2 \text { in. } \\
1 \text { to } 2 \text { in. } \\
1 \text { to } 2 \text { in. } \\
1 \text { to } 2 \text { in. } \\
1 / 4 \text { to } 1 / 2 \text { in. }\end{array}$ & 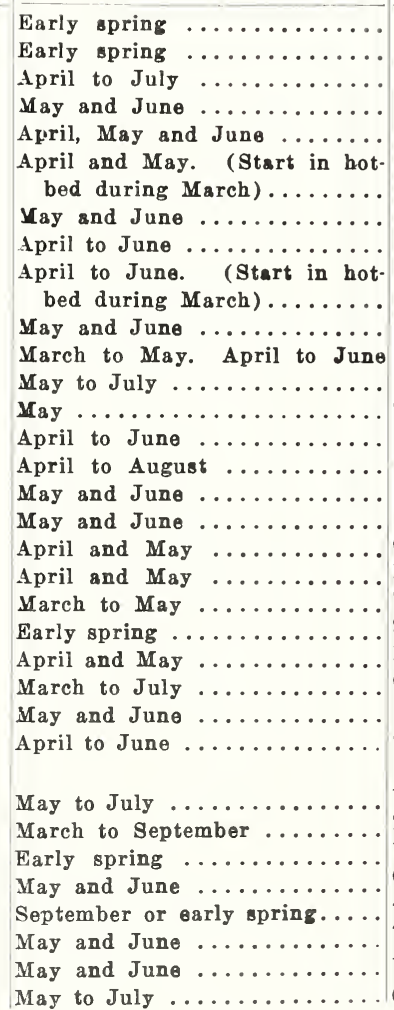 & $\begin{array}{l}3 \text { to } 4 \text { years } \\
2 \text { to } 3 \text { years } \\
40 \text { to } 65 \text { days } \\
50 \text { to } 80 \text { days } \\
90 \text { to } 120 \text { days } \\
90 \text { to } 130 \text { days } \\
90 \text { to } 130 \text { days } \\
75 \text { to } 110 \text { days } \\
100 \text { to } 130 \text { days } \\
90 \text { to } 120 \text { days } \\
30 \text { to } 40 \text { days } \\
80 \text { to } 100 \text { days } \\
90 \text { to } 110 \text { days } \\
60 \text { to } 90 \text { days } \\
60 \text { to } 90 \text { days } \\
120 \text { to } 150 \text { days } \\
100 \text { to } 120 \text { days } \\
60 \text { to } 90 \text { days } \\
130 \text { to } 150 \text { days } \\
90 \text { to } 120 \text { days } \\
90 \text { to } 120 \text { days } \\
125 \text { to } 160 \text { days } \\
60 \text { to } 90 \text { days } \\
100 \text { to } 120 \text { days } \\
80 \text { to } 140 \text { days } \\
100 \text { to } 140 \text { days } \\
20 \text { to } 40 \text { days } \\
1 \text { to } 3 \text { years } \\
60 \text { to } 80 \text { days } \\
40 \text { to } 60 \text { days } \\
70 \text { to } 90 \text { days } \\
120 \text { to } 160 \text { days } \\
60 \text { to } 80 \text { days }\end{array}$ \\
\hline
\end{tabular}

\section{TABLE SHOWING THE QUANTITY OF SEED USUALLY SOWN UPON AN ACRE}

Barley, broadcast

Beans, Dwarf, in drills

Beans, Pole, in hills

Beets, Table, in drills

Beets, Mangel-Wurzel

Buckwheat

Cabbage, in beds to transplant

Carrot, in drills

Clover, Alsike, alone

Clover, Alsike, in mixture

Clover, Crimson

Clover, Red, alone

Clover, Red, in mixture

Clover, Sweet, unhulled

Clover, White,

Clover, Lucerne or Alfalfa

Corn, Sweet, in hills

Corn, for ensilage

Cucumber, in hills

Grass, Kentucky Blue

Grass, Orchard

Grass, Red Top (Recleaned)

Grass, Timothy

Grass, Hungarian

Grass, Lawn

Melon, Musk, in hills

Melon, Water, in hills

Millet, Japanese

Mullet, Golden

Oats, broadcast

Onion, in driiss
2 to 3 bush.

$11 / 4$ bush.

10 to 12 qts.

6 lbs.

$6 \mathrm{lbs}$.

1 bush.

$1 / 4 \mathrm{lb}$.

3 to 4 lbs.

5 to $6 \mathrm{lbs}$.

2 to 4 lbs.

12 to $15 \mathrm{lbs}$.

8 to $12 \mathrm{lbs}$.

4 to $6 \mathrm{lbs}$.

25 to $30 \mathrm{lbs}$.

4 to 8 lbs.

$20 \mathrm{lbs}$.

10 qts.

$16 \mathrm{qts}$.

$2 \mathrm{lbs}$.

$42 \mathrm{lbs}$.

22 lbs.

$6 \mathrm{lbs}$.

$1 / 2$ bush.

1 bush.

$75 \mathrm{lbs}$.

2 to 3 lbs.

4 to $5 \mathrm{lbs}$.

20 lbs.

1 bush.

2 to 3 bush.

5 libs.
Onion Sets, in drills

Parsnip, in drills

Peas, Canada field, broadcast

Peas, Canada field, with oats

Peas, cow, broadcast

Peas, cow, in drills

Potatoes (Cut Tubers)

Pumpkins, in hills

Radish, in drills

Rye, broadcast

Rape, broadcast

Rape, in drills

Sage, in drills

Spinach, in drills

Squash (Bush Varieties), in hills

Squash (Running Varieties), in

$$
\text { hills }
$$

Soy Beans, broadcast

Soy Beans, in drills

Soy Beans, in drills with corn

Sunflower

Tomato, to transplant

Turnip, broadcast

Turnip, in drills

Vetch, Hairy, drilled (plus 1 bu. small grain)

Vetch, Hairy, broadcast plus 1 bu. small grain)

Vetch, Spring, plus 1 bu. small grain

Wheat, broadcast
8 bush.

$5 \mathrm{lbs}$.

120 to $150 \mathrm{lbs}$

75 to $90 \mathrm{lbs}$

60 to $75 \mathrm{lbs}$

45 to $60 \mathrm{lbs}$.

10 bush.

4 lbs.

8 lbs.

$11 / 2$ bush.

6 to $8 \mathrm{lbs}$.

4 to $5 \mathrm{lbs}$.

8 lbs.

10 lbs.

$2 \mathrm{lbs}$.

$4 \mathrm{lbs}$.

60 to $90 \mathrm{lbs}$.

30 to $45 \mathrm{lbs}$.

15 to $20 \mathrm{lbs}$.

6 to $8 \mathrm{lbs}$.

$1 / 4 \mathrm{lb}$.

2 lbs.

$11 / 2 \mathrm{lbs}$.

40 to $50 \mathrm{lbs}$.

50 to $60 \mathrm{lbs}$.

80 lbs.

1 t/ to 2 bush. 


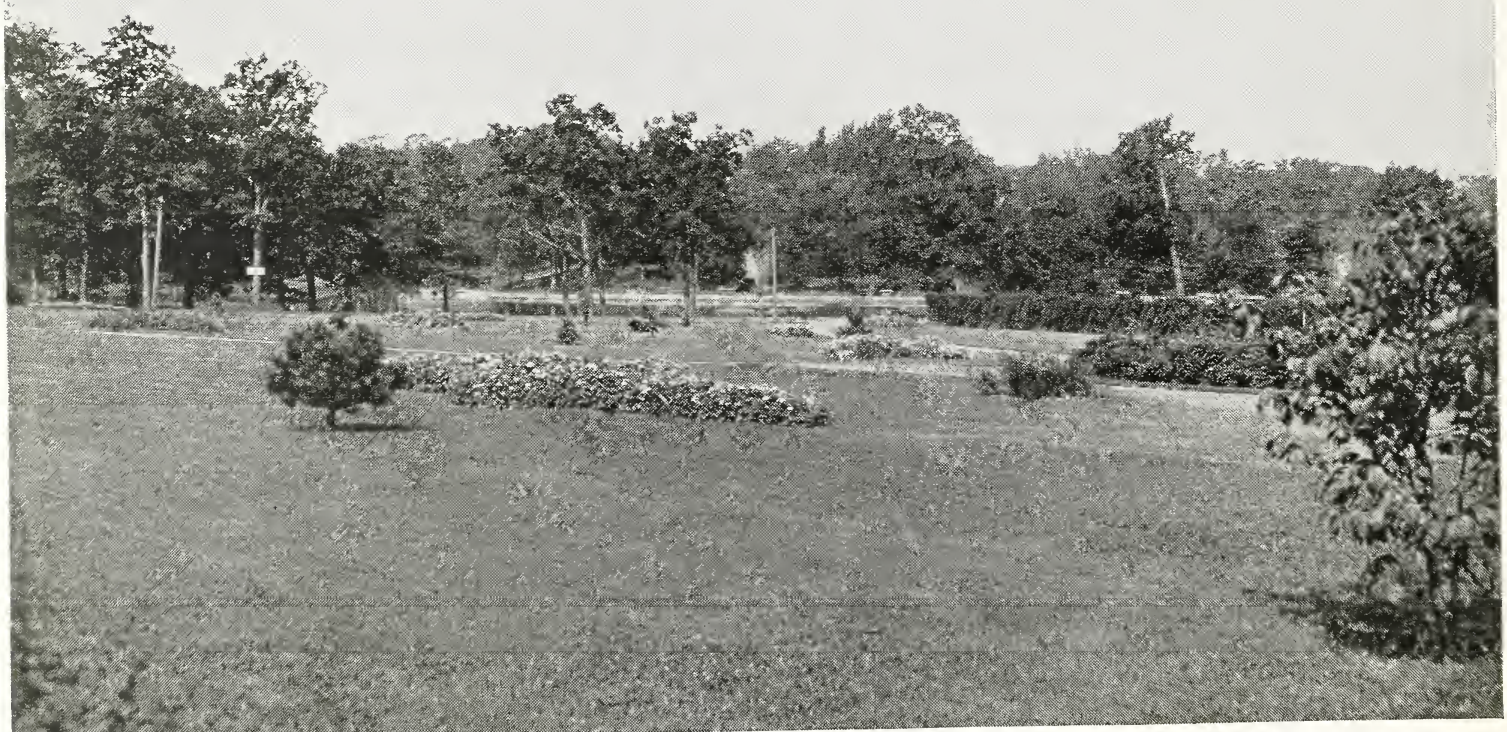

Deering's Oaks Park, Portland, Maine 